\title{
An innovative
}

methodological approach for the analysis of the effects of urban interventions on property prices

Felicia Di Liddo*, Pierluigi Morano**, Francesco Tajani***, Carmelo Maria Torre ${ }^{* * * *}$ keywords: urban redevelopment, property assets enhancement, urban quality, maket values, property prices, real estate market

\section{Abstract}

The evaluation of the effects that an urban intervention generates on the area in which it is realized, and more generally on the city-system, plays a central role in the definition of its effectiveness, as it measures the effects that may derive from its implementation in terms of improving the quality level of the natural and built environment. The present research intends to propose and test a methodological and operational approach to evaluate, with quantitative indicators, the effects that an urban redevelopment initiative can have on property prices. In particular, the aim of the work concerns the development of a procedural protocol articulated into clear and replicable phases, in order to support the analysis of the urban transformation effects. The protocol is applied to four redevelopment projects currently in progress, located in four municipal trade areas in the city of Bari (Southern Italy). For each urban area, a sample of two hundred residential properties sold in the period 2017-2019 has been collected. The implementation of a genetic algorithm has allowed the definition of the econometric price function, able of identifying the set of variables - intrinsic and extrinsic - which, in each of the four intervention areas, contributes to the formation of property prices in the "ante-project" situation. The analysis of the effects of urban redevelopment in terms of variation of the urban quality has been carried out. Through an exogenous approach based on the interview of experts and community individuals, the values of the factors related to the urban quality following the implementation of the projects have been determined again ("post-project" situation). By inserting the new values into the econometric price functions already found, the market values of the post-project situation have been estimated. The comparison between ex ante and ex post market values shows the increase in property prices following the redevelopment initiative and allows to quantify it, confirming the full consistency with the expected empirical trends. 


\section{INTRODUCTION}

Urban area redevelopment policies are among the most important issues in the debate on the recovery from the economic crisis triggered in 2007 by the American subprime and still in progress.

In this sense, the degraded or abandoned areas, currently considered as urban voids and places of social unrest concentration, are starting to be seen as an opportunity for the economic cities development, as possible containers of functions in accordance with the needs and the community demands.

The redevelopment processes of more or less extensive portions of the territory or buildings, operate on the settlements system and produce effects on the entire city, determining economic and social externalities that are reflected in its image (Agnoletti et al., 2014). The quantification of these impacts plays an important role to guide the decision-making processes of public and private investors.

In the recent years, the need to evaluate and measure in social, economic and environmental terms - the effects generated by territorial transformation interventions has been occurred with increasing intensity (Rosato, 2017).

The notion of "urban quality", intended as a goal to be pursued in the context of settlement processes and territorial dynamics, is strongly debated by urban planners, architects, economists, environmentalists, anthropologists and sociologists. The "quality" of an area is unavoidably linked to the community quality of life, as it influences the well-being of citizens who live it, in terms of health and psychological tranquility. The relationship between the quality level of the urban environment and the social, physical, mental and economic well-being of the inhabitants (Ludlow, 2009) demonstrates the importance of enhancing public spaces, often characterized by degradation conditions or in an abandonment state, through strategic actions aimed at achieving a high quality standard.

The issue of disposal and functional reconversion of degraded areas and abandoned existing property assets has been widely dealt with in the reference literature and in the urban planning practice (Adair et al., 2000; Kort et al., 2011; Bottero et al., 2019; Morano et al., 2020). These assets have a fundamental role in:

i) redefining the structure of a wider territorial system,

ii) increasing the quality of the built environment,

iii) growing the competitiveness of the city,

iv) stimulating investments,

v) i mproving and enriching the urban offer.

In the practice, the selection of the projects of an investment program, when it is not guided by political reasons or by emergencies related to the funding deadlines, is performed by evaluation tools that allow to verify the feasibility of the intervention from the point of view of all the subjects involved in the initiative and to better balance the interests of the parties. The financial analysis (e.g. Cost-Revenue Analysis), carried out exclusively from the point of view of the private entity (operation investor), concerns the verification of the convenience of the project "itself", i.e. its ability to repay the debt capital and to generate a profit for the entrepreneur (Kishore, 1996; Helfert et al., 2001; Herbohn et al., 2002; French et al., 2005). Economic analyis (e.g. Cost-Benefit Analysis) extends the point of view of the assessment to the community, and compares the effects generated by the implementation of the intervention in terms of positive and negative effects (Lichfield, 1962; Marglin, 1963; Sassone et al., 1978; Layard, 1994; Boice, 1999; Brzozowska, 2007; Gabrielli et al., 2016). Given the spread difficulty of translating the economic effects on the territory into monetary terms, a growing interest in multi-criteria techniques, which allow to take into account the multidimensional nature of urban plans and projects assessments and to simultaneously pursue multiple objectives, by defining a compromise solution between the different economic, social and environmental issues, should be highlighted (Rosato, 1998; Beinat et al., 1998; Figueira et al, 2005; Munda, 2008; Nijkamp et al., 2013; Farinelli et al., 2016; Guarini et al., 2017; Guarini et al., 2018; Fregonara et al., 2019).

\section{AIMS}

The present research concerns the framework outlined and aims at the systematic analysis of the effects of urban interventions on property prices.

The aim relates the development of a methodological approach by which it is possible to evaluate, in the ex ante assessment phase and in quantitative terms, the effects that an urban intervention could generate on property prices. In particular, the study focuses on two questions:

- the first concerns the notion of "urban quality";

- the second relates to the relationship between recovery projects, urban quality and property prices.

Specifically, the research intends to define and test $i$ ) an innovative model of urban quality assessment, ii) a methodological-operational approach that allows the evaluation of the effects generated by urban interventions on property prices.

The methodological-operational approach developed intends to be an original tool to support the decisionmaking processes of urban planning, the redevelopment of property assets and/or the functional reconversion of 
An innovative methodological approach for the analysis of the effects of urban interventions on property prices

collective public spaces. The approach allows the assessment of the intervention effects on urban quality and on property prices and, in the presence of different project solutions, the definition of a list of temporal priorities based on the impacts that each project solution generates on the reference local context. The tool, to be encoded in a specific procedural protocol structured in stages with clear and replicable contents, can be used by Public Administrations and/or, in the case of publicprivate partnership, by private investors, in order to identify urban portions on which higher convenience to intervene is defined.

The paper is organized as follows. In Section 3 the notion of "urban quality" is investigated: after a brief overview of the main aspects that characterize the concept, the model that is proposed for assessing the urban space quality is illustrated. In Section 4 a procedural protocol divided into phases, to be implemented for the evaluation of the effects of urban interventions on property prices, is explained. In Section 5 the protocol is applied to a case study relating to the city of Bari: the urban interventions are specified and the variables of the model are outlined; the econometric technique used to define the function of the price is illustrated. Furthermore, the technique is implemented and the results obtained in the "anteproject" situation are shown; the analysis of the effects in the "post-project" situation is developed through $i$ ) the quantification of the variation of the urban quality level following the projects implementation, ii) the determination of the new property prices, iii) the comparison of the estimated prices in the "ante-project" and "post-project" situations; finally, the results obtained in terms of the initiatives effects on property prices are summarized. Finally, in Section 6 the conclusions of the work and the future perspectives of the research are discussed.

\section{THE QUALITY OF URBAN SPACE}

The relationship between man, natural environment and man-made one, is complex. In the social sciences, numerous studies have dealt with the issue of individual and collective well-being, not only in terms of economic wealth, but also of quality of life ones. In this regard, the growing interest in the urban economy for this question derives from the influence that the quality of life has on the increase and competitiveness of cities.

The urban quality notion includes an articulated characterization that reflects the nature of a complex system such as the city.

"Quality" is a gradual relative value, it varies according to the users, the places and their different and specific uses, but, above all, it changes with the times, culture, customs and tastes. It does not constitute a feature whose presence can be verified, as it does not show itself in absolute and tangible terms. The judgment on the quality of a place is expressed by the users of this area and is connected to the cultural, social and economic aspects of the reference population, their history and identity. There is no univocal and generally valid criterion able to measure the urban quality, as the evaluation of the place quality, as well as the well-being or quality of life, are strongly linked to individual perceptions.

The urban environment quality does not derive exclusively from the compliance with the forecasts of urban planning tools, especially if these are not supported by a planning phase able to guarantee the integration of all the population needs. Moreover, it does not derive from merely compliance with urban planning standards, since it is not enough to modify the quantitative relationships among the functions to automatically assurance their use by all inhabitants. Furthermore, the presence of services in a territorial system is not enough to ensure a high level of urban quality, because the correct proportionality, the balanced distribution and the accessibility of services must also be guaranteed. In the same way, it would be reductive to identify urban quality only with the "good architecture" of buildings, because it loses value if it does not refer to a relationship with its intended use and with the context in which it is included.

The question of urban quality has now a high relevance in the context of urban interventions planning, constituting a fundamental objective in the territory governance aimed at social development and economic growth of cities.

\subsection{The urban quality indicators}

In the last years, different researches have attempted to explain the urban quality multidimensional nature, and to quantify it for empirical research purposes. These studies are based on the heuristic assumption according to which the social and physical environment influences the users well-being, generating a sense of satisfaction (or dissatisfaction) with that space. This question is widely dealt with in the psychological disciplines context. On the other hand, Economists focus mainly on the physiopsychological relationship, in order to investigate the impact of it on the perception of the different urban areas factors and on the behavior of each subject (Lambiri et al., 2007). For example, Rogerson (1999) has analyzed the link between the quality of life and the settlement choices made by companies and individuals, highlighting how the life quality level can be used to promote a location to attract potential investors. Similarly, Hall (1995) has identified quality factors that could contribute to improve urban development.

In Shin et al. (2003) the two dimensions - objective and subjective - of the life quality have been considered as different identities. The first refers to manifest behavior and conditions on observable factors, such as the 
economic wealth of a city, the health of its inhabitants, etc., assessed on the basis of the frequency with which the phenomenon occurs, often aggregated in synthetic indices to carry out national and international comparisons - i.e. the economic wealth of a country measured in GDP terms, the average longevity of the population, the education level, the average level of illiteracy, unemployment, etc. (D'Acci, 2007, 2009). Nevertheless, the objective indicators may not accurately reflect the perception of well-being by the places users, since well-being is a complex emotion to be defined and, consequently, to be quantified (Das, 2008). The second component of the life quality - the subjective one - refers to the psychological dimension of the users and to their satisfaction level. This component aims to the individual assessment of the life quality conditions, in terms of perceived well-being and livability of the place to live and work, through the use of indicators that reflect moods and perceptions related to the job accomplishment level, the ambitions fulfillment, the psychological tranquility level, the satisfaction of primary needs, the gratification at individual and collective level.

Although establishing a close relationship, the well-being two dimensions - objective and subjective - are not directly related and, therefore, the increase in one does not systematically represent a growth in the other one.

The question of urban quality plays a central role in territorial regeneration policies aimed at the "realization" of accessible, safe, aesthetically pleasing, clean and adequately comfortable urban places.

The progressive transfer of the production facilities from central areas to peripheral ones or suburbs of the cities has made available urban spaces with strategically relevant locations to redesign the distribution of functions on territory and to raise the perceived quality level.

Although there is no universally shared and generalizable definition of "urban quality", the hierarchical and multidimensional aspect of this notion is known, characterized by different attributes which, in turn, are declined by more specific aspects (D'Acci, 2014). These factors refer to environmental quality, air quality, the presence of green spaces, work, social conditions, the architecture quality, the pedestrian areas presence, etc. and they can be assessed using a) monetary approaches (hedonic price method, willingness to pay, cost-benefit ratio, positional value), b) subjective approaches (life satisfaction and perceived personal well-being level), c) quantitative approaches (analysis of the urban amenities and their distribution in the urban area).

The quality of the urban environment cannot be included into a unique category whose presence (or absence) can be detected, but it depends on a complex of natural, physical-spatial, functional, anthropic-social and historical-cultural factors that contributes, as far as possible, to its definition (Agnoletti et al., 2014).
Many researchers have tried to investigate and to assess the quality of urban life notion. Richards et al. (2007) have studied the factors to improve the life quality of the inhabitants in informal housing, and the main constraints to raise the life quality in South Africa. Clark and Kahn (1988) have estimated the willingness to pay for urban cultural services such as museums, theaters, dance and music venues, zoos, concluding that the marginal benefits of cultural assets are between $\$ 85$ and $\$ 54.9$ million respectively for an additional theater and zoo. With reference to eight cities located in six Latin American countries, Lora et al. (2010) have identified the criteria for establishing the priorities of the political actions aimed at improving social well-being, in order to determine indicators to assess the impact of new structures and new public services on life quality and housing prices.

\subsection{A model for the assessment of urban quality}

The procedure proposed for the assessment of urban quality involves the disaggregation of the notion into its components. Each one is then articulated and measured using appropriate indicators. It should be noted that this approach for the assessment of urban quality must take into account qualitative and subjective aspects, as well as quantitative and objective elements.

Furthermore, the model developed does not intend to reach the identification of a global and synthetic index of urban quality, but its main aim is to analyse the different aspects of quality.

Therefore, the model proposed aims to quantify the urban quality indicators related to the status quo situation and it allows to assess the expected quality variation following an urban intervention.

The articulation of the developed phases borrows the logical breakdown from the Audis 2008 Urban Regeneration Charter (AA.VV., 2010, AUDIS, 2008, 2012)

Table 1 shows the six components of urban quality identified:

Table 1 - Components of urban quality Author elaboration

ARCHITECTURAL QUALITY

PLANNING QUALITY

ENVIRONMENTAL QUALITY

LANDSCAPE QUALITY

QUALITY OF THE PUBLIC SPACE

SOCIAL QUALITY 
An innovative methodological approach for the analysis of the effects of urban interventions on property prices

The indicators selected in the present research for the quantification of urban quality components can be classified as follows:

- Objective indicators: they refer to tangible and measurable quality aspects. With reference to each component, the objective indicators aim to verify the presence (or absence) of elements to evaluate the urban quality and to assess $i$ ) the distances from particular qualifying or dequalifying elements and ii) the level of a specific quality aspect based on official data.

- Type 1 subjective indicators: they refer to scores assigned by teams of sociologists, landscapers, architects, environmental experts, etc., in order to evaluate the capacity of an urban area to provide adequate quality standards to the community. For each indicator of this category, the judgments of "competent" subjects based on verbal scales (excellent, good, scarce) are transposed into numerical values included in scales of scores previously established.

- Type 2 subjective indicators: they aim to assess aspects of perceived urban quality. With reference to the research carried out by Bonaiuto et al. (2010), the evaluation of this category of indicators is expressed through numerical judgments assigned by a sufficiently representative sample of the area users with reference to the subjective aspects of urban quality, considering the opinion of the community and/or of the urban area regular and occasional visitors and transforming the judgments in quantitative terms. The conversion of personal subjective perceptions in numerical terms involves the formulation of appropriate questionnaires and/or surveys to be submitted to a sample of individuals. The category of "type 2 - subjective indicators" allows not to limit the process of assessing urban quality exclusively to compliance with urban planning standards and/or minimum thresholds set at a general level, but to explain the personal perceptions of the subjects who "live" in a urban space and to report them in the synthetic and global judgments form. In the present research, a questionnaire has been introduced consisting of a set of verbal expressions (item), referring to the topic to evaluate. The items are characterized by an affirmative or negative sense. The evaluation is expressed in quantitative terms: to each expression the interviewees can answer through a numerical gradation of the judgment in a predetermined values range (between " 0 " and " 5 "), where the value " 0 " identifies a total disagreement with the affirmation of the item, whereas the value " 5 " indicates a condition of total agreement. Within the same quality component to be assessed, the presence of positive and negative phrases, although complicating the questionnaire compilation by the interviewees, allows to maximize the answers consistency.

Following the different items evaluation, the data aggregation phase is carried out using calculation tables with which it is possible to determine the average values of each aspect of the perceived urban quality. The operation should take into account the presence in the questionnaire of items with a positive sense and others with a negative sense. For example, according to the mentioned research by Bonaiuto et al. (2010), positive items are considered for the relative values recorded during the questionnaire administration, whereas the negative ones are re-evaluated as the difference between the maximum value and the score attributed by the interviewee. For the present analysis, the questionnaire has been borrowed from the conclusions of Fornara et al. (2010), in order to define the "type 2 - subjective indicators" for the evaluation of the perceived urban quality (item). For each of the six urban quality components, in Table 2 the proposed indicators are shown.

Table 2 - Indicators proposed for the assessment of the urban quality components

\begin{tabular}{|c|l|c|c}
\hline COMPONENTS & \multicolumn{1}{|c|}{ OBJECTIVE INDICATORS } & \multicolumn{1}{c}{ TYPE 1 SUBJECTIVE INDICATORS } \\
$\begin{array}{c}\text { ARCHITECTURAL } \\
\text { QUALITY }\end{array}$ & $\begin{array}{l}\text { Distance of the property from the nearest architectural } \\
\text { element [kilometers it takes to walk to it] }\end{array}$ & $\begin{array}{l}\text { Maintenance } \\
\text { the buildings facades adjacent to the } \\
\text { property }\end{array}$ \\
\hline PLANNING & $\begin{array}{l}\text { Distance of the property } \\
\text { Q from the nearest bus stop [kilometers it takes to walk } \\
\text { to it] } \\
\text { from the nearest highway [kilometers it takes to get } \\
\text { there by car] } \\
\text { from the nearest railway station [kilometers it takes to } \\
\text { walk to it] } \\
\text { from the nearest subway [kilometers it takes to walk to } \\
\text { it] } \\
\text { from the nearest public parking [kilometers it takes to } \\
\text { walk to it] }\end{array}$ & Territory functional mix level \\
\hline
\end{tabular}

Follows Table 2 - Indicators proposed for the assessment of the urban quality components 
Follows Table 2 - Indicators proposed for the assessment of the urban quality components

\begin{tabular}{|c|c|c|}
\hline COMPONENTS & OBJECTIVE INDICATORS & TYPE 1 SUBJECTIVE INDICATORS \\
\hline $\begin{array}{l}\text { ENVIRONMENTAL } \\
\text { QUALITY }\end{array}$ & $\begin{array}{l}\text { Distance of the property from the nearest urban green } \\
\text { space [Kilometers it takes to walk to it] } \\
\text { Air pollution level in the area [average daily concentration } \\
\text { of PM10, PM2.5, NO2, SO2 and O3] }\end{array}$ & $\begin{array}{l}\text { Maintenance conditions of the nearest } \\
\text { urban green space } \\
\text { Road private and public vehicular traffic } \\
\text { level } \\
\text { Overall hygiene level in the urban area }\end{array}$ \\
\hline $\begin{array}{l}\text { LANDSCAPE } \\
\text { QUALITY }\end{array}$ & $\begin{array}{l}\text { Distance of the property from the landmark for the local } \\
\text { community (architectural and landascape emergence) } \\
\text { [kilometers it takes to walk to it] }\end{array}$ & $\begin{array}{l}\text { Ability of the landscape to integrate with } \\
\text { the urbanized space }\end{array}$ \\
\hline $\begin{array}{l}\text { QUALITY OF THE } \\
\text { PUBLIC SPACE }\end{array}$ & $\begin{array}{l}\text { Presence of security threats in the area [Number of } \\
\text { crimes recorded in the area in the last year] }\end{array}$ & $\begin{array}{l}\text { Maintenance conditions of the public } \\
\text { spaces adjacent to the property }\end{array}$ \\
\hline SOCIAL QUALITY & $\begin{array}{l}\text { Urban scale services } \\
\text { Distance of the property } \\
\text { - from the nearest public library [[kilometers it takes to } \\
\text { walk to it] } \\
\text { - from the nearest public sports center [[kilometers it } \\
\text { takes to walk to it] } \\
\text { - from the nearest museum/theater/cinema [[kilometers } \\
\text { it takes to walk to it] } \\
\text { - from the nearest public university [[kilometers it takes } \\
\text { to walk to it] } \\
\text { Public educational and cultural services } \\
\text { Distance of the property } \\
\text { - from the nearest public kindergarten [kilometers it } \\
\text { takes to walk to it] } \\
\text { - from the nearest public primary school [kilometers it } \\
\text { takes to walk to it] } \\
\text { Commercial services } \\
\text { Distance of the property } \\
\text { - from the nearest supermarket [kilometers it takes to } \\
\text { walk to it] } \\
\text { - from the nearest post office [kilometers it takes to walk } \\
\text { to it] } \\
\text { - from the nearest bank [kilometers it takes to walk to it] } \\
\text { Health and assistance services } \\
\text { Distance of the property from the nearest nursing home } \\
\text { [kilometers it takes to walk to it] } \\
\text { Public structures for the healthcare in the area [Number] }\end{array}$ & $\begin{array}{l}\text { Urban scale services } \\
\text { Quality level of urban-scale services in the } \\
\text { area } \\
\text { Public educational and cultural services } \\
\text { Quality level of public educational and } \\
\text { cultural services in the area } \\
\text { Commercial services } \\
\text { Quality level of commercial services in the } \\
\text { area } \\
\text { Health and assistance services } \\
\text { Quality level of health and assistance } \\
\text { services in the area }\end{array}$ \\
\hline
\end{tabular}

\section{A PROTOCOL FOR THE ANALYSIS OF THE EFFECTS OF URBAN INTERVENTIONS ON PROPERTY PRICES}

The identification of the social, functional, economic, environmental effects that can be generated by an urban transformation initiative, constitutes a useful operation to guide the territory government decisions. In this sense, the leading role provided by the Appraisal and Valuation in the urban and territorial transformation processes should be appropriate in all project phases (Agnoletti et al., 2014).

In the framework outlined, a procedural protocol for the analysis of the effects of urban interventions on property prices is proposed. This procedure is configured as an orderly and sequential succession of steps to be performed, and it aims to provide a methodologicaloperational practice able of explaining an urban redevelopment project effects.

The proposed operational tool intends to be a generally valid theoretical model that can be used by Public Administrations or by private investors in any territorial context, in order to support the decision-making processes relating to a urban intervention. In fact, this model is independent from the spatial and temporal conditions of the specific case study, and its correct use depends exclusively on the quantity and quality of the available data. In Table 3 the protocol is reported: for each phase, the main actions to be performed are illustrated. 
An innovative methodological approach for the analysis of the effects of urban interventions on property prices

Table 3 - Protocol for the analysis of the effects of urban interventions on property prices

\begin{tabular}{|c|c|c|}
\hline PHASE 1 & Study of the urban intervention. & $\begin{array}{l}\text { 1.1 Analysis of the intervention in the } \\
\text { municipal territory context. } \\
\text { 1.2 Explanation of the main functions } \\
\text { planned and definition of the project } \\
\text { general aims. }\end{array}$ \\
\hline PHASE 2 & $\begin{array}{l}\text { Data collection in the ante-project } \\
\text { situation. }\end{array}$ & $\begin{array}{l}\text { 2.1 Identification of a properties sample, } \\
\text { with known selling price and } \\
\text { characteristics, located in the } \\
\text { municipal territory or distributed in } \\
\text { the different homogeneous trade } \\
\text { areas of the city. } \\
\text { 2.2 Identification of the intrinsic and } \\
\text { extrinsic variables that influence the } \\
\text { properties market value and } \\
\text { selection of the relative assessment } \\
\text { procedure (score scale, distance, } \\
\text { surface, time/duration, etc.). } \\
\text { 2.3 Assessment of the urban quality level } \\
\text { in the current state (ante-project } \\
\text { situation). } \\
\text { 2.4 Construction of the database relating } \\
\text { to the current state by identifying the } \\
\text { values of each variable for each } \\
\text { property of the study sample. }\end{array}$ \\
\hline PHASE 3 & $\begin{array}{l}\text { Application of the econometric } \\
\text { technique in the ante-project situation. }\end{array}$ & $\begin{array}{l}\text { 3.1 Definition of the function that links } \\
\text { selling prices and the intrinsic and } \\
\text { extrinsic factors that contribute to } \\
\text { their formation in the current } \\
\text { situation. }\end{array}$ \\
\hline PHASE 4 & $\begin{array}{l}\text { Analysis of the functional links obtained } \\
\text { in the ante-project situation. }\end{array}$ & $\begin{array}{l}\text { 4.1 Determination of the marginal } \\
\text { contribution of each variable } \\
\text { (intrinsic and extrinsic) to examine } \\
\text { the percentage incidence of each } \\
\text { variable on the property prices in the } \\
\text { ante-project situation. }\end{array}$ \\
\hline PHASE 5 & $\begin{array}{l}\text { Assessment of the urban quality level in } \\
\text { the post-project situation. }\end{array}$ & $\begin{array}{l}\text { 5.1 Application of the proposed model } \\
\text { for the urban quality assessment with } \\
\text { reference to the hypothetical future } \\
\text { state (post-project situation) in order } \\
\text { to evalue the modification of the } \\
\text { extrinsic variables values. }\end{array}$ \\
\hline PHASE 6 & $\begin{array}{l}\text { Determination of the new property } \\
\text { prices expected in the post-project } \\
\text { situation. }\end{array}$ & $\begin{array}{l}\text { 6.1 Replacement in the function } \\
\text { identified through the step } 3.1 \text { of the } \\
\text { "new" extrinsic variables values for } \\
\text { which, following the new functions } \\
\text { proposed, a variation is expected. }\end{array}$ \\
\hline PHASE 7 & $\begin{array}{l}\text { Comparison of the estimated values in } \\
\text { the ante and post-project situations. }\end{array}$ & $\begin{array}{l}\text { 7.1 For each municipal trade area into } \\
\text { which the city territory is divided, } \\
\text { comparison between the estimated } \\
\text { values relating to the current state } \\
\text { and the estimated values referring to } \\
\text { the post-project situation. The aim } \\
\text { concerns the determination of possi- } \\
\text { ble percentage increases or } \\
\text { decreases in the property prices } \\
\text { connected to the project } \\
\text { implementation. }\end{array}$ \\
\hline
\end{tabular}

Follows Table3 - Protocol for the analysis of the effects of urban interventions on property prices 
Follows Table 3 - Protocol for the analysis of the effects of urban interventions on property prices

\begin{tabular}{l|l|l} 
PHASE 7 & $\begin{array}{l}\text { Comparison of the estimated values in } \\
\text { the ante and post-project situations. }\end{array}$ & $\begin{array}{l}7.2 \text { Identification and illustration of the } \\
\text { possible reasons for the increases } \\
\text { and/or decreases assumed in order } \\
\text { to validate their reasonableness and } \\
\text { congruence. }\end{array}$ \\
\hline PHASE 8 & Summary of the results obtained. & $\begin{array}{r}8.1 \text { Overall assessment of the possible } \\
\text { effects expected, not only with } \\
\text { regards to variations in property } \\
\text { prices, but also in terms of raising the } \\
\text { urban, } \\
\text { quality level associated with the } \\
\text { transformation intervention. }\end{array}$
\end{tabular}

\section{AN APPLICATION OF THE ASSESSMENT PROTOCOL}

With reference to four urban interventions currently in progress in the city of Bari (Puglia region capital), the assessment protocol has been implemented.

Each intervention is located in one of the four municipal trade areas (central, semicentral, peripheral, suburban) considering the geographical distribution developed by the Real Estate Market Observatory (OMI) of the Italian Revenue Agency (http://www.agenziaentrate.gov.it/).

The urban interventions selected for the analysis are different by location and type. In fact, they concern respectively:

- a property enhancement project to be implemented in the central trade area that concerns the realization of the "Polo del Contemporaneo";

- a redevolpment initiative to regenerate "via Giovanni Amendola" in the semicentral trade area;

- the regeneration of the "San Girolamo" waterfront in the peripheral trade area;

- the recovery and improvement of the "Giovanni Paolo II" Park in the San Paolo district for the suburban trade area.

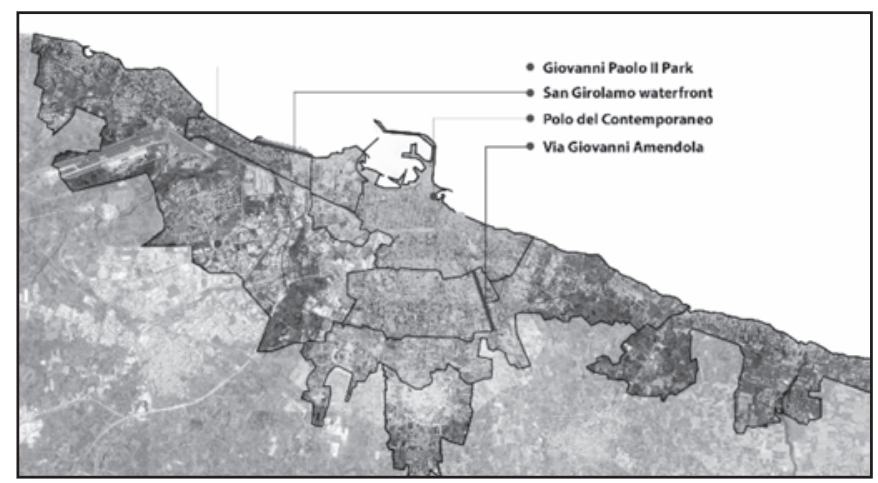

Figure 1 - Localization of the urban interventions examined
Fig. 1 shows the four interventions position in the municipal trade areas of the city of Bari.

\subsection{Description of the case study}

\section{Intervention 1. The realization of the "Polo del Contemporaneo"}

\section{Description of the current state}

The central location of the Margherita Theater, of the former Fish Market building and of the Sala Murat - the three buildings of the "Polo del Contemporaneo" - is strategic towards the historic center and, more generally, the whole city.

Built between 1912 and 1914 and subject to protection by the Superintendency of Monuments, the Margherita Theater is one of the historical theaters of the city of Bari. Until 2009 on the Theater static and external facades restauration interventions have been carried out, relating to the sea foundations and supporting structures consolidation, the fixtures replacement and the foyer decorative scheme renovation.

The former Fish Market building (Fig. 2) is a compact two-

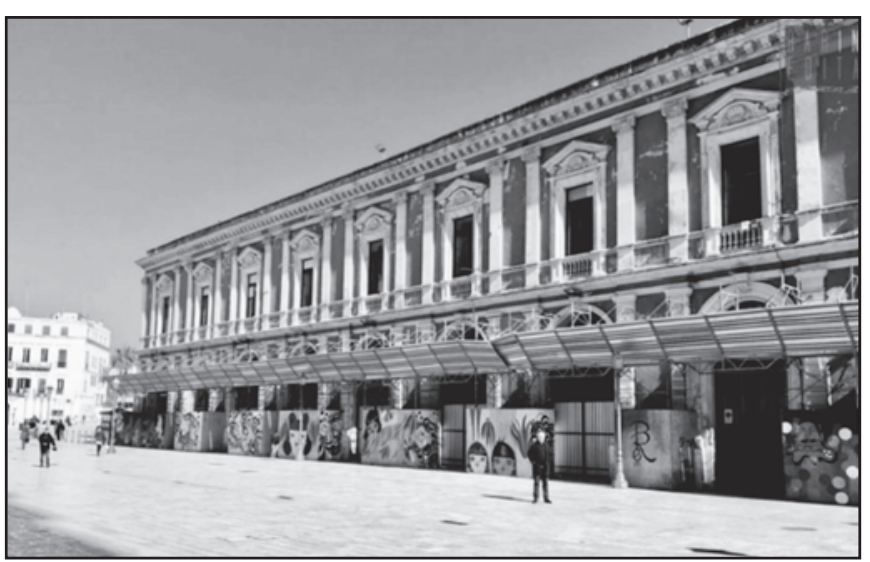

Figure 2 - The former Fish Market building - current state 
An innovative methodological approach for the analysis of the effects of urban interventions on property prices

story volume, marked by an orderly horizontal and vertical score. From the early 1900 s until the 1990s, the building round floor hosted the fish market, whereas the upper floor was the municipal police headquarters. In the recent years, the property has been at forst used as a farmers' market and then as a bazaar for clothes, leatherwear, and other goods.

Entitled to Gioacchino Murat, the Sala Murat traces the older Meat Market structure, i.e. the first public property in the city of Bari that was built in 1817 and was demolished for safety reasons (as it was strongly crumbling), after the Second World War. The current building is used as an exhibition space.

\section{The redevelopment project}

Signed by the Territorial Enhancement Agreement between the Municipality of Bari, the Puglia Region and the Ministry of Cultural Heritage and Activities and Tourism, the "Polo del Contemporaneo" project (Figure 3) aims to constitute a new multidisciplinary cultural hub of the city, as a regional, national and international tourism attraction.

The three buildings of the Polo will become the venue for events related mainly to modern and contemporary art.

Currently, on Margherita Theater and on the former Fish Market recovery and enhancement interventions are carried out. In particular, the functional recovery of the Margherita Theater intends to restore the building to its old function as a cluster able of hosting contemporary and musical art events.

The former Fish Market redevelopment project involves the building functional conversion, by the realization of a typical food and wine market and artistic local products, on the model of the Spanish markets, on the ground floor; an exhibition space for contemporary arts, laboratories, ateliers to rent, suites for artist residences, Polo del Contemporaneo offices on the first floor; finally,

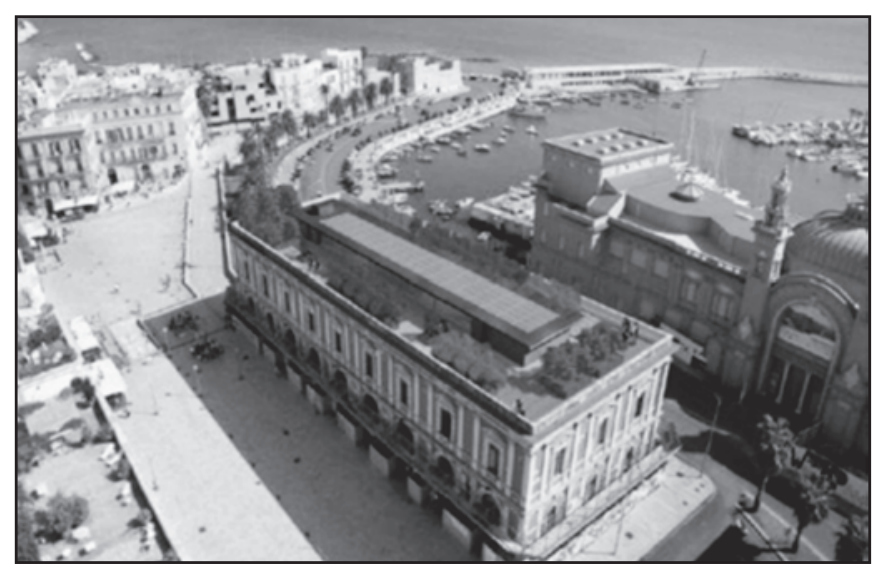

Figure 3 - The former Fish Market - project situation. On the right the Margherita Theater the terrace will be transformed into a roof garden, or a green space organised as an urban garden, to host art events, such as vernissage, inaugurations and previews.

\section{Intervention 2. The redevelopment of "via Giovanni Amendola"}

Description of the current state

Approximately 3 kilometers long and constantly congested, "via Giovanni Amendola" (Fig. 4) is one of the most important road of entry and exit from the city of Bari.

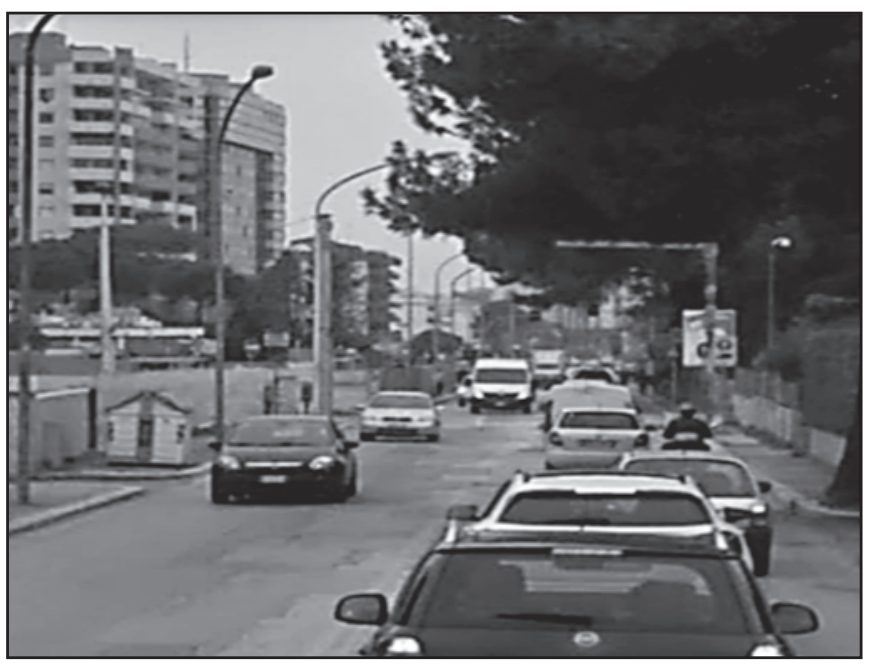

Figure 3 - The former Fish Market - project situation. On the right the Margherita Theater

\section{The redevelopment project}

The project involves the widening of "via Giovanni Amendola". In particular, the intervention concerns the road section between via Conte Giusso and via Omodeo, for a length of about 1.1 kilometers. The roadworks include: the widening of the street track with two lanes in each direction and central traffic island; the construction of three roundabouts at viale Einaudi, via Laforgia and via Hahnemann and new sidewalks; the introduction of trees and new pedestrian crossings on the central traffic island and the traffic lights removal (Fig. 5). In brief, the intervention aims to create a more sustainable and efficient urban road, also thanks to the inclusion of new urban furniture elements able to renovate the road image.

\section{Intervention 3. The regenerationt project of the "San Girolamo" waterfront}

Description of the current state

Located in the homonymous district, the "San Girolamo" waterfront extends for one kilometer. Since the late 


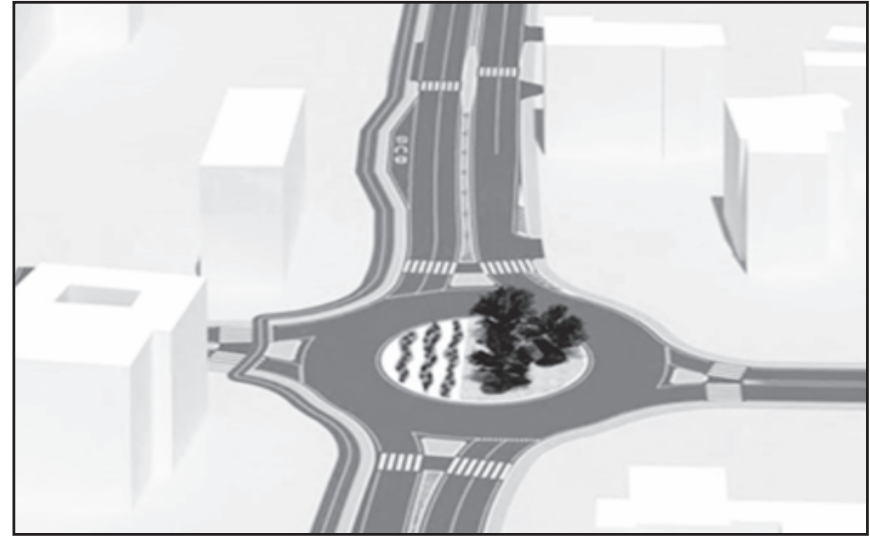

Figure 5 - "Via Giovanni Amendola" - project situation

1980s, the imposing residential building development in the urban area, has led to a significant increase in congestion phenomena, without solving the area marginality caused by the absence of an adequate infrastructure system, in terms of viability and services (Fig. 6).

With reference to the neighborhood and to the area overlooking the coast, there is a relevant demand for public services not satisfied, above all due to the lack of collective spaces such as "places for socializing".

Currently the commercial intended use located on the buildings ground floors along the coastline are often unused and the promenade is considered exclusively as a fast crossing on the edge rather than as a service axis of the neighborhood. This phenomenon contributes to emphasize the waterfront marginality with respect to the neighborhood internal area.

\section{The redevelopment project}

The redevelopment intervention of the "San Girolamo"

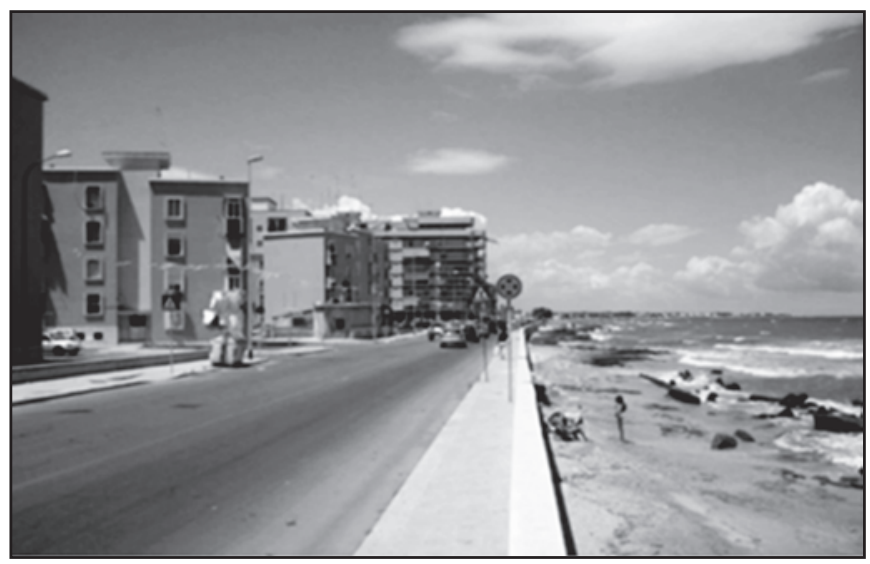

Figure 6 - "San Girolamo" waterfront - current state waterfront provides for the recovery and its functional and landscape transformation. The intervention aims to determinate a new landscape and environmental configuration overlooking the sea and new modalities for the spaces uses, with new ways of using the spaces and to involve the economic and social sectors of the neighborhood.

The waterfront redevelopment (Fig. 7) provides for its pedestrianization with the creation of an "square on the sea" of $8,000 \mathrm{~m}^{2}$ on two levels, with about 600 seatings in front of the sea, and the introduction of new urban functions, i.e. service activities, places for leisure, sport, swimming and social events.

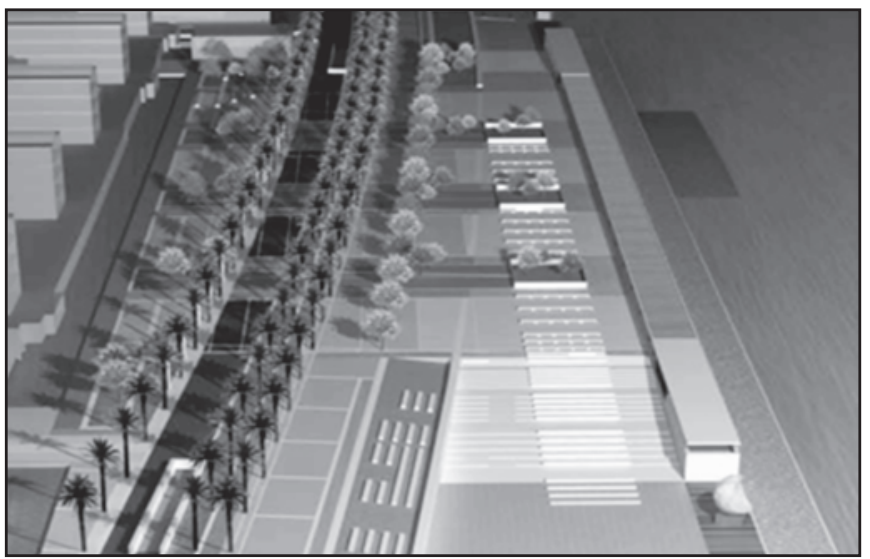

Figure 7 - "San Girolamo" waterfront - project situation

\section{Intervention 4. The recovery project of "Giovanni Paolo II"Park in the San Paolo district}

\section{Description of the current state}

The "Giovanni Paolo II" Park constitutes a green space located in the city of Bari, between Viale Europa and Viale delle Regioni, in the San Paolo district.

The area is currently characterized by a strong degradation state. Crossing the park, portions of broken fences, ruined or damaged public lighting, signs, decayed and vandalized brick wall parts, degraded street furniture and unused walled public toilets are found.

The park requires strong interventions to recover the open space and its elements, as well as to restore public hygiene and safety, in order to make the garden accessible as a place for recreation, aggregation and socialization.

Currently, the park is unused. The neglect state (Fig. 8) does not allow neighborhood inhabitants to enjoy this area as a public garden or a pedestrian crossing. 
An innovative methodological approach for the analysis of the effects of urban interventions on property prices

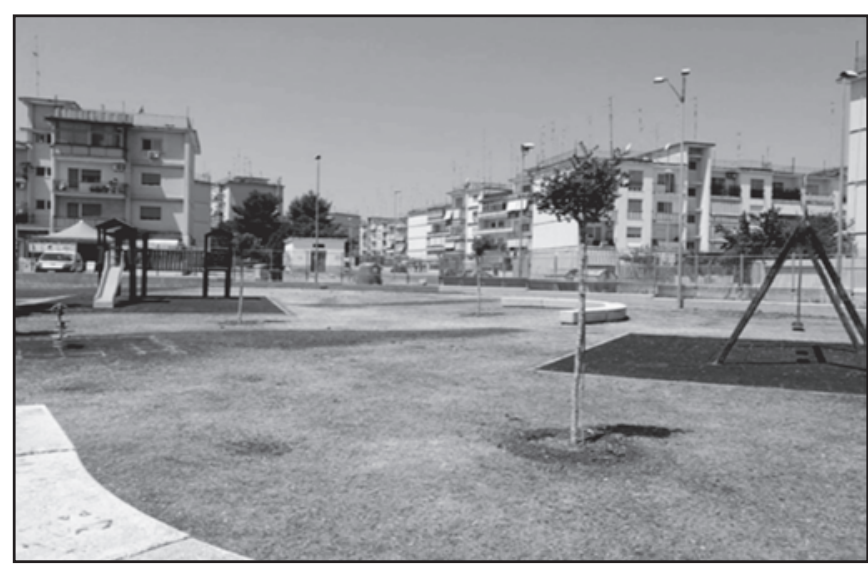

Figure 8 - "Giovanni Paolo II" Park - current state

The redevelopment project

The "Giovanni Paolo II" Park project is part of the wider urban redevelopment program which includes fourteen parks for the city of Bari. The goal of the interventions concerns the provision of facilities and accessories in the neighborhoods to promote the amateur sports, favoring the socialization and aggregation places realization, counteracting social marginalization and isolation. The "Giovanni Paolo II" Park intervention (Fig. 9) aims at the skating rink area recovery, whose degraded conditions negatively influence the urban context aesthetics.

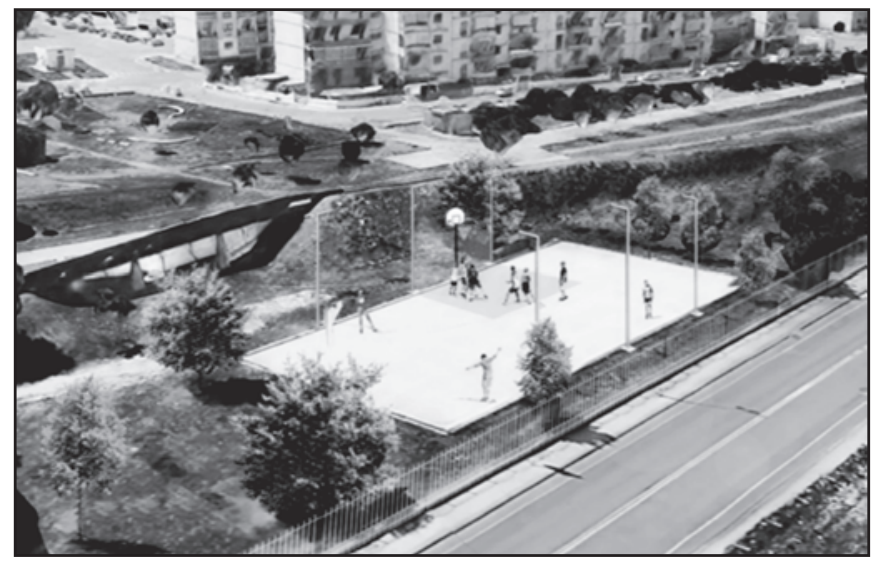

Figure 9 - "Giovanni Paolo II" Park - project situation

\subsection{The collected data}

For each of the four municipal trade areas of the city of Bari, a sample of two hundred residential properties sold in the 2017-2019 period (in particular from the second half of 2017 to the first half of 2019) has been collected. For each property, the selling price and the intrinsic and extrinsic factors that, on the basis of the indications provided by the market operators in the area and of the data generated by the OMI of the Italian Revenue Agency, are taken into account in the negotiation phases by local operators (sellers and buyers) (Bourassa et al., 2003), have been detected.

\subsection{Variables of the model}

With reference to the model to be developed and tested in the present research, the dependent variable is the total selling price $(\mathrm{P})$, expressed in $€$ (euro).

The factors related to perceived urban quality are assessed by submitting the questionnaire proposed for the research, to a sample of two hundred subjects randomly selected for each municipal trade area (eight hundred subjects in total). The questionnaire has been first administered with reference to the "ante-project" situation, in order to assess the urban quality level in the current state and, subsequently, to the "post-project" situation, to evaluate the level quality perceived variation.

The independent variables considered are described below.

\section{Intrinsic variables}

- Total commercial surface of the property, expressed in square meters of gross floor area - S;

- Number of bathrooms in the building - B [n.];

- Floor level on which the property is located - L [n.];

- Presence of the lift in the building where the property is located - A. This variable is considered as a dummy variable (Hardy, 1993): the value "one" indicates the lift presence, whereas the value "zero" represents the absence of the service;

- Presence of the parking space in the building where the property is located - $P$. The variable is assessed as a dummy variable, where the score " 1 " means the presence of the car space, whereas the score " 0 " its lack.

- Quality of the maintenance conditions of the property - Sc. The variable is evaluated as a qualitative variable and it is synthesized by the numerical score: in particular, the score " 1 " is assigned to the properties that require significant refurbishment interventions, the score " 3 " refers to buildings characterized by good maintenance conditions and the score " 5 " indicates properties whose maintenance conditions are excellent.

\section{Extrinsic variable}

With reference to the procedure for the assessment of the urban quality level of the area in which each building of the four study samples is located, the quality components (architectural quality, planning quality, environmental quality, landscape quality, quality of public space, social quality) and the indicators as classified in 
paragraph 3.2 of the present research (objective indicators, "type 1 - subjective indicators" and "type 2 subjective indicators") have been used. For each quality component, the most influential objective and "type 1 subjective indicators" taken into account by buyers and sellers in the negotiations phases in the residential market for the four trade areas of the city of Bari, are reported below. Each perceived urban quality component shown in the questionnaire constitutes an extrinsic variable to be analyzed.

\section{Architectural quality}

Type 1 - subjective indicators:

- Maintenance conditions of the buildings facades adjacent to the property - Sf, assessed through a scores scale assigned by a experts panel, where the score " 1 " indicates a very bad state; the score " 3 " indicates a good state and the score " 5 " an excellent one.

\section{Planning quality}

Objective indicators:

- Distance of the property from the nearest highway (Tangenziale of the city of Bari), calculated in kilometers it takes to get there by car - Dt;

Distance of the property from the nearest railway station calculated in kilometers it takes to walk to it - Ds.

\section{Environmental quality}

Objective indicator:

- Distance of the property from the nearest urban green space, calculated in Kilometers it takes to walk to it - Dv. For the cases considered, the areas selected are the equipped green spaces, squares and public gardens most used by the inhabitants of the city of Bari. In particular, these areas are:

- Gardens of Piazza Umberto I - located in the central municipal trade area.

- Piazza Giuseppe Garibaldi - located in the central municipal trade area.

- Parco 2 giugno - located in the semicentral municipal trade area, close to the central one.

- Punta Perotti Park - located into the central municipal trade area on the border adjacent to the peripheral one.

- Pineta San Francesco - located in the peripheral municipal trade area.

- Pineta Giuseppe Romita - located in the north-western peripheral of the city of Bari in the suburban municipal trade area.
Type 1 - subjective indicators:

- the road private and public vehicular traffic (buses) level of the building area in which each property is located $\mathrm{T}$, assessed through a scale of scores assigned by a team of experts, where the score " 1 " indicates a road characterized by high traffic intensity, the score " 3 " indicates a medium traffic intensity, the score " 5 " refers to roads characterized by low traffic congestion.

\section{Landscape quality}

Objective indicator:

- Distance of the property from the landmark for the local community - architectural and landascape emergence (Araldo di Crollalanza waterfront of the city of Bari ), calculated in Kilometers it takes to walk to it - Dl;

Quality of the public space

Type 1 - subjective indicators:

- Maintenance conditions of the public spaces furniture (public lighting lamps, waste baskets, benches, planters, parking canopies, display boards for billboards, etc.), adjacent to the property - Sa. The variable is assessed in qualitative terms through a scale of scores attributed by panels of experts: the score " 1 " " indicates a bad maintenance conditions of the public spaces, the score " 3 " refers to a good state, the score " 5 " an excellent state.

Social quality

Objective indicator:

- Distance of the property from the nearest food market or grocery shop, calculated in kilometers it takes to walk to it - Dm.

\subsection{The econometric technique}

Starting from the sample data, Evolutionary Polynomial Regression (EPR) is the technique implemented to identify the selling price function starting from the study sample data.

The technique implements a genetic algorithm to combine numerical and symbolic regression methods using polynomial structures (Goldberg, 1989, Giustolisi et al., 2006). Known the dependent variable $(Y)$ and the independent variables $(X i)$, having defined the parameters useful to return the functional form able to determine the relationship $Y=f(X i)$, the generic expression of the non-linear model implemented in EPR is summarized by Eq. (1)

$$
Y=a_{0}+\sum_{i=1}^{n}\left[a_{i} \cdot\left(X_{1}\right)^{(i, 1)} \cdot \ldots \cdot\left(X_{j}\right)^{(i, j)} \cdot f\left(\left(X_{1}\right)^{(i, j+1)} \cdot \ldots \cdot\left(X_{j}\right)^{(i, 2 j)}\right)\right]
$$


An innovative methodological approach for the analysis of the effects of urban interventions on property prices

where $a_{0}$ is the constant additive term, $n$ is the number of additive terms, i.e., the length of the polynomial expression (constant additive term excluded), $a_{i}$ represents the numerical parameter to be assessed for each additive term, $X_{i}$ is the candidate explanatory variables to be selected by the model, $(i, I)$ - with $I=(1, \ldots$, $2 \mathrm{j}$ ) - is the exponent of the $I$-th variable within the $i$-th additive term, $f$ is a function selected by the user from a set of candidate mathematical expression. The exponents $(i, I)$ are also choosen by the user from a range of candidate real numbers.

The central idea of EPR is to search the best function form, i.e. a combination of the independent variables vectors (the chosen variables, model inputs) by performing a regression with the Least Squares Method to obtain the coefficients value of each variable. The phases that define the econometric elaboration process are: $i)$ identification of the model structure; ii) assessment of the parameters. The quantity and complexity of the solutions that the technique generates depend on the maximum terms number and on the exponents that the user defines in the processing preliminary phase.

A recent version of EPR (Giustolisi and Savic, 2009), called EPR-MOGA, applies a multi-objective evolutionary genetic algorithm, as an optimization strategy based on the Pareto frontier. The proposed technique is able to simultaneously pursue different objective functions, such as to define an optimal Pareto frontier of the fixed conflictual objectives, that aim at

i) the maximization of the model accuracy, through the satisfaction of appropriate statistical indicators;

ii) the maximization of the model parsimony, through the minimization of the number of coefficients $\left(a_{j}\right)$ of the equation;

iii) the reduction of the complexity of the model, through the minimization of the number of explanatory variables $(X i)$ of the final equation.

The resulting optimal Pareto front contains the set of the best mathematical models obtained by considering the best compromise between the accuracy of the model (objective $i$ ) and its complexity/parsimony (objective $i i$ and objective iii). At the end of the modeling phase, the optimization strategy allows to obtain a series of equations for the three objectives considered. In this way, a range of solutions is offered to the operator, among which it is possible to select the most appropriate solution according to the specific needs, the knowledge of the phenomenon and the quantity and quality of experimental data used. The main advantage of EPRMOGA technique is the possibility to obtain a set of expressions characterized by a different statistical accuracy and mathematical structure complexity levels. It should be noted that it is not necessary to postulate the "right" form of the model structure before the analysis, since it is the algorithm implemented by the procedure that generates different models. The choice of the best compromise solution between statistical performance and the complexity of the expression is left to the operator, in order to select the most appropriate models according to the specific situation.

With reference to the applications of the EPR-MOGA technique to the real estate market sector, the research in the literature is very few and recent (Morano et al., 2015, Tajani et al., 2015, Morano et al., 2018).

In the present research a further evolution of EPR has been proposed and tested (in addition to the best performances obtainable with the EPR-MOGA Pareto front), that develops generalized prediction models to identify the functional relationships able to simultaneously describe the selling prices mechanism in different study samples (for example, in different territorial contexts). This technique, called Multi-Case Strategy for EPR (MCS-EPR) is used to study a phenomenon in different cases/contexts, in order to represent and interpret it simultaneously (Berardi et al., 2007, Savic et al. 2009). In the situations with different case studies, the MCS-EPR technique allows to define a "generalized" equation for determining the price, able to identify the influential factors between those initially considered and the related functional correlations, valid for all the samples analyzed (territorial contexts). The study samples may concern different urban areas located in the same city or geographical areas located in different cities on the national territory, for which the study of the influence of specific explanatory variables on selling prices is carried out (Morano et al., 2019). Applications of MCS-EPR in the reference literature (Giustolisi et al., 2007; Berardi et al., 2007) have demonstrated the ability of the technique to generate robust models for the representation and interpretation of complex real phenomena.

The mathematical logic of the MCS-EPR technique employs the EPR-MOGA genetic algorithm to identify the polynomial coefficient values for all considered data samples that simultaneously satisfy the three objective functions - maximization of statistical performance, minimization of the number of coefficients and minimization of the number of variables - for all analyzed case studies. Therefore, the MCS-EPR strategy searches for a unique model structure, that is the combination of the explanatory variables able of defining a generalized model valid for all case studies. According to each sample specificity, the genetic algorithm of MCS-EPR returns different coefficients - $a_{0}$ and $a_{i}$ in Eq. (1) - due to the phenomena (e.g. of the market) that characterize the datasets of the different cases analyzed. Thus, the functional correlations (in absolute terms) and the explanatory variables of the equations returned by MCSEPR for the case studies are the same ones, whereas the coefficients $\left(a_{0}\right.$ and $\left.a_{j}\right)$ are different for each sample considered. 
The statistical performance of the analysis carried out by MCS-EPR for each equation is verified using different indicators ( $\mathrm{R}^{2}$ corrected, $\mathrm{AIC}, \mathrm{RMSE}$ ) and tests (ten-fold cross-validation). Furthermore, in order to obtain a model that fits as much as possible to the different samples data set, a generalized Coefficient of Determination $\left(\mathrm{CoD}_{\mathrm{MCS}}\right)$ defined in Eq. (2), is determined:

$$
C o D_{M C S}=1-\frac{\sum_{k=1}^{m} \sum_{N_{k}}\left(y_{k}-y_{\text {detected }}\right)^{2}}{\sum_{N}\left(y_{\text {detected }}-\bar{y}_{\text {detected }}\right)^{2}}
$$

where $m$ is the number of data samples for which a generalized prediction model is required $(k=1, \ldots, m)$; $N_{k}$ is the size (i.e., number of individuals) of the k-th data sample; $N$ is the total number of individuals that constitute all the $m$ data samples in analysis; $y_{k}$ is the value of the dependent variable estimated by the technique through the statistical inference on the $k$-th vector of parameters, $y$ detected is the corresponding observation, and $\bar{y}$ detected is the average value of the collected values in the $m$ data samples.

Similarly as a classic Coefficient of determination, the closer to the unit value the $\mathrm{CoD}_{\mathrm{MCS}}$ is, the more suitable

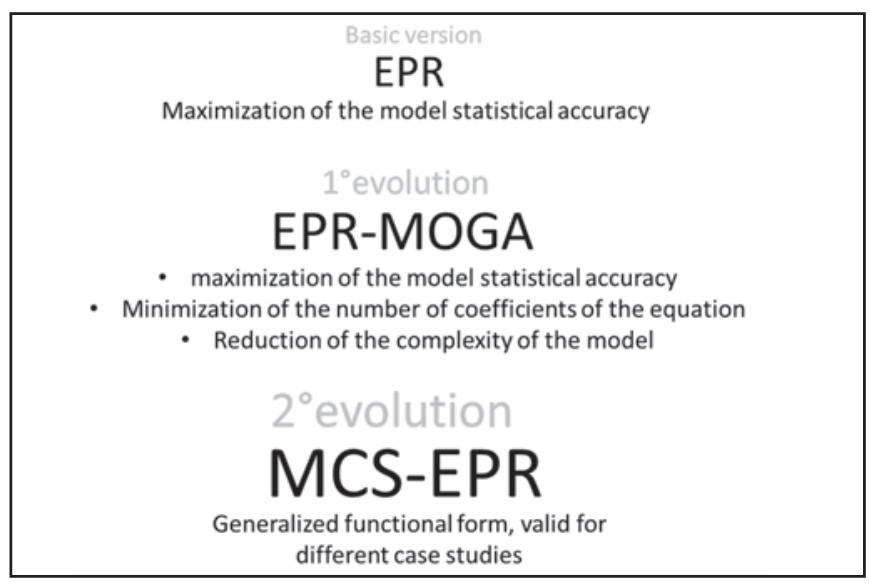

Figure 10 - Evolution of the econometric technique proposed the model structure is in representing the overall observed dataset.

In Figure 10 the evolution of the econometric technique used and of the objectives pursued by the underlying genetic algorithm is summarized.

\subsection{Determination of the generalized model in the "ante-project" situation}

The MCS-EPR technique has been initially implemented on the four case studies in the "ante-project" situation. For all the samples, the dependent variable is constituted by the natural logarithm of the selling price $(Y=\ln (P))$, taking into account the results obtained in several studies (Lynch et al., 2004).

The application of the technique has generated several functions. Among them, the generalized model selected is reported in Eq. (3). It is characterized by a high level of statistical reliability, confirmed both by the classical statistical indicators, and by the $\mathrm{CoD}_{\mathrm{MSC}}$ value equal to $84.18 \%$.

$$
\begin{aligned}
& Y=a_{0}+a_{1} \bullet D s^{0.5} \bullet Q u^{0.5} \bullet Q^{0.5}+a_{2} \bullet S c^{0.5} \bullet D I^{0.5} \\
& \bullet Q a^{0.5} \bullet Q n \bullet Q s+a_{3} \bullet S c+a_{4} \bullet A^{0.5} \bullet D s^{0.5} \bullet \\
& Q p^{0.5}+{ }_{+} a_{5} \bullet L^{0.5} \bullet Q n^{0.5}+a_{6} \bullet B^{0.5} \bullet S a^{0.5} \bullet T^{0.5} \bullet \\
& Q n^{2} \bullet Q s^{2}++a_{7} \bullet S^{0.5}+a_{8} \bullet S
\end{aligned}
$$

The explanatory variables identified by the genetic algorithm implemented in Eq. (3) are the following: distance from the nearest railway station (Ds), perceived planning quality $(\mathrm{Qu})$, perceived environmental quality $(\mathrm{Q} n)$, quality of the maintenance conditions of the property (Sc), distance from the Landmark (DI), perceived architectural quality $(\mathrm{Q} a)$, perceived social quality (Qs), presence of the lift (A), perceived quality of public space $(\mathrm{Qp})$, floor level on which the property is located (L), number of bathrooms in the building (B), maintenance conditions of the public spaces furniture ( $\mathrm{Sa}$ ), road private and public vehicular traffic level where the property is located (T), total surface of the property (S).

With regard to the explanatory variables initially selected as influencing factors on the selling price formation for the four municipal trade areas of the city of Bari, the generalized model of Eq. (3) does not include five

Table 4 - Parameters of the generalized model for each municipal trade area of the city of Bari

\begin{tabular}{|c|c|c|c|c|c|c|c|c|c|}
\hline MUNICIPAL TRADE AREA & $\mathbf{a}_{\mathbf{0}}$ & $\mathbf{a}_{\mathbf{1}}$ & $\mathbf{a}_{\mathbf{2}}$ & $\mathbf{a}_{\mathbf{3}}$ & $\mathbf{a}_{\mathbf{4}}$ & $\mathbf{a}_{\mathbf{5}}$ & $\mathbf{a}_{\mathbf{6}}$ & $\mathbf{a}_{7}$ & $\mathbf{a}_{\mathbf{8}}$ \\
\hline SUBURBAN & +7.09 & +1.53 & -2.73 & 0.82 & 0.41 & 0 & 2.02 & 11.25 & -7.87 \\
\hline PERIPHERAL & +8.32 & +1.69 & 0 & 0.35 & 0.65 & 0 & 5.66 & 6.34 & -2.76 \\
\hline SEMICENTRAL & +9.84 & 0 & 0 & 0.47 & 0.52 & 0 & 0 & 3.33 & 0 \\
\hline CENTRAL & +8.74 & -2.84 & 0 & 0.55 & 1.48 & 0 & 3.06 & 7.61 & -3.69 \\
\hline
\end{tabular}


An innovative methodological approach for the analysis of the effects of urban interventions on property prices

variables: distance of the property from the nearest urban green space (Dv), presence of the parking space in the building where the property is located $(P)$, distance of the property from the nearest food market or grocery shop (Dm), maintenance conditions of the buildings facades adjacent to the property (Sf), distance of the property from the nearest highway (Dt).

Given the generalized functional form, valid for all four case studies, Table 4 shows the values of the coefficients for each municipal trade area analyzed.

In Table 5 the four equations for the municipal trade areas into which the city of Bari is divided, are reported.

It should be observed that the quality of the maintenance conditions of the property $(\mathrm{Sc})$, the presence of the lift (A), the distance from the nearest railway station (Ds), the perceived quality of the public space $(\mathrm{Qp})$ and the total surface of the property $(S)$ are in all four equations with a non-zero multiplicative coefficient. For the other factors of the generalized model, a different market behavior occurs for each of the analyzed samples.

With reference to the variables of perceived urban quality, the equation for the study sample of the suburban municipal trade area includes all the characteristics related to the quality of urban space perceived planning quality $(\mathrm{Qu})$, perceived social quality $(\mathrm{Qs})$, perceived quality of public space $(\mathrm{Qp})$, perceived environmental quality (Qn) and perceived architectural quality $(\mathrm{Q} a)$; in the equations obtained for the study samples of the peripheral and central municipal trade areas, the variables $\mathrm{Qu}$ (perceived planning quality), Qn (perceived environmental quality), Qp (perceived quality of public space) and Qs (perceived social quality) are identified as influential, whereas for Qa (perceived architectural quality) there is no appreciation in the two reference markets; finally, the equation related to the study sample of the semicentral municipal trade area exclusively selects the variable Qp (perceived quality of public space).

For each municipal trade area of the city of Bari, Figures $11,12,13$ and 14 show the functional correlations between the selling prices and the characteristics of urban quality level.

\subsection{Assessment of the urban quality level in the "post-project" situation}

Each of the four interventions considered in the present research generates a variation in the urban quality level into the project area and in the surrounding context. In the functional expressions obtained through the implementation of the MCS-EPR technique on the starting data ("ante-project" situation), this phenomenon translates into variations of the extrinsic factor values selected by the generalized model. The determination of the new values of the factors for which a variation is expected following the implementation of each intervention has carried out through the use of the criteria illustrated (see paragraph 3.2) and also already defined in the present work (objective indicators, type 1 subjective indicators and type 2 - subjective indicators). For the assessment of the perceived quality indicators, the questionnaire has been administered to the same sample of individuals interviewed for the perceived quality measurement in the "ante-project" situation. Following the illustration of each project analyzed for each municipal trade area in the city of Bari, each individual has been asked to formulate a predictive judgment on the perceived quality variation, prefiguring the urban area in the "post-project" situation.

\subsection{Determination of property prices in the "post- project" situation}

The procedure implemented for the assessment of the effects of each urban transformation intervention on property prices is based on the hypothesis that the functional relationships expressed in the generalized model obtained for the "ante-project" situation (Eq. (3)) do not vary after each project realization.

Therefore, it is assumed that the interventions to be carried out in each municipal trade area of the city of Bari do not generate variation in the urban system and that the structural dynamics of the real estate market and, in particular, of the residential sector, are the same of the current state. In this sense, the most influencing factors for the sellers and the buyers do not change compared to those considered in the "ante-project" situation.

Table 5 - Equations related to each municipal trade area of the city of Bari

\begin{tabular}{|c|c|}
\hline MUNICIPAL TRADE AREA & MODEL \\
\hline SUBURBAN & $\begin{array}{l}Y=+1.53 \bullet \mathrm{Ds}^{0.5} \bullet \mathrm{Qu}^{0.5} \bullet \mathrm{Qn}^{0.5}-2.73 \bullet \mathrm{Sc}^{0.5} \bullet \mathrm{Dl}^{0.5} \bullet \mathrm{Qa}^{0.5} \bullet \mathrm{Qn} \bullet \mathrm{Qs}+0.82 \bullet \mathrm{Sc}+0.41 \bullet \mathrm{A}^{0.5} \bullet \\
\bullet \mathrm{Ds}{ }^{0.5} \bullet \mathrm{Qp}^{0.5}+2.02 \bullet B^{0.5} \bullet \mathrm{Sa}^{0.5} \bullet \mathrm{T}^{0.5} \mathrm{Qn}^{2} \bullet \mathrm{Qs}^{2}+11.25 \bullet \mathrm{S}^{0.5}-7.87 \bullet \mathrm{S}+7.09\end{array}$ \\
\hline PERIPHERAL & $\begin{array}{l}Y=+1.69 \bullet D s^{0.5} \bullet \mathrm{Qu}^{0.5} \bullet \mathrm{Qn}^{0.5}+0.35 \bullet \mathrm{Sc}+0.65 \bullet \mathrm{A}^{0.5} \bullet \mathrm{Ds}^{0.5} \bullet \mathrm{Qp}^{0.5}+5.66 \bullet B^{0.5} \bullet \mathrm{Sa}^{0.5} \bullet T^{0.5} \mathrm{Qn}^{2} \bullet \\
\bullet \mathrm{Qs}^{2}++6.34 \bullet \mathrm{S}^{0.5}-2.76 \bullet \mathrm{S}+8.32\end{array}$ \\
\hline SEMICENTRAL & $Y=+0.47 \bullet S c+0.52 \bullet A^{0.5} \bullet D s^{0.5} \bullet Q p^{0.5}+3.33 \bullet S^{0.5}+9.84$ \\
\hline CENTRAL & $\begin{array}{l}Y=-2.84 \bullet D s^{0.5} \bullet \mathrm{Qu}^{0.5} \bullet \mathrm{Qn}^{0.5}+0.55 \bullet \mathrm{Sc}+1.48 \bullet \mathrm{A}^{0.5} \bullet \mathrm{Ds}^{0.5} \bullet \mathrm{Qp}^{0.5}+3.06 \bullet \mathrm{B}^{0.5} \bullet \mathrm{Sa}^{0.5} \bullet T^{0.5} \mathrm{Qn}^{2} \bullet \\
\bullet \mathrm{Qs}^{2}++7.61 \bullet \mathrm{S}^{0.5}-3.69 \bullet \mathrm{S}+8.74\end{array}$ \\
\hline
\end{tabular}




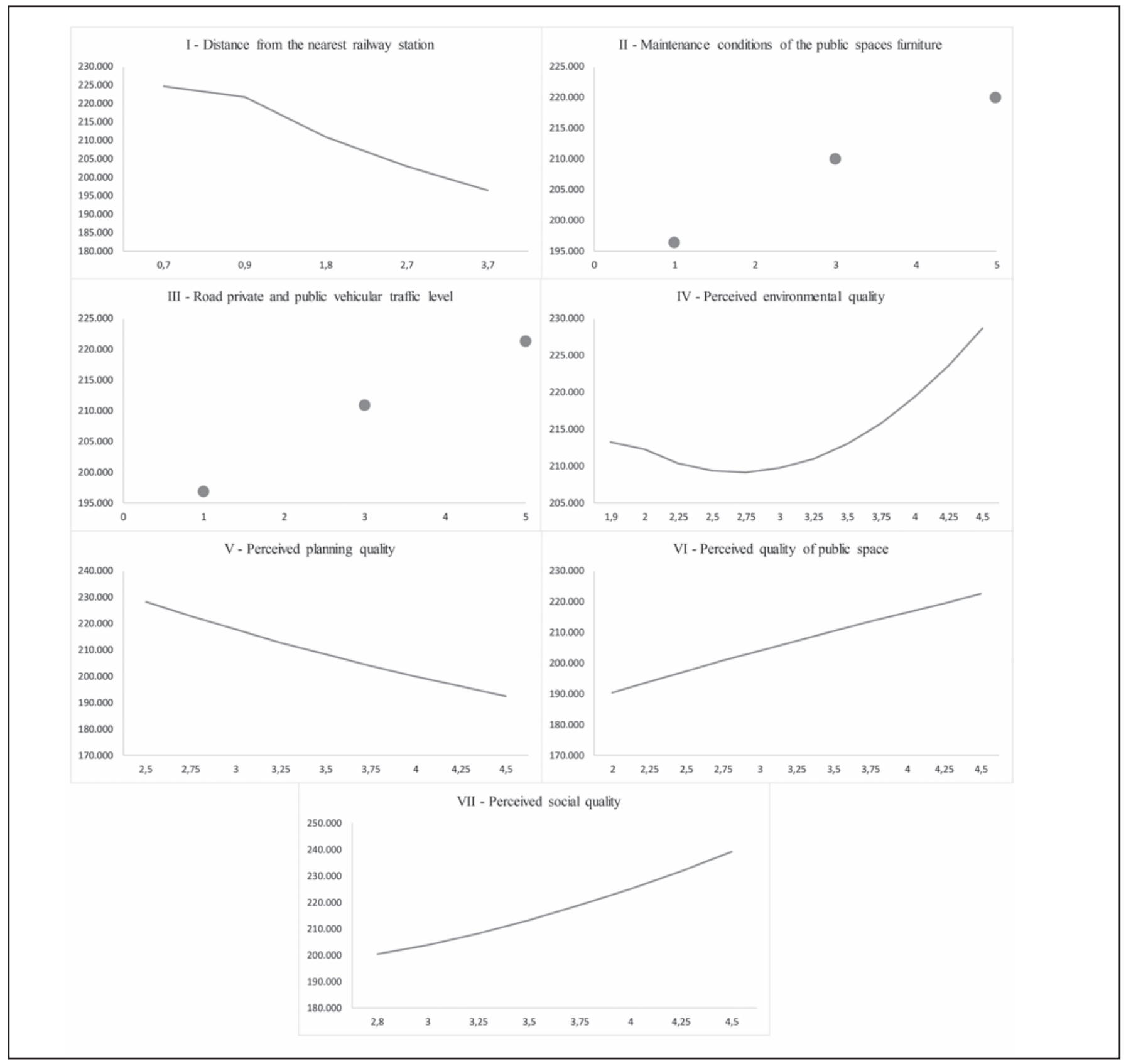

Figure 11 - Functional relationships between property prices and extrinsic variables selected by the generalized model for the central municipal trade area

This is a strong hypothesis.

However, under this hypothesis, it is possible to apply the equations previously obtained (Table 5 ) to determine the property prices in the "post-project" situation, introducing the variations in urban quality factors assessed for the projects realization.

In Table 6 the four mathematical expressions of the price function for the municipal trade areas of the city of Bari are reported, highlighting (in bold) the variables relating to the urban quality for which, following the project, a variation of the values is expected.

\subsection{Comparison of the assessed values in the "ante project" and "post project" situations}

For each municipal trade area of the city of Bari, Figures $15,16,17$ and 18 show the propagation of the effects 
An innovative methodological approach for the analysis of the effects of urban interventions on property prices

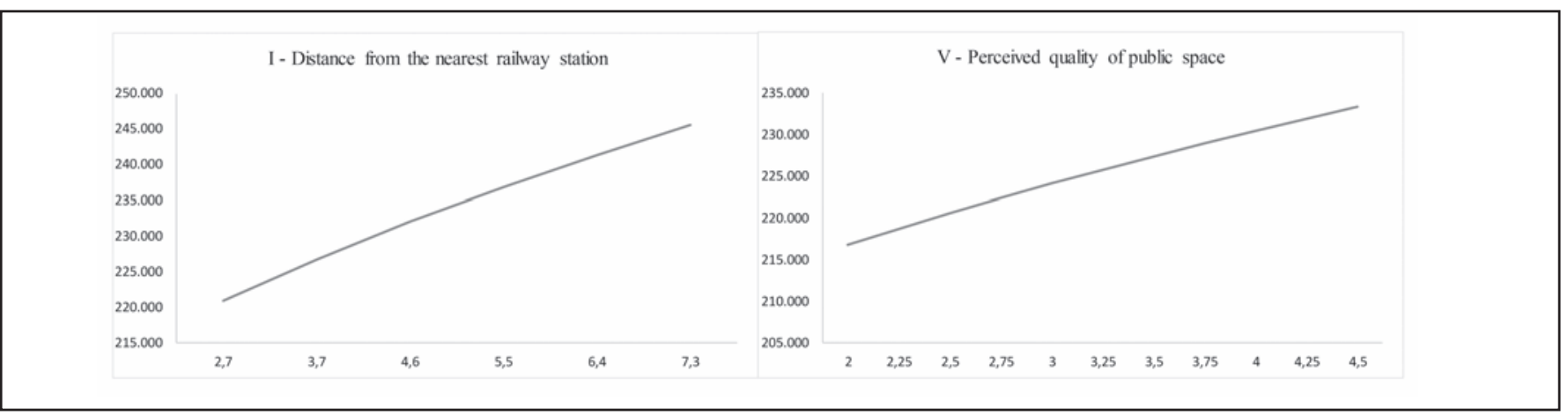

Figure 12 - Functional relationships between property prices and extrinsic variables selected by the generalized model for the semicentral municipal trade area

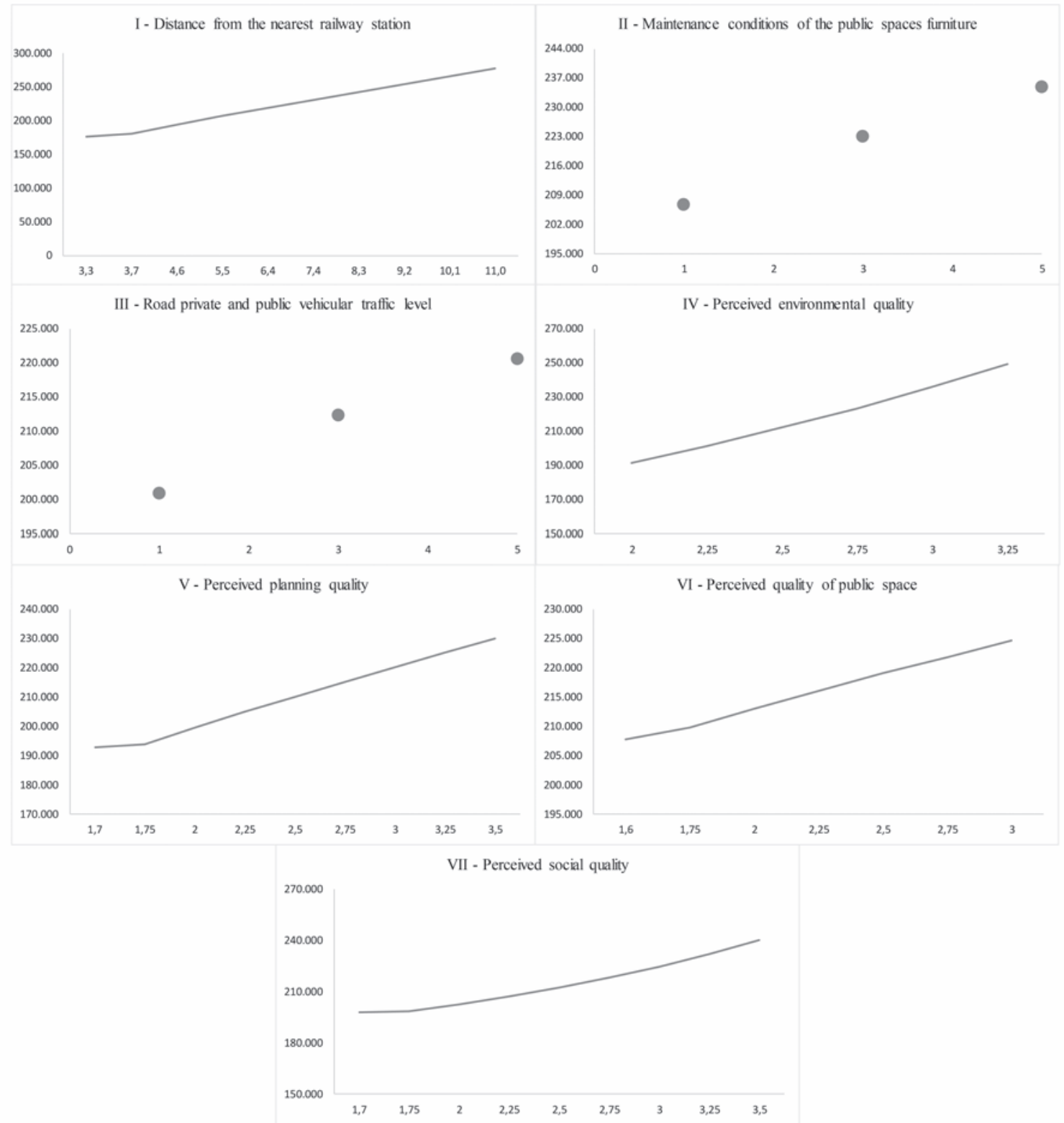

Figure 13 - Functional relationships between property prices and extrinsic variables selected by the generalized model for the peripheral municipal trade area 


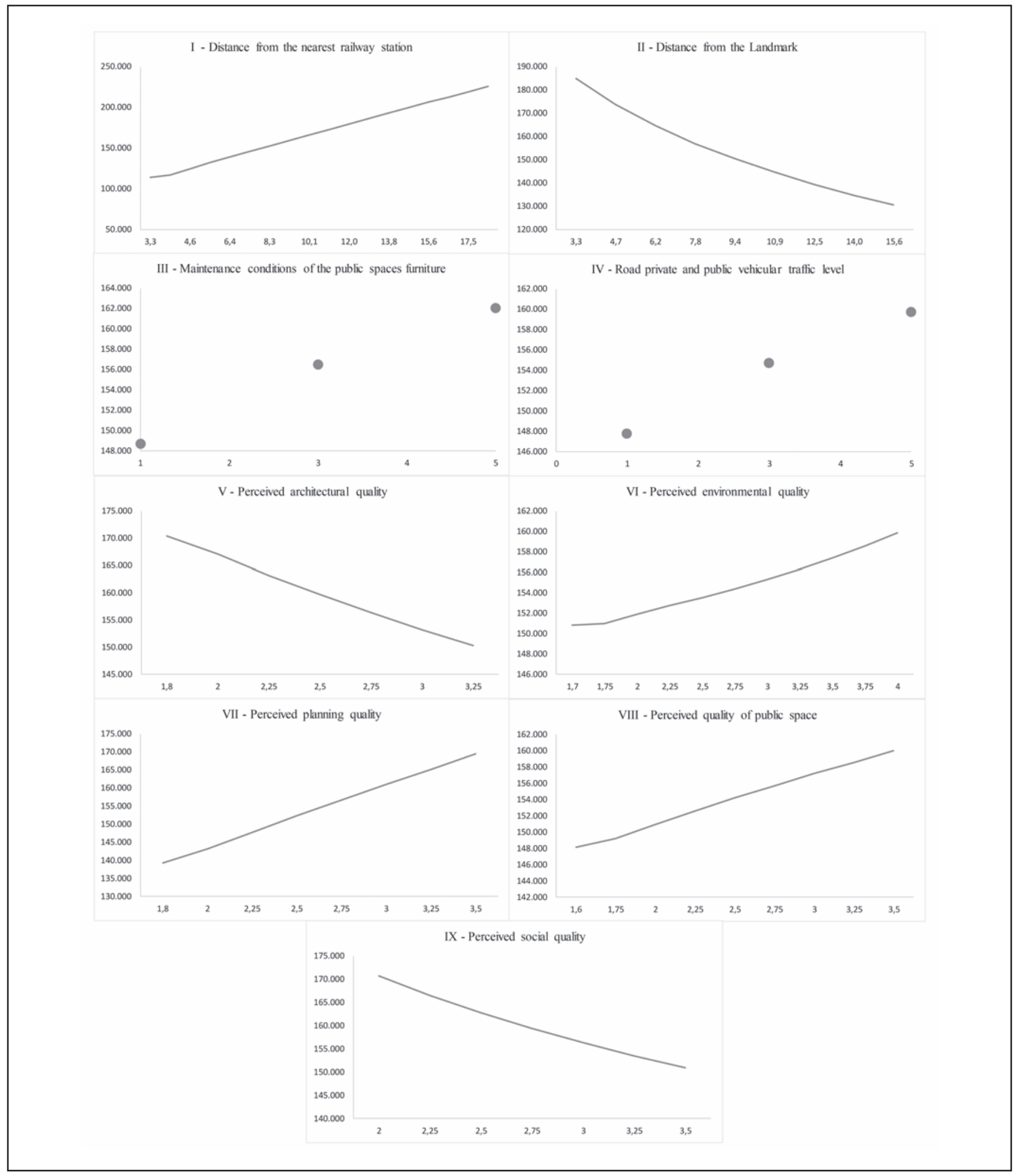

Figure 14 - Functional relationships between property prices and extrinsic variables selected by the generalized model for the suburban municipal trade area 
An innovative methodological approach for the analysis of the effects of urban interventions on property prices

deriving from the implementation of each of the four urban interventions on property prices.

The semicentral, peripheral and suburban trade areas of the city of Bari concern discontinuous urban areas: although spatially separated, these contexts are currently characterized by similar market phenomena according to the dynamics outlined by the Revenue Agency.

The outputs of the analyzes carried out give rise to interesting considerations.

According to the empirical phenomena normally expected, for all the cases, the results obtained show a significant influence on the properties close to the intervention area and a decrease of the market effects on the most distant areas.

The graph in Figure 15 for the central municipal trade area shows a higher variation in property prices for residential units located in the immediate surroundings of the intervention; the propagation effect decreases with the increasing of the distance, and it is equal to the zero value for the properties far from the Murattiano district in which the three project buildings are located. On the other hand, it should be noted that in the historical center of the city, located in the north of the urban center, although close to the intervention, there are no effects in terms of variations in property values: this fact is connected to the specificity of the historic center, characterized by different market and socio-economic factors compared to those of the "Murattiano" district, which neutralize the redevelopment positive effects. The average increase in property values recorded in the central municipal trade area is equal to approximately $+6 \%$ : this contribution confirms the relevance of the construction of the "Polo del Contemporaneo" on the increase of the urban quality perceived level in the central area in architectural, social and public space terms. The result appears consistent with the expected empirical trend, since the project makes it possible to improve the livability conditions of the area. This

Table 6 - Identification of the variables related to urban quality for which, in the "post-project" situation, a variation of the values is expected in the four models obtained for each municipal trade area of the city of Bari

\begin{tabular}{|c|c|}
\hline MUNICIPAL TRADE AREA & MODEL \\
\hline SUBURBAN & $\begin{array}{l}Y=+1.53 \bullet D s^{0.5} \bullet Q u^{0.5} \bullet \mathbf{Q n}^{0.5}-2.73 \bullet S c^{0.5} \bullet D^{0.5} \bullet Q a^{0.5} \bullet \mathbf{Q n} \bullet \mathbf{Q s}+0.82 \bullet S c+0.41 \bullet A^{0.5} \bullet \\
\bullet D s^{0.5} \bullet \mathbf{Q p}{ }^{0.5}+2.02 \bullet B^{0.5} \bullet \mathbf{S a}^{0.5} \bullet T^{0.5} \mathbf{Q n}^{2} \bullet \mathbf{Q} \mathbf{s}^{2}+11.25 \bullet S^{0.5}-7.87 \bullet S+7.09\end{array}$ \\
\hline PERIPHERAL & $\begin{array}{l}Y=+1.69 \bullet D s^{0.5} \bullet Q u^{0.5} \bullet Q n^{0.5}+0.35 \bullet S c+0.65 \bullet A^{0.5} \bullet D s^{0.5} \bullet Q p^{0.5}+5.66 \bullet B \\
\bullet\end{array}$ \\
\hline SEMICENTRAL & $Y=+0.47 \bullet S c+0.52 \bullet A^{0.5} \bullet D s^{0.5} \bullet Q p^{0.5}+3.33 \bullet S^{0.5}+9.84$ \\
\hline CENTRAL & $\begin{array}{l}Y=-2.84 \bullet D s^{0.5} \bullet Q u^{0.5} \bullet Q n^{0.5}+0.55 \bullet S c+1.48 \bullet A^{0.5} \bullet D s^{0.5} \bullet Q p^{0.5}+3.06 \bullet B^{0.5} \bullet S a^{0.5} \bullet T^{0.5} \bullet \\
Q n^{2} \bullet Q s^{2}+7.61 \bullet S^{0.5}-3.69 \bullet S+8.74\end{array}$ \\
\hline
\end{tabular}

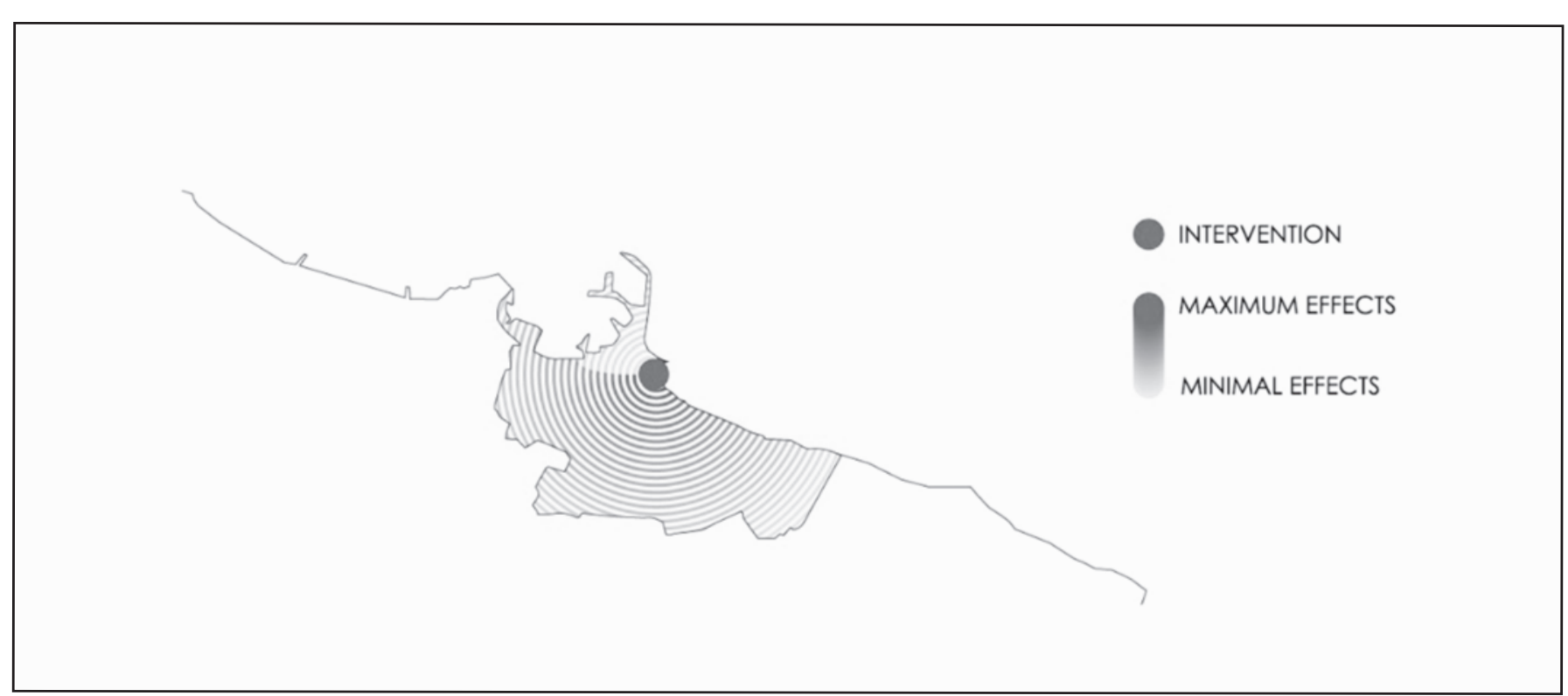

Figure 15 - Graphic representation of the effects on property prices generated by the realization of the "Polo del Contemporaneo" in the central municipal trade area 


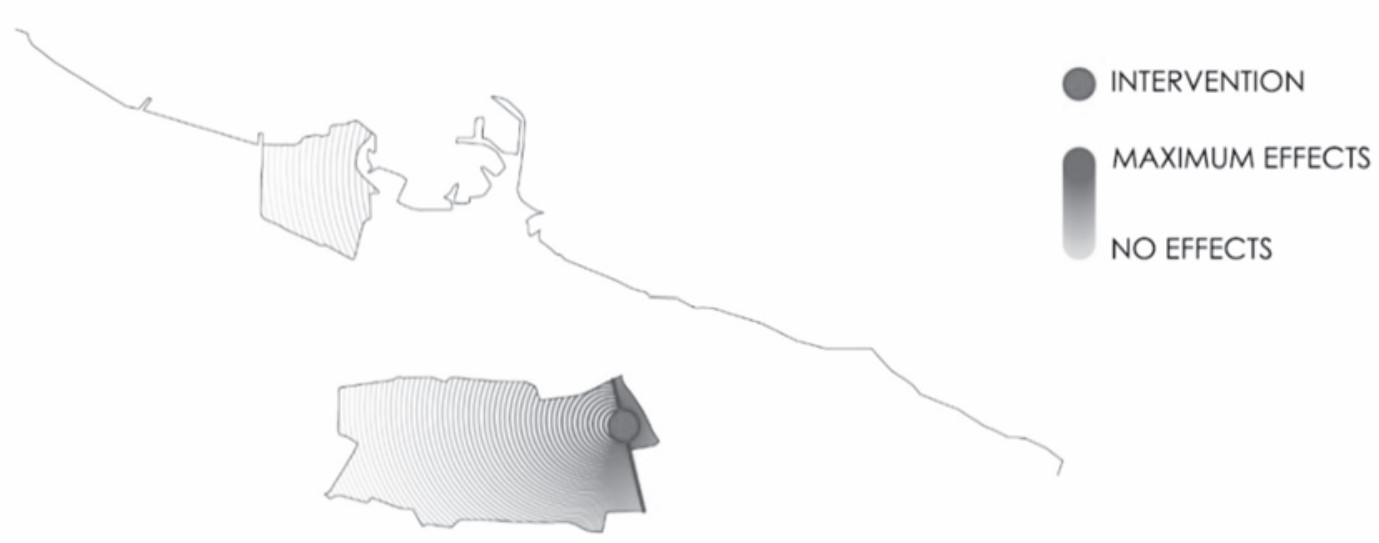

Figure 16 - Graphic representation of the effects on property prices generated by the redevelopment of "via Giovanni Amendola" in the semicentral municipal trade area

phenomenon is perceived by the local real estate market, through the appreciation of historical and architectural buildings able of increasing the cultural offer of the city and promoting a higher touristic flow.

With reference to the semicentral municipal trade area, the graph in Figure 16 highlights the effects of the redevelopment of "via Giovanni Amendola" on the property prices of the residential units next to the project, for which an increase range between $[+3 \%,+5 \%]$ is assessed. Also in this case, the real estate market effects decrease in corrispondence to greater distance from the intervention area. Moreover, the impacts are nil in the area of the semicentral municipal trade area located to the west of the urban center, excessively distant from the intervention.

For the peripheral municipal trade area, the results obtained and represented in Figure 17, show a significant increase in the property values of the residential units near the "San Girolamo" waterfront, thus certifying the positive impacts that the project would determine in

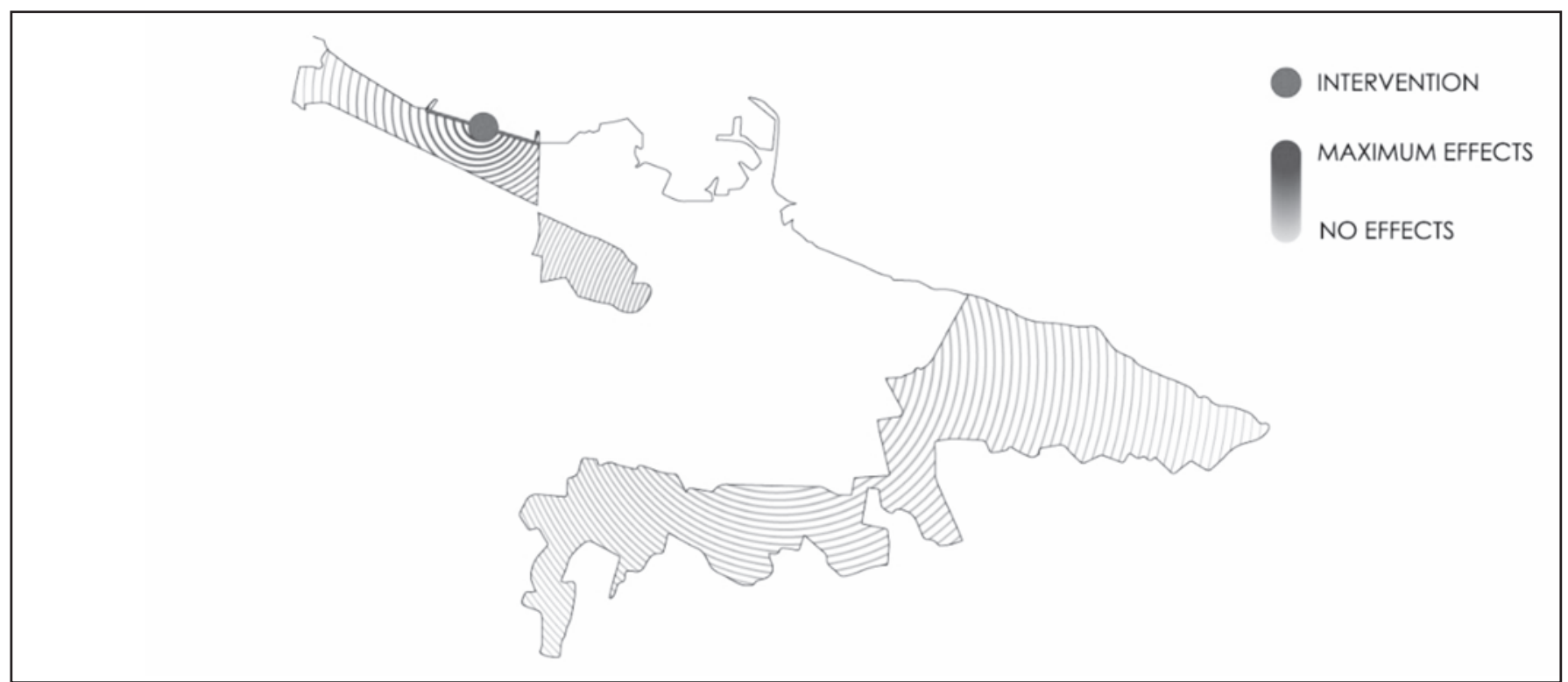

Figure 17 - Graphic representation of the effects on property prices generated by the regenerationt project of the "San Girolamo" waterfront in the peripheral municipal trade area 
An innovative methodological approach for the analysis of the effects of urban interventions on property prices

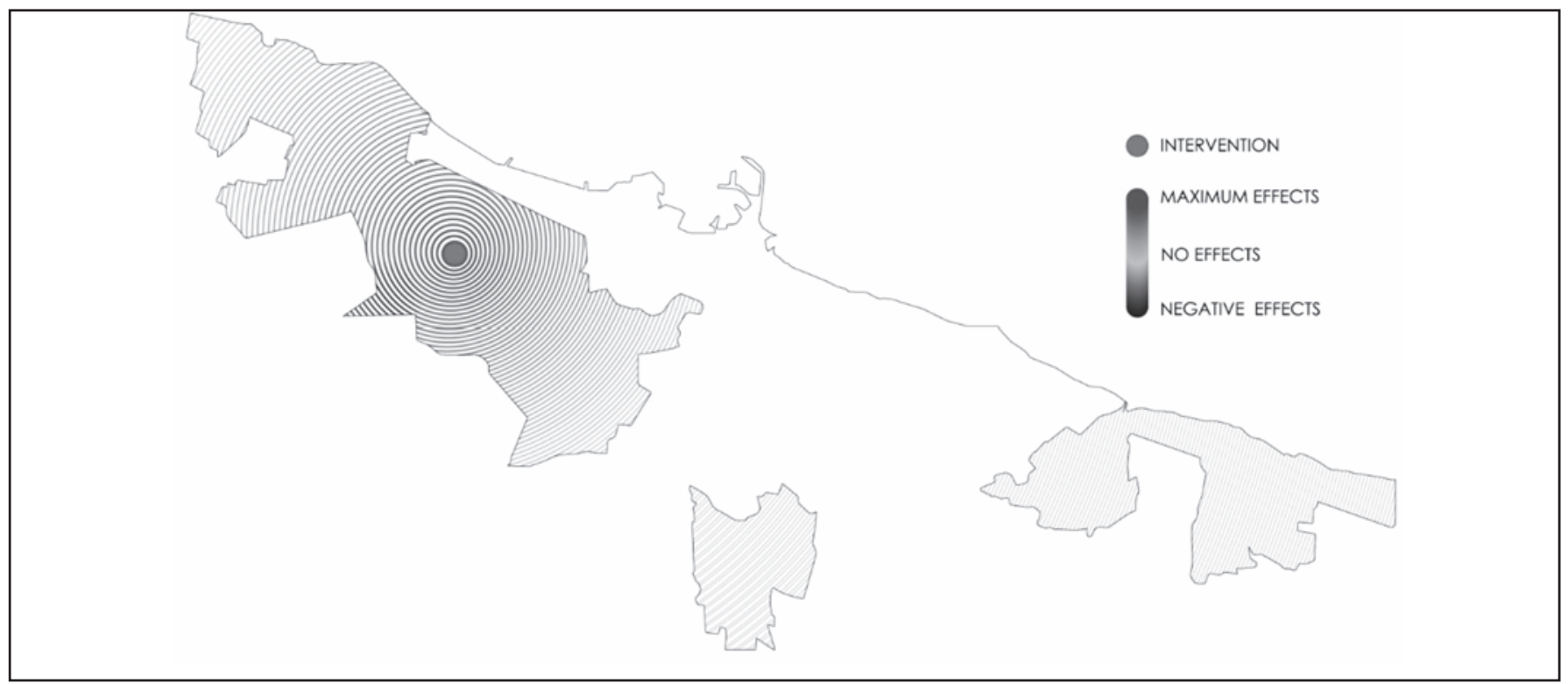

Figure 18 - Graphic representation of the effects on property prices generated by the recovery project of "Giovanni Paolo II" Park in the suburban municipal trade area

terms of improving the urban quality level in the sorrounding context. In fact, the average increase in property prices is equal to about $+32 \%$. It highlights the importance of the redevelopment project for the peripheral area of the city of Bari. The propagation effects are nullified for the properties located in the separate peripheral areas from the urban context in which the intervention is located.

The analysis of Figure 18 for the suburban municipal trade area allows to identify three possible scenarios of property values variation in the "post-project" situation:

i) a significant increase in property prices for the residential units near the "Giovanni Paolo II" Park;

ii) the absence of effects for properties further away from the project and for properties located in the areas of the suburban municipal trade areas disconnected from the area in which the urban park is located;

iii) a decrease in property values for the housing units in the south-west of the project, near the San Paolo hospital and recently built. Therefore, the scenario iii) reflects a possible variation in market demand from the South-West area of the intervention towards houses close to "Giovanni Paolo II" Park. These properties could benefit from the project implementation, in terms of market values, for the realization of an urban amenity that, currently, is represented by a degraded green area.

The average increase in property prices for the suburban municipal trade area is assessed equal to about $+1.4 \%$.

In Table 7 the average percentage variations in property prices in the four municipal trade areas of the city of Bari following the implementation of the urban transformation interventions examined, are shown.
Table 7 - Average increases in property prices following the implementation of each urban intervention and with reference to each municipal trade area

\begin{tabular}{|c|c|c|c|}
\hline \multicolumn{4}{|c}{ MUNICIPAL TRADE AREA } \\
CENTRAL & SEMICENTRAL & PERIPHERAL & SUBURBAN \\
\hline$+6 \%$ & $+0.6 \%$ & $+32 \%$ & $+1.4 \%$
\end{tabular}

\section{CONCLUSIONS}

The goal of the analysis has concerned the definition and testing of an ex ante evaluation protocol of the effects of urban transformation interventions on property prices.

The research has focused on two current and relevant issues: the first is related to urban quality; the second concerns the link between interventions, urban quality and property prices. With reference to these two issues, the research has proposed and tested a new model for assessing urban quality, based on the main strengths of the methodological approaches currently used for its evaluation.

The urban spaces functional reconversion is one of the most important and debated goals in the context of public policies for governing the territory. The redevelopment interventions of degraded or abandoned urban areas allows: to transform underused city portions, located in central and/or strategically relevant positions; to give "quality" on areas that are strongly damaged; to enhance rundown buildings; to provide the city with new places for recreation and social gathering. 
With reference to urban quality analysis, an innovative model has been proposed aimed at assessing the different quality components in quantitative terms. Borrowing the logic of the existing scientific literature tools, the model provides for the quality notion disarticulation in its components and the subsequent evaluation and quantification of them through appropriate indicators.

With regards to the aim of the research, an operational methodological approach has been defined for the analysis of the effects of urban transformation interventions in terms of variations in property prices. The developed approach has led to the procedural protocol definition, divided into phases, able to determine the urban redevelopment effects on the real estate market. This decision support tool for the Public Administration or private investors could be implemented in any territorial context and for any redevelopment initiative. In particular, the protocol can be used in the planning urban redevelopment interventions preliminary phases to $i$ ) verify the effects of different proposed projects in terms of property values and, possibly, recalibrating the design solution to be implemented; ii) compare different design alternatives in order to choose the "best" solution; iii) orient the public and/or for community works planning towards initiatives whose expected regenerative effects are higher; iv) support the negotiations, in the case of initiatives to be implemented in public-private partnership. In the present research, the verification of the effects generated by the redevelopment has been investigated through the study of the variation of property values in the municipal trade areas in the "ante-project" and "post-project" situations.

The protocol has been applied in the city of Bari (Southern Italy). First, four urban interventions in progress have been selected. Each of them is located in one of the four municipal trade areas (central, semicentral, peripheral and suburban) identified by the OMI of the Italian Revenue Agency. For each trade area, a sample of recently sold residential properties has been detected. The implemented econometric procedure has allowed to obtain a generalized price function, valid for the entire municipal area of Bari and able of identifying the best variables set that influences the selling prices formation in the "ante-project" and "post-project" situations. The main advantage of the technique used concerns the ability to generate descriptive models of the property prices formation mechanisms, characterized by a high statistical reliability and at the same time by easily interpretable functional correlations, avoiding the creation of "black boxes" difficult to understand for the possible users. It is evident that the descriptive and predictive potential of the models obtained significantly depends on the size of the study samples: in fact, if the database is not significant, the procedure used may not be able to generate sufficiently reliable outputs.

The developed evaluation protocol will be able to support the traditional financial and economic projects feasibility verification tools currently used, representing a further decision support for public and private operators. With reference to the operations carried out in publicprivate partnerships, the methodological approach will guide the selection of projects that provide for an increase in the urban quality level and a growth in expected property values. This condition allows to identify the initiatives able to have fiscal effects, as generally higher property value corrisponds to higher revenues for public finance.

The proposed procedural protocol is characterized by the flexibility of its phases, allowing the constant monitoring of the different steps and the adaptation to different inputs that may derive from reference context evolutions: the possibility of modeling the actions succession to be carried out to the different territorial areas allows to implement the protocol also to other urban quality aspects, i.e. the health and, more generally, to environmental quality aspects, to the presence of pedestrian road and/or cycle paths. These changes may be proposed by public administrators, by operators in the reference market and by local communities with reference to the characteristics of the urban areas to be redeveloped and to the functional reconversion projects considered.

The work is part of a current and wider research line. The issue of urban redevelopment, as the degraded urban areas regeneration and the existing public and private property assets enhancement, constitutes a constantly evolving issue in the government policies which, linked to the scarce Public Administrations financial resources, requires accurate and adequate selection of the interventions to be implemented.

Future research developments may concern the analysis of synergistic effects of each intervention in a specific municipal trade area on the other urban contexts and, in general, on the entire urban system. In this way, the protocol thus improved will be able to constitute a support to redefine and update the market trade areas perimeters following urban redevelopment interventions. 
An innovative methodological approach for the analysis of the effects of urban interventions on property prices

* Felicia Di Liddo, Department of Science of Civil Engineering and Architecture, Polytechnic University of Bari, Bari email: felicia.diliddo@poliba.it

** Pierluigi Morano, Department of Science of Civil Engineering and Architecture, Polytechnic University of Bari, Bari email: pierluigi.morano@poliba.it

*** Francesco Tajani, Department of Architecture and Design, "Sapienza" University of Rome, Rome email: francesco.tajani@uniroma1.it

**** Carmelo Maria Torre, Department of Science of Civil Engineering and Architecture, Polytechnic University of Bari, Bari email: carmelomaria.torre@poliba.it

\section{Acknowledgments}

The authors would like to thank Dr. Gianni Guerrieri, Central Director of the Real Estate Market Observatory (OMI) and Estimative Services (Italian Revenue Agency), for his availability to provide the necessary data for the analysis carried out and explained in the present research.

\section{Bibliography}

AA.VV., Monitoraggio della rigenerazione urbana attraverso indicatori condivisi, Venezia: AUDIS, 2010.

Adair A., Berry J., Mcgreal S., Deddis B., Hirst S., The financing of urban regeneration, Land Use Policy, Vol.17, No. 2, 2000, pp.147-156.

Agnoletti C., Bocci C., Gli effetti economici e distributivi degli interventi di riqualificazione urbana, Atti del XVII Congresso nazionale Associazione Italiana di Valutazione - AIV -, Napoli, 10-11 Aprile 2014.

Associazione Aree Urbane Dismesse (Audis), Carta Audis della rigenerazione urbana, 2008 (scaricabile dal sito internet: http://www.audis.it/)

Associazione Aree Urbane Dismesse (Audis), Il Protocollo della qualità di Roma Capitale. Definire e valutare la qualità dei progetti urbani complessi, Roma Capitale, Risorse per Roma, 2012.

Beinat E., Nijkamp P. (Eds.), Multicriteria analysis for landuse management, Vol. 9, Springer Science \& Business Media, 1998.

Berardi L., Kapelan Z., "Multi-case EPR strategy for the development of sewer failure performance indicators", in World Environmental and Water Resources Congress 2007: Restoring Our Natural Habitat, Florida (USA), 2007, pp. 1-12.

BoICE R.L., Discounted cash flow analysis and long-term leases, The Appraisal Journal, Vol. 67, No. 2, 1999, pp. 153-156.

Bonaiuto M., Fornara F., Bonnes M., Indexes of perceived residential environment quality and neighbourhood attachment in urban environments: a confirmation study on the city of Rome, Landscape and urban planning, Vol. 65, No. 1-2, 2003, pp. 41-52.

Bottero M., Datola G., Monaco R., Fuzzy Cognitive Maps: un approccio valutativo dinamico per la valutazione dei processi di rigenerazione urbana, Valori e Valutazioni, Vol. 23, pp. 77-90.

Bourassa S., Hoesli M., Peng V.S., Do housing submarkets really matter?, Journal of Housing Economics, Vol. 12, No. 1, 2003, pp. 12-28.

BrzozowsKa K., Cost-benefit analysis in public project appraisal, Engineering economics, Vol. 3, No. 53, 2007, pp. 78-83.

Clark D.E., KAHN J.R., The social benefits of urban cultural amenities, Journal of regional science, Vol. 28, No. 3, 1988, pp. 363-377.

$\mathrm{D}^{\prime} \mathrm{ACCl}$ L., Formazione e simulazione dei valori immobiliari (Tesi di Dottorato, Politecnico di Torino), 2007.

D'ACCI L., "Spatial distribution of social benefit given by urban attractions: A test of UrAD model", in International Conference on Computational Science and Its Applications, Springer, Berlin, Heidelberg, 2009, pp. 237-252.

D'ACCI L., Monetary, subjective and quantitative approaches to assess urban quality of life and pleasantness in cities (hedonic price, willingness-to-pay, positional value, life satisfaction, isobenefit lines), Social Indicators Research, Vol.115, No. 2, 2014, pp. 531-559.

DAS D., Urban quality of life: A case study of Guwahati, Social Indicators Research, Vol. 88, No. 2, 2008, pp. 297-310.

FARINeLli V., Gabrielli L., Ville Venete - L'analisi multicriteri nel processo decisionale per la stima, Recupero e Conservazione, Vol. 133, No. 1, 2016, pp. 1-8.

Figueira J., Greco S., Ehrgott M. (Eds.), Multiple criteria decision analysis: state of the art surveys, Springer Science \& Business Media, Vol. 78, 2005.

Fornara F., Bonaluto M., Bonnes M., Indicatori di qualità urbana residenziale percepita (IQURP). Manuale d'uso di scale psicometriche per scopi di ricerca e applicativi, 
Franco Angeli, Milano, 2010.

Fregonara E., Coscia C., Multi criteria analyses, life cycle approaches and delphi method: A methodological proposal to assess design scenarios | [Analisi multi criteria, approcci life cycle e delphi method: Una proposta metodologica per valutare scenari di progetto], Valori e Valutazioni, Vol. 23, 2019, pp. 107-117.

FrenCH N., Gabrielli L., Discounted cash flow: accounting for uncertainty, Journal of Property Investment \& Finance, Vol. 23, No. 1, 2005, pp. 75-89.

Gabrielli L., Bottarelli M., Financial and economic analysis for ground-coupled heat pumps using shallow ground heat exchangers, Sustainable Cities and Society, Vol. 20, 2016, pp. 71-80.

Giustolisı O., Berard L., Pipe level burst prediction using EPR and MCSEPR. Water Management Challenges in Global Change, 2007, pp. 39-46.

Giustolisı O., SAVIC D., Advances in data-driven analyses and modelling using EPR-MOGA, Journal of Hydroinformatics, Vol. 11, 2009, pp. 225-236

Giustolisı O., SAVIC D., A symbolic data-driven technique based on evolutionary polynomial regression, J Hydroinform, Vol. 8, No. 3, 2006, pp. 207-222.

GoldBerG D.E., Genetic Algorithms in Search, Optimization, and Machine Learning. Addison Wesley. Reading, MA, 1989.

Guarini M.R., D’addabbo N., Morano P., Tajani F., Multicriteria analysis in compound decision processes: the AHP and the architectural competition for the chamber of deputies in Rome (Italy), Buildings, Vol. 7, No. 2, 2017, p. 38.

Guarini M.R., Battisti F., Chiovitti A., Public initiatives of settlement transformation: A theoretical-methodological approach to selecting tools of multi-criteria decision analysis, Buildings, Vol. 8, No. 1, 2018, p. 1.

HALL P., "Towards a general urban theory", in Brotchie G.F., Batty M., Blakley E., Hall P. (Eds.), Cities in Competition: Productive and sustainable cities for the 21st century, Longman, Melbourne, pp. 3-31.

Hardy M.A., Regression with Dummy Variables, Sage Publications, No. 93, 1993.

Helfert ERIC A., Financial analysis tools and techniques: a guide for managers, McGraw-Hill, New York, 2001, pp. 221-296.

HERBOHN J.L., HARRISON S.R., "Introduction to discounted cash flow analysis and financial functions in EXCEL", in Harrison S. R., Herbohn J. L., Mangaoang E., Vanclay J, Socio-Economic Research Methods in Forestry: A Training Manual, Rainforest CRC, Cairns, 2002, pp. 109118.

KISHORE R., Discounted cash flow analysis in property investment valuations, Journal of Property Valuation and Investment, Vol. 14, No. 3, 1996, pp. 63-70.

Kort M., KuIJN E.H., Public-private partnerships in urban regeneration projects: organizational form or managerial capacity?, Public Administration Review, Vol. 71, No. 4, 2011, pp. 618-626.

LAMBIRI D., BIAGI B., ROYUELA V., Quality of life in the economic and urban economic literature, Social Indicators Research, Vol. 84, No. 1, 2007, p. 1.

LAYARD P.R.G., Cost-benefit analysis, Cambridge University Press, 1994.

LICHFIELD N., Cost-Benefit Analysis in urban redevelopment, 1962.

lora E., Powell A., Van Praag B.M., Sanguinetti P. (Eds.), The quality of life in Latin American cities: Markets and perception, The World Bank, 2010.

LuDLOW D., Ensuring quality of life in Europe's cities and towns. Tackling the environmental challenges driven by European and global change. European Environment Agency, Report No 5/2009, 2009.

LYNCH A.K., RAsmussen D.W., Proximity, neighbourhood and the efficacy of exclusion, Urban Studies, Vol. 41, No. 2, 2004, pp. 285-298.

MARGLIN S.A., Approaches to dynamic investment planning, Amsterdam, North-Holland, 1963.

Morano P., Rosato P., Tajani F., Manganelli B., Di Liddo F., Contextualized Property Market Models vs. Generalized Mass Appraisals: An Innovative Approach, Sustainability. Vol. 11, No. 18, 2019, p. 4896.

Morano P., TAJANi F., Locurcio M., Land use, economic welfare and property values: an analysis of the interdependencies of the real-estate market with zonal and socio-economic variables in the municipalities of Apulia region (Italy), International Journal of Agricultural and Environmental Information Systems (IJAEIS), Vol. 6, No. 4, 2015, pp. 16-39.

Morano P., TAJANi F., LoCurCiO M., Multicriteria analysis and genetic algorithms for mass appraisals in the Italian property market, International Journal of Housing Markets and Analysis, Vol. 11, No. 2, 2018, pp. 229-262.

Morano P., Tajani F., Guarini M.R., Di LidDo F., Iniziative di riqualificazione urbana in partenariato pubblicoprivato: un modello per la definizione di liste di priorità temporale, Laborest, No. 20, 2020.

MuNDA G., Social multi-criteria evaluation for a sustainable economy, Vol. 17, Berlin, Springer, 2008.

Nijkamp P., Rietveld P., VoOgd H., Multicriteria evaluation in physical planning, Vol. 185, Elsevier, 2013.

Richards R., O'LEARY B., MutsonziWA K., Measuring quality of life in informal settlements in South Africa, Social indicators research, Vol. 81, No. 2, 2007, pp. 375-388.

ROGERSON R.J., Quality of life and city competitiveness, Urban Studies, Vol. 36, No. 5-6, 1999, pp. 969-985.

Rosato P., Un modello di analisi multicriteri per la localizzazione di infrastrutture lineari in aree ad insediamento diffuso, Aestimum, No. 36, 1999.

Rosato P., Breil M., Giupponi C., \& Berto R., Assessing the 
An innovative methodological approach for the analysis of the effects of urban interventions on property prices

impact of urban improvement on housing values: a hedonic pricing and multi-attribute analysis model for the historic Centre of Venice, Buildings, Vol. 7, No. 4, 2017, 112.

Sassone P.G., Schaffer W.A., Cost-benefit analysis: A handbook, New York: Academic Press, Vol. 182, 1978.

Savic D.A., Giustolisı O., Laucellı D., Asset deterioration analysis using multiutility data and multi-objective data mining, Journal of Hydroinformatics, Vol. 11, No. 3-4, 2009, pp. 211-224.

ShIN D.C., RutKowski C.P., PARK C.M., The quality of life in Korea: Comparative and dynamic perspectives, Social Indicators Research, Vol. 62,63, 2003, pp. 3-36.

Tajani F., Morano P., Locurcio M., D'addabbo N., "Property valuations in times of crisis: artificial neural net-works and evolutionary algorithms in comparison", in International Conference on Computational Science and Its Applications, Springer, Cham, 2015, June, pp. 194-209.

\section{Internet references}

GeOPOI_Omı - Agenzia del Territorio, Agenzia delle Entrate, http://www.agenziaentrate.gov.it/ 


\title{
Un approceio
}

metodologico innovativo per l'analisi degli effetti degli interventi di trasformazione urbana sui valori immobiliari

Felicia Di Liddo*, Pierluigi Morano**, Francesco Tajani***,

Carmelo Maria Torre ${ }^{* * * *}$ parole chiave: riqualificazione urbana, valorizzazione immobiliare, qualità urbana, valore di mercato, mercato residenziale

\begin{abstract}
La valutazione degli effetti che un intervento di trasformazione urbana induce sullo spazio in cui interviene, e più in generale sul sistema-città, riveste un ruolo centrale nella definizione dell'efficacia dell'intervento, in quanto misura le ricadute che possono derivare dalla sua realizzazione in termini di miglioramento del livello di qualità dell'ambiente naturale e costruito. La presente ricerca intende proporre e testare un approccio metodologico e operativo con il quale si renda possibile valutare, con indicatori quantitativi, gli effetti che un'iniziativa di riqualificazione urbana può determinare sui valori immobiliari. In particolare, l'obiettivo del lavoro concerne la messa a punto di un protocollo procedurale articolato in fasi chiare e ripercorribili a supporto dell'analisi degli effetti di trasformazione urbana. II protocollo è applicato a quattro interventi di riqualificazione in corso di realizzazione in altrettanti ambiti nella città di Bari (Sud Italia). Per ciascun ambito urbano è stato raccolto un campione di circa duecento immobili residenziali compravenduti nel periodo 2017-2019, di

prezzo e caratteri noti. L'implementazione su questi dati di un algoritmo genetico ha permesso di costruire la funzione econometrica del prezzo, in grado di identificare il set di variabili - intrinseche ed estrinseche - che in ciascuno dei quattro ambiti di intervento concorrono alla formazione dei valori immobiliari nella situazione "ante intervento". È stata poi condotta l'analisi degli effetti della riqualificazione urbana in termini di variazione della qualità urbana indotta. Con un approccio esogeno basato sull'intervista di soggetti esperti e di cittadini, sono stati rideterminati $i$ valori delle variabili afferenti alla qualità urbana a valle dell'attuazione dei progetti (situazione "post intervento"). Inserendo questi nuovi valori nelle funzioni econometriche del prezzo già trovate, sono stati stimati i valori di mercato della situazione ex post. I/ confronto tra i valori di mercato ex ante ed ex post rivela l'aumento dei valori immobiliari a valle della riqualificazione e permette di quantificarlo, confermando la piena coerenza con gli andamenti empirici attesi.
\end{abstract}




\section{INTRODUZIONE}

Le politiche di riqualificazione dello spazio urbano sono tra le questioni di maggior rilievo nell'ambito del dibattito sulla ripresa dalla crisi economica innescata nel 2007 dai subprime americani e tuttora in corso.

In tal senso le aree degradate o dismesse, considerate fino ad oggi dei vuoti urbani e luoghi di concentrazione del disagio sociale, iniziano a essere viste come una opportunità per lo sviluppo economico delle città, in quanto possibili contenitori di funzioni conformi ai bisogni e alle istanze della collettività.

I processi di riqualificazione di porzioni più o meno estese del territorio o di singoli edifici, agiscono sul sistema degli insediamenti e producono effetti sull'intera città, determinando esternalità di carattere economico e sociale che si riflettono sulla sua immagine (Agnoletti et al., 2014). La quantificazione di tali impatti ha un ruolo importante per orientare i processi decisionali degli investitori pubblici e privati.

Negli ultimi anni, si è manifestata, con intensità crescente, l'esigenza di stimare e di misurare - in termini sociali, economici ed ambientali - gli effetti generati dagli interventi di trasformazione del territorio (Rosato, 2017).

Il concetto di "qualità urbana", inteso quale obiettivo da perseguire nell'ambito dei processi insediativi e delle dinamiche territoriali, è attualmente oggetto di accesi dibattiti tra urbanisti, architetti, economisti, ambientalisti, antropologi e sociologi. La "qualità" di un luogo si lega imprescindibilmente alla qualità della vita della collettività, in quanto influenza il benessere dei cittadini che vi risiedono o che lo frequentano, in termini di salute e di tranquillità psicologica. La relazione che si instaura tra il livello della qualità dell'ambiente urbano ed il benessere sociale, fisico, mentale ed economico di coloro che lo abitano (Ludlow, 2009; Morano et al., 2020) dimostra l'importanza della valorizzazione degli spazi pubblici, spesso caratterizzati da condizioni di degrado o in stato di abbandono, attraverso azioni strategiche miranti al raggiungimento di un elevato standard qualitativo.

Il tema della dismissione e della riconversione funzionale delle aree degradate e del patrimonio immobiliare dismesso è ampiamente affrontato nella letteratura estimativa e nella pratica urbanistica (Adair et al., 2000; Kort et al., 2011; Bottero et al., 2019). A tali beni è riconosciuto un ruolo fondamentale per:

i) ridefinire l'assetto di un più ampio sistema territoriale,

ii) innalzare la qualità dell'ambiente costruito,

iii) accrescere la competitività della città,

iv) stimolare gli investimenti,

v) migliorare ed arricchire l'offerta urbana.

Nella pratica, la selezione dei progetti destinati a comporre un programma di investimento, quando non è guidata da ragioni di carattere politico o da urgenze connesse alla scadenza di finanziamenti, è affidata a strumenti di valutazione che consentono di verificare la fattibilità dell'in- tervento in ragione del punto di vista di tutti i soggetti coinvolti nell'iniziativa, contemperando al meglio le convenienze delle parti interessate. Le analisi finanziarie (es. Analisi Costi-Ricavi), svolte esclusivamente dal punto di vista del soggetto privato (promotore dell'operazione), riguardano la verifica della convenienza del progetto "in sé", ossia la sua capacità di rimborsare il capitale di debito e di generare un profitto per l'investitore (Kishore, 1996; Helfert et al., 2001; Herbohn et al., 2002; French et al., 2005). Le analisi di tipo economico (es. Analisi Costi-Benefici) allargano il punto di vista della valutazione alla collettività, e mettono a confronto gli effetti generati dalla realizzazione dell'intervento in termini di ricadute positive e negative (Lichfield, 1962; Marglin, 1963; Sassone et al., 1978; Layard, 1994; Boice, 1999; Brzozowska, 2007; Gabrielli et al., 2016). Attesa la frequente difficoltà di tradurre in termini monetari gli effetti economici di un intervento sul territorio, si riscontra un crescente interesse verso le tecniche multicriteri, che consentono di tener conto della natura multidimensionale delle valutazioni di piani e progetti urbani e di perseguire contemporaneamente più obiettivi, mediante la definizione di una soluzione di compromesso tra le differenti istanze di natura economica, sociale ed ambientale (Rosato, 1998; Beinat et al., 1998; Figueira et al, 2005; Munda, 2008; Nijkamp et al., 2013; Farinelli et al., 2016; Guarini et al., 2017; Guarini et al., 2018; Fregonara et al., 2019).

\section{SCOPO DEL LAVORO}

La presente ricerca è da inquadrare nel contesto delineato, e punta all'analisi sistematica degli effetti degli interventi di trasformazione urbana sui valori immobiliari.

L'obiettivo del lavoro è di mettere a punto un approccio metodologico con il quale sia possibile valutare, in fase ex ante ed in termini quantitativi, gli effetti che un intervento di trasformazione urbana può generare sui valori immobiliari. Lo studio, in particolare, si concentra su due tematiche

- la prima riguarda la nozione di "qualità urbana";

- la seconda è relativa al legame esistente tra gli interventi sul territorio, la qualità urbana e i valori immobiliari.

Nello specifico, la ricerca punta alla definizione e alla sperimentazione

i) di un modello innovativo di valutazione della qualità urbana

ii) di un approccio metodologico-operativo che consenta la valutazione degli effetti generati dagli interventi di trasformazione urbana sui valori immobiliari.

L'approccio metodologico-operativo di seguito sviluppato, vuole essere uno strumento originale a supporto dei processi decisionali di pianificazione urbana, di riqualificazione di asset immobiliari e/o di rifunzionalizzazione di spazi collettivi. L'approccio in questione dovrà consentire la valutazione delle ricadute di un intervento sulla qualità urbana e sui valori immobiliari e, in presenza di differenti 
alternative progettuali, la definizione di una lista di priorità temporale sulla base degli impatti che ciascuna ipotesi progettuale genera sul contesto di riferimento. Questo strumento, da codificare in un apposito protocollo procedurale strutturato in fasi dai contenuti chiari e ripercorribili, potrà essere impiegato dalle Pubbliche Amministrazioni e/o, in caso di partenariato pubblico-privato, dagli investitori privati, con l'obiettivo di identificare le porzioni urbane sulle quali c'è la maggiore convenienza ad intervenire in ragione degli effetti positivi attivabili sui valori immobiliari.

Il lavoro è organizzato come segue. Nella sezione 3 è indagata la nozione di "qualità urbana": dopo un breve inquadramento degli aspetti salienti che caratterizzano tale concetto, è illustrato il modello che si propone per la valutazione della qualità dello spazio urbano. Nella sezione 4 è delineato un protocollo procedurale articolato in fasi, da implementare per la valutazione degli effetti degli interventi di trasformazione urbana sui valori immobiliari. Nella sezione 5 il protocollo è applicato ad un caso di studio relativo alla città di Bari: sono specificati gli interventi di trasformazione urbana in corso sulla città presi in considerazione e sono definite le variabili del modello; è illustrata la tecnica econometrica impiegata per la definizione della funzione del prezzo degli immobili; la tecnica è implementata; sono esposti i risultati ottenuti nella situazione "ante intervento"; è poi sviluppata I'analisi degli effetti nella situazione "post intervento" mediante

i) la quantificazione della variazione del livello di qualità urbana conseguente all'attuazione dei progetti,

ii) la determinazione dei nuovi valori immobiliari,

iii) il confronto dei valori stimati nelle situazioni "ante intervento" e "post intervento";

sono, in ultimo, sintetizzati i risultati ottenuti in termini di effetti delle iniziative in questione sui valori immobiliari.

Nella sezione 6, infine, sono discusse le conclusioni del lavoro e le prospettive future della ricerca.

\section{LA QUALITÀ DELLO SPAZIO URBANO}

II rapporto tra uomo, ambiente naturale ed ambiente antropizzato è, per sua natura, complesso. Nell'ambito delle scienze sociali, numerosi studi affrontano la questione del benessere individuale e collettivo, non soltanto in termini di ricchezza economica, ma anche di livello di qualità della vita. Al riguardo, il crescente interesse nell'economia urbana per questa tematica deriva dall'influenza che la qualità della vita esercita sulla crescita e sulla competitività delle città.

Il concetto di qualità urbana racchiude in sé una articolata caratterizzazione che coglie e rispecchia la natura di un sistema complesso quale è la città.

La qualità è un valore relativo graduale, varia in funzione degli utenti, dei luoghi e delle loro diverse e specifiche utilizzazioni, ma soprattutto cambia con i tempi e con la cultura, con i costumi e con i gusti. Non costituisce una proprietà di cui è possibile verificare la presenza, in quanto non si manifesta in termini assoluti e tangibili. II giudizio sulla qualità di un luogo è espresso dagli stessi fruitori di tale spazio ed è connesso ad aspetti culturali, sociali ed economici della popolazione di riferimento, alla loro storia e identità. Non esiste un canone univoco e generalmente valido in grado di misurare la qualità urbana, in quanto la valutazione della qualità di un luogo, così come il benessere o la qualità della vita, sono fortemente legati alle percezioni individuali, interiori e soggettive.

La qualità degli ambienti urbani non deriva unicamente dal rispetto delle previsioni contenute negli strumenti urbanistici, soprattutto se questi non sono sorretti a monte da una progettazione in grado di garantire l'integrazione di tutte le esigenze della popolazione. Né discende dal mero rispetto degli standard urbanistici, in quanto non è sufficiente modificare i rapporti quantitativi fra le destinazioni per ottenere automaticamente la certezza della loro fruizione da parte di tutti i cittadini. Per di più, la presenza di servizi in un sistema territoriale non basta ad assicurare un livello elevato di qualità urbana, perché è necessario che siano anche garantiti i corretti rapporti di proporzionalità, I'equa distribuzione e I'accessibilità dei servizi. Allo stesso modo, risulterebbe riduttivo identificare la qualità urbana solo con la "buona architettura" degli edifici, perché quest'ultima perde valore se non è riferita ad un rapporto con il suo uso e con il contesto in cui si inserisce.

Il tema della qualità urbana ha ormai assunto una rilevanza particolare nell'ambito della progettazione degli interventi sul territorio, costituendo un obiettivo primario a cui tendere nel governo del territorio che mira allo sviluppo sociale e alla crescita economica delle città.

\subsection{Gli indicatori della qualità urbana}

Negli ultimi anni, differenti ricerche hanno tentato di esplicitare la natura multidimensionale della qualità urbana, e altresì di quantificarla ai fini della ricerca empirica. Questi studi si fondano sul presupposto euristico secondo cui l'ambiente sociale e fisico di un'area influisce sul benessere dei fruitori, generando un senso di soddisfazione (o di insoddisfazione) di tale spazio. Tale tematica è ampiamente affrontata nell'ambito delle discipline psicologiche. Gli economisti, d'altra parte, si concentrano principalmente sul rapporto fisio-psicologico, al fine di indagare l'influenza di tale elemento sulla percezione delle caratteristiche delle differenti zone urbane e sul comportamento di ciascun individuo nelle stesse (Lambiri et al., 2007). Rogerson (1999), ad esempio, analizza il legame esistente tra la qualità della vita e le scelte di insediamento di imprese e di individui, evidenziando come il livello di qualità della vita possa essere usato per la promozione di una location al fine di attrarre potenziali investitori. Allo stesso modo, Hall (1995) identifica i fattori della qualità che potrebbero contribuire al miglioramento dello sviluppo urbano. In Shin et al. 2003 le due dimensioni - oggettiva e soggettiva - della qualità della vita sono assunte come identità distinte. La prima fa riferimento a compor- 
tamenti manifesti e a condizioni di fatto su fattori osservabili, quali la ricchezza economica di una città, la salute dei suoi cittadini, ecc., misurati sulla base della frequenza con la quale il fenomeno si manifesta nei luoghi, spesso aggregati e raggruppati in indici sintetici per attuare confronti a livello nazionale e internazionale: si pensi alla ricchezza economica di un Paese misurata in termini di PIL, alla longevità media della popolazione, al grado di istruzione, al livello medio di analfabetismo, alla disoccupazione, ecc. (D'Acci, 2007, 2009).

Gli indicatori oggettivi potrebbero, tuttavia, non riflettere accuratamente la percezione di benessere da parte dei fruitori dei luoghi, dal momento che il benessere è un'emozione complessa da definire e, di conseguenza, da quantificare (Das, 2008).

La seconda componente della qualità della vita - quella soggettiva - attiene alla sfera psicologica dei fruitori ed al grado di soddisfazione esternato dagli stessi. Tale componente mira alla valutazione individuale delle condizioni della qualità della vita, in termini di benessere percepito e vivibilità del luogo in cui si sta e si lavora, mediante l'impiego di indicatori che riflettono gli stati d'animo e le percezioni relative al grado di realizzazione lavorativa, all'appagamento delle ambizioni, al grado di tranquillità psicologica, alla soddisfazione dei bisogni primari, alla gratificazione a livello individuale e collettivo.

Pur instaurando una stretta relazione, le due dimensioni del benessere - oggettiva e soggettiva - non sono correlate direttamente e, pertanto, I'aumento di una delle due non equivale sistematicamente ad un incremento dell'altra.

Il tema della qualità urbana riveste un ruolo centrale nelle politiche di rigenerazione territoriale che mirano alla "COstruzione" di luoghi urbani accessibili, sicuri, esteticamente gradevoli, puliti e adeguatamente confortevoli.

Il progressivo allontanamento dei complessi produttivi verso le aree più periferiche delle città ha reso disponibili spazi urbani con localizzazioni strategiche per riprogettare la distribuzione delle funzioni sul territorio e per innalzare il livello della qualità percepita.

Sebbene non esista una definizione universalmente condivisa e generalizzabile di "qualità urbana", è riconosciuto il carattere gerarchico e multidimensionale di questo termine, connotato da diversi attributi che, a loro volta, sono declinati da aspetti più specifici (D'Acci, 2014). Tali fattori si riferiscono alla qualità ambientale, alla qualità dell'aria, alla presenza di spazi verdi, al lavoro, alle condizioni sociali, alla qualità dell'architettura, alla presenza di aree pedonali, ecc. e possono essere valutati mediante approcci

a) monetari (metodo dei prezzi edonici, disponibilità a pagare, rapporto costi-benefici, valore posizionale),

b) soggettivi (soddisfazione della vita e livello del benessere personale percepito),

c) quantitativi (analisi delle attrazioni urbane presenti e distribuzione delle stesse sul territorio).

La qualità dell'ambiente urbano non è ascrivibile ad una categoria univoca della quale sia possibile rilevare la pre- senza (o l'assenza), ma dipende da un complesso di fattori naturali, fisico-spaziali, funzionali, antropico-sociali e storico-culturali che concorrono, per quanto possibile, alla sua definizione (Agnoletti et al., 2014).

Molti ricercatori hanno provato ad interpretare e misurare il concetto di qualità della vita urbana: Richards et al. (2007) hanno studiato i fattori su cui intervenire per migliorare la qualità della vita dei residenti negli alloggi informali, nonché i principali ostacoli ad un innalzamento della qualità della vita nel Sud Africa; Clark e Kahn (1988) hanno stimato la disponibilità a pagare per servizi culturali urbani come musei, teatri, luoghi per la danza e la musica, zoo, concludendo che i benefici marginali derivanti da tali beni culturali sono compresi tra $\$ 85$ e \$54,9 milioni rispettivamente per un teatro e uno zoo in più; Lora et al. (2010), con riferimento ad otto città ubicate in sei Paesi dell'America Latina, hanno individuato i criteri per stabilire le priorità delle azioni politiche finalizzate al miglioramento del benessere sociale, al fine di determinare indicatori di valutazione dell'impatto di nuove strutture e di nuovi servizi pubblici sulla qualità della vita e sui prezzi delle abitazioni.

\subsection{Un modello per la valutazione della qualità urbana}

Il procedimento che si propone per la valutazione della qualità urbana prevede la disaggregazione di tale nozione nelle sue componenti. Ciascuna componente, poi, viene articolata e misurata tramite opportuni indicatori. È da evidenziare che questo approccio per la valutazione della qualità urbana deve tener conto di aspetti qualitativi e soggettivi, oltre che di elementi quantitativi e oggettivi.

Il modello messo a punto, inoltre, non intende giungere alla identificazione di un indice globale e sintetico della qualità urbana, bensì il suo obiettivo principale è di approfondire I'analisi dei differenti aspetti della qualità.

Il modello elaborato, pertanto, mira alla quantificazione degli indicatori di qualità urbana nello status quo e permette di stimare la variazione di qualità prevista a seguito di un intervento di trasformazione urbana.

L'articolazione delle fasi sviluppata mutua la scomposizione logica dalla Carta della Rigenerazione Urbana Audis 2008 (AA.VV., 2010, AUDIS, 2008, 2012)

In Tabella 1 sono riportate le sei componenti della qualità urbana individuate:

Tabella 1 - Componenti della qualità urbana Elaborazione degli Autori

QUALITÀ ARCHITETTONICA

QUALITÀ URBANISTICA

QUALITÀ AMBIENTALE

QUALITÀ PAESAGGISTICA

QUALITÀ DELLO SPAZIO PUBBLICO

QUALITÀ SOCIALE 
Gli indicatori selezionati nel presente studio per la quantificazione delle componenti della qualità urbana sono così classificabili:

- Indicatori oggettivi: attengono ad aspetti della qualità tangibili e misurabili. Con riferimento ad ogni componente, gli indicatori oggettivi mirano a verificare la presenza (o l'assenza) di elementi per valutare la qualità dei luoghi e a misurare i) le distanze da particolari elementi qualificanti o dequalificanti e ii) il livello di uno specifico aspetto della qualità sulla base di dati ufficiali.

- Indicatori soggettivi di tipo 1: fanno riferimento a punteggi attributi da team di esperti sociologi, paesaggisti, architetti, ambientalisti, ecc., al fine di valutare la capacità di un'area urbana di fornire standard qualitativi adeguati alla popolazione. Per ciascun indicatore compreso in tale categoria, si procede alla trasposizione di giudizi di soggetti "competenti" basati su scale verbali (ottimo, buono, scarso) in valori numerici compresi in scale di punteggi preliminarmente stabilite.

- Indicatori soggettivi di tipo 2: puntano a valutare gli aspetti della qualità urbana percepita. Con riferimento alle ricerche condotte da Bonaiuto et al. (2010), la valutazione di tale categoria di indicatori è espressa tramite giudizi numerici formulati da un campione sufficientemente rappresentativo dei fruitori della zona con riferimento agli aspetti soggettivi della qualità urbana, considerando, dunque, l'opinione della popolazione e/o dei frequentatori assidui ed occasionali dell'area urbana di cui si vuole valutare la qualità e declinando in termini quantitativi i giudizi espressi. L'operazione di traduzione delle percezioni soggettive personali in termini numerici prevede la formulazione di opportuni questionari e/o di sondaggi da sottoporre ad un campione di individui. La categoria degli indicatori soggettivi di tipo 2 permette di non limitare il processo di valutazione della qualità urbana esclusivamente al rispetto di standard urbanistici e/o di soglie minime fissate a livello generale, ma di esplicitare le percezioni personali dei soggetti che "vivono" uno spazio urbano e di riportarle sotto forma di giudizi sintetici e globali. Nel caso di specie è stato introdotto un questionario composto da una serie di espressioni verbali (item), riferite all'argomento valutato. Gli item sono caratterizzati da un'impostazione di senso affermativo o di senso negativo. La valutazione è espressa in termini quantitativi: a ciascuna espressione gli intervistati possono rispondere attraverso una gradazione numerica del giudizio variabile in un intervallo di valori prefissato (tra " 0 " e " 5 "), laddove il valore " 0 " individua un disaccordo totale con l'affermazione dell'item, mentre il valore " 5 " indica una condizione di accordo totale. La presenza, nell'ambito della stessa componente della qualità da valutare, di locuzioni positive e negative, pur complicando la compilazione del questionario da parte degli intervistati, permette di massimizzare la coerenza delle risposte.

A seguito della valutazione dei diversi item, la fase di aggregazione dei dati è effettuata impiegando tabelle di calcolo con le quali è possibile determinare i valori medi di ciascun aspetto della qualità urbana percepita sottoposto al vaglio. È opportuno che l'operazione tenga conto della presenza nel questionario di item di senso positivo e di altri di senso negativo. Secondo il già citato studio di Bonaiuto et al. (2010), ad esempio, gli item positivi vanno considerati per i relativi valori registrati durante la somministrazione del questionario, invece quelli negativi vanno rivalutati come differenza tra il valore massimo ed il punteggio attribuito dall'intervistato.

Il questionario per la presente ricerca è stato mutuato dalle conclusioni di Fornara et al. (2010), al fine di definire gli indicatori soggettivi di tipo 2 "ad hoc" per la valutazione della qualità urbana percepita (item). In Tabella 2 , per ciascuna delle sei componenti di qualità urbana, sono esplicitati gli indicatori proposti.

Tabella 2 - Indicatori proposti per la valutazione delle componenti della qualità urbana

\begin{tabular}{|c|c|c|}
\hline COMPONENTE & INDICATORI OGGETTIVI & INDICATORI SOGGETTIVI DI TIPO 1 \\
\hline $\begin{array}{l}\text { QUALITÀ } \\
\text { ARCHITETTONICA }\end{array}$ & $\begin{array}{l}\text { Distanza dell'immobile dall'elemento architettonico più } \\
\text { vicino }[\mathrm{km} \text { a piedi] }\end{array}$ & $\begin{array}{l}\text { Stato manutentivo delle facciate degli edi- } \\
\text { fici limitrofi }\end{array}$ \\
\hline $\begin{array}{l}\text { QUALITÀ } \\
\text { URBANISTICA }\end{array}$ & $\begin{array}{l}\text { Distanza dell'immobile } \\
\text { - dalla fermata autobus più vicina [km a piedi] } \\
\text { - dall'imbocco/sbocco alla strada a scorrimento veloce } \\
\text { [ } \text { - dalla stazion in auto] } \\
\text { - dalla fermata metro più vicina [km a piedi] } \\
\text { - dall'area adibita a parcheggio pubblico più vicina [km a } \\
\text { piedi] }\end{array}$ & Livello di mix funzionale del territorio \\
\hline
\end{tabular}

Segue Tabella 2 - Indicatori proposti per la valutazione delle componenti della qualità urbana 
Segue Tabella 2 - Indicatori proposti per la valutazione delle componenti della qualità urbana

\begin{tabular}{|c|c|c|}
\hline COMPONENTE & INDICATORI OGGETTIVI & INDICATORI SOGGETTIVI DI TIPO 1 \\
\hline $\begin{array}{l}\text { QUALITÀ } \\
\text { AMBIENTALE }\end{array}$ & $\begin{array}{l}\text { Distanza dell'immobile dall'area verde più vicina [km a } \\
\text { piedi] } \\
\text { Livello di inquinamento dell'aria della zona [Concentra- } \\
\text { zione media giornaliera di PM10, di PM2,5, di NO2, di } \\
\text { SO2 e di O3] }\end{array}$ & $\begin{array}{l}\text { Stato manutentivo dell'area verde più vi- } \\
\text { cina } \\
\text { Livello del traffico stradale } \\
\text { Livello dell'igiene complessiva della zona } \\
\text { urbana }\end{array}$ \\
\hline $\begin{array}{l}\text { QUALITÀ } \\
\text { PAESAGGISTICA }\end{array}$ & $\begin{array}{l}\text { Distanza da Landmark - emergenze architettoniche e } \\
\text { paesaggistiche riconosciute a livello collettivo [km a } \\
\text { piedi] }\end{array}$ & $\begin{array}{l}\text { Capacità del paesaggio di integrarsi con lo } \\
\text { spazio urbanizzato }\end{array}$ \\
\hline $\begin{array}{l}\text { QUALITÀ DELLO } \\
\text { SPAZIO PUBBLICO }\end{array}$ & $\begin{array}{l}\text { Presenza di minacce alla sicurezza nell'area [Numero di } \\
\text { crimini registrati nell'area nell'ultimo anno] }\end{array}$ & $\begin{array}{l}\text { Stato manutentivo degli elementi di ar- } \\
\text { redo urbano degli spazi pubblici }\end{array}$ \\
\hline QUALITÀ SOCIALE & $\begin{array}{l}\text { Dotazione di servizi di scala urbana } \\
\text { Distanza dell'immobile } \\
\text { - dalla biblioteca pubblica più vicina [km a piedi] } \\
\text { - dal centro sportivo pubblico più vicino [km a piedi] } \\
\text { - dal museo/teatro/cinema più vicino [km a piedi] } \\
\text { - dalla sede universitaria pubblica più vicina [km a piedi] } \\
\text { Dotazione di servizi educativi e culturali pubblici } \\
\text { Distanza dell'immobile } \\
\text { - dalla scuola materna pubblica più vicina [km a piedi] } \\
\text { - dalla scuola dell'obbligo pubblica più vicina [km a } \\
\text { piedi] } \\
\text { Dotazione di servizi commerciali } \\
\text { Distanza dell'immobile } \\
\text { - dal supermercato più vicino [km a piedi] } \\
\text { - dall'ufficio postale più vicino [km a piedi] } \\
\text { - dalla banca più vicina [km a piedi] } \\
\text { Dotazione di servizi per la salute e l'assistenza } \\
\text { Distanza dell'immobile dal centro di riposo più vicino } \\
\text { [km a piedi] } \\
\text { Strutture pubbliche dedicate all'assistenza sanitaria nella } \\
\text { zona [Numero] }\end{array}$ & $\begin{array}{l}\text { Dotazione di servizi di scala urbana } \\
\text { Livello qualitativo dei servizi di scala ur- } \\
\text { bana presenti nella zona } \\
\text { Dotazione di servizi educativi e culturali } \\
\text { pubblici } \\
\text { Livello qualitativo dei servizi educativi e } \\
\text { culturali pubblici presenti nella zona }\end{array}$ \\
\hline
\end{tabular}

\section{UN PROTOCOLLO PER L'ANALISI DEGLI EFFETTI DEGLI INTERVENTI DI TRASFORMAZIONE URBANA SUI VALORI IMMOBILIARI}

L'individuazione degli effetti sociali, funzionali, economici, ambientali che possono essere generati da un'iniziativa di trasformazione urbana, costituisce un'operazione utile per orientare le decisioni di governo del territorio. In tal senso il ruolo di indirizzo fornito dall'Estimo e dalla Valutazione dei progetti nei processi di trasformazione urbana e territoriale è opportuno in tutte le fasi del progetto (Agnoletti et al., 2014).

Nel quadro finora delineato, è di seguito proposto un protocollo procedurale per l'analisi degli effetti di interventi di trasformazione urbana sui valori immobiliari. Tale procedura si configura come una successione ordi- nata e sequenziale di operazioni (step) da compiere, e mira a fornire una prassi metodologico-operativa in grado di enucleare le ricadute di un progetto di riqualificazione urbana.

Lo strumento operativo che si propone vuole essere un modello teorico generalmente valido che può essere adoperato dalle Pubbliche Amministrazioni o da investitori di natura privata in qualsiasi contesto territoriale, al fine di supportare le fasi decisionali relative a un intervento sul territorio. Tale modello, infatti, prescinde dalle condizioni spaziali e temporali dello specifico caso di studio, e il suo corretto utilizzo dipende esclusivamente dalla quantità e dalla qualità dei dati disponibili. In Tabella 3 è riportato il protocollo che si propone dove, per ciascuna fase, sono illustrate le principali azioni da compiere. 
Un approccio metodologico innovativo per l'analisi degli effetti degli interventi di trasformazione urbana sui valori immobiliari

Tabella 3 - Protocollo per l'analisi degli effetti degli interventi di trasformazione urbana sui valori immobiliari

\begin{tabular}{|c|c|c|}
\hline FASE 1 & $\begin{array}{l}\text { Studio dell'intervento di trasformazione } \\
\text { urbana. }\end{array}$ & $\begin{array}{l}\text { 1.1 Inquadramento dell'intervento all'in- } \\
\text { terno del territorio comunale. } \\
\text { 1.2 Esplicitazione delle principali fun- } \\
\text { zioni previste e degli obiettivi gene- } \\
\text { rali del progetto. }\end{array}$ \\
\hline FASE 2 & $\begin{array}{l}\text { Raccolta dei dati nello status quo ante (si- } \\
\text { tuazione "ante intervento"). }\end{array}$ & $\begin{array}{l}\text { 2.1 Individuazione di un campione di im- } \\
\text { mobili, di prezzo e caratteri noti, ubi- } \\
\text { cati su tutto il territorio comunale o } \\
\text { distribuiti nelle differenti fasce/micro- } \\
\text { zone omogenee di mercato della } \\
\text { città. } \\
\text { 2.2 Individuazione delle variabili intrin- } \\
\text { seche ed estrinseche che influenzano } \\
\text { il valore di mercato degli immobili e } \\
\text { scelta della relativa modalità di valu- } \\
\text { tazione (scala di punteggi, distanza, } \\
\text { superficie, tempo/durata, ecc.). } \\
\text { 2.3 Valutazione del livello di qualità ur- } \\
\text { bana nello stato di fatto (situazione } \\
\text { "ante intervento"). } \\
\text { 2.4 Costruzione del database relativo allo } \\
\text { stato attuale mediante I'individua- } \\
\text { zione dei valori di ciascuna variabile } \\
\text { presa in esame e per ogni immobile } \\
\text { del campione. }\end{array}$ \\
\hline FASE 3 & $\begin{array}{l}\text { Applicazione della procedura econome- } \\
\text { trica nella situazione "ante intervento". }\end{array}$ & $\begin{array}{l}\text { 3.1 Individuazione della funzione che } \\
\text { lega i valori immobiliari ai fattori in- } \\
\text { trinseci ed estrinseci che concorrono } \\
\text { alla loro formazione nella situazione } \\
\text { attuale. }\end{array}$ \\
\hline FASE 4 & $\begin{array}{l}\text { Analisi dei legami funzionali ottenuti } \\
\text { nella situazione "ante intervento". }\end{array}$ & $\begin{array}{l}\text { 4.1 Determinazione del contributo mar- } \\
\text { ginale di ciascuna variabile (intrinseca } \\
\text { ed estrinseca) per esaminare I'inci- } \\
\text { denza percentuale della singola varia- } \\
\text { bile sui valori immobiliari nella situa- } \\
\text { zione "ante intervento". }\end{array}$ \\
\hline FASE 5 & $\begin{array}{l}\text { Valutazione del livello di qualità urbana } \\
\text { nella situazione "post intervento". }\end{array}$ & $\begin{array}{l}\text { 5.1 Applicazione del modello proposto } \\
\text { per la valutazione della qualità ur- } \\
\text { bana con riferimento all'ipotetico } \\
\text { stato futuro (situazione "post inter- } \\
\text { vento") ai fini della stima della modi- } \\
\text { fica dei valori delle variabili estrinse- } \\
\text { che. }\end{array}$ \\
\hline FASE 6 & $\begin{array}{l}\text { Determinazione dei nuovi valori immo- } \\
\text { biliari previsti nella situazione "post in- } \\
\text { tervento". }\end{array}$ & $\begin{array}{l}\text { 6.1 Sostituzione nella funzione indivi- } \\
\text { duata nel punto } 3.1 \text { (Fase } 3 \text { ) dei } \\
\text { "nuovi" valori delle variabili estrinse- } \\
\text { che che, a valle delle nuove funzioni } \\
\text { proposte, subiscono modifiche. }\end{array}$ \\
\hline FASE 7 & $\begin{array}{l}\text { Confronto dei valori stimati nelle situa- } \\
\text { zioni "ante" e "post intervento". }\end{array}$ & $\begin{array}{l}\text { 7.1 Per ciascuna zona di mercato omoge- } \\
\text { nea in cui è suddiviso il territorio co- } \\
\text { munale, raffronto tra i valori stimati } \\
\text { relativi allo stato attuale ed i valori sti- } \\
\text { mati riferiti allo stato "post inter- } \\
\text { vento". L'obiettivo è determinare gli }\end{array}$ \\
\hline
\end{tabular}

Segue Tabella 3 - Protocollo per l'analisi degli effetti degli interventi di trasformazione urbana sui valori immobiliari 
Segue Tabella 3 - Protocollo per I'analisi degli effetti degli interventi di trasformazione urbana sui valori immobiliari

\begin{tabular}{|c|c|c|}
\hline FASE 7 & $\begin{array}{l}\text { Confronto dei valori stimati nelle situa- } \\
\text { zioni "ante" e "post intervento". }\end{array}$ & $\begin{array}{l}\text { eventuali incrementi o decrementi } \\
\text { percentuali dei valori immobiliari } \\
\text { connessi all'attuazione del progetto } \\
\text { in esame. } \\
\text { 7.2 Identificazione ed illustrazione delle } \\
\text { possibili ragioni a base degli incre- } \\
\text { menti e/o dei decrementi ipotizzati al } \\
\text { fine di validarne la ragionevolezza e } \\
\text { la congruenza. }\end{array}$ \\
\hline FASE 8 & Sintesi dei risultati ottenuti. & $\begin{array}{l}\text { 8.1 Valutazione complessiva dei possibili } \\
\text { effetti previsti, non soltanto in termini } \\
\text { di variazione dei valori immobiliari, } \\
\text { ma anche in termini di innalzamento } \\
\text { del livello di qualità urbana, sociale ed } \\
\text { ambientale connessi all'intervento di } \\
\text { trasformazione. }\end{array}$ \\
\hline
\end{tabular}

\section{UN'APPLICAZIONE DEL PROTOCOLLO DI VALUTAZIONE}

Il protocollo di valutazione è qui implementato con riferimento a quattro interventi di trasformazione urbana in corso di attuazione nella città di Bari, capoluogo della regione Puglia.

Ciascun intervento ricade in una delle quattro fasce urbane della città (centrale, semicentrale, periferica, suburbana) delimitate dall' Osservatorio del Mercato Immobiliare (OMI) dell'Agenzia delle Entrate (http://www.agenziaentrate.gov.it/).

Gli interventi di trasformazione urbana selezionati sono differenti per ubicazione e tipologia. Riguardano, infatti, rispettivamente:

- un intervento di valorizzazione immobiliare da concretizzare nella fascia urbana centrale che concerne la realizzazione del Polo del Contemporaneo;

- un'iniziativa di riqualificazione e ampliamento dell'importante arteria stradale di via Giovanni Amendola nella fascia urbana semicentrale;

- la rigenerazione del fronte mare di San Girolamo nella fascia urbana periferica;

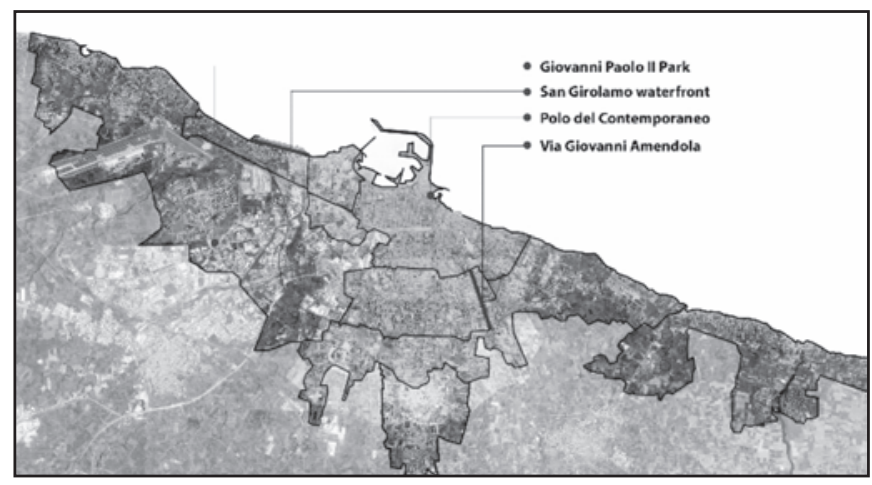

Figura 1 - Ubicazione degli interventi di trasformazione urbana presi in esame
- I'adeguamento e la messa in sicurezza del Parco Giovanni Paolo II nel quartiere San Paolo per la fascia suburbana.

In Figura 1 è mostrata l'ubicazione dei quattro interventi, ciascuno nella fascia $\mathrm{OMI}$ in cui insiste e, più in generale, nel territorio comunale del capoluogo pugliese.

\subsection{Descrizione dei casi studio}

\section{Intervento 1. La realizzazione del Polo del Contemporaneo}

\section{Descrizione dello stato attuale}

L'ubicazione centrale del Teatro Margherita, dell'edificio dell'ex Mercato del Pesce e di quello della Sala Murat - i tre compendi destinati a formare la sede del Polo del Contemporaneo - risulta strategica nei confronti del centro storico e, più in generale, dell'intera città.

II Teatro Margherita, realizzato tra il 1912 ed il 1914 e sottoposto a tutela dalla Soprintendenza ai Monumenti, è

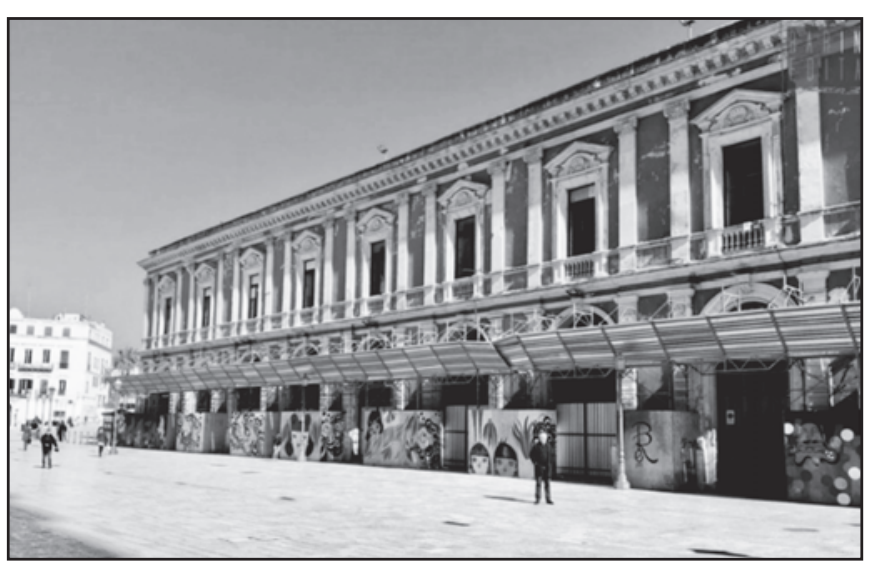

Figura 2 - L'edificio dell'ex Mercato del Pesce - situazione attuale 
Un approccio metodologico innovativo per l'analisi degli effetti degli interventi di trasformazione urbana sui valori immobiliari

uno dei teatri storici della città di Bari. Fino al 2009 il Teatro è stato oggetto di interventi di restauro statico e di ripristino delle facciate esterne, relativi al consolidamento delle fondazioni a mare e delle strutture portanti, alla sostituzione degli infissi e alla sistemazione dell'apparato decorativo del foyer.

L'edificio dell'ex Mercato del Pesce (Fig. 2) si presenta come un volume compatto a due piani, scandito da una ordinata partitura orizzontale e verticale. Dagli inizi del '900 fino agli anni Novanta, il piano terra dell'edificio ha ospitato il mercato del pesce, mentre il piano superiore è stato la sede del comando di polizia municipale. Nel corso degli ultimi anni, l'immobile è stato adibito, in un primo momento, a mercato ortofrutticolo e, successivamente, a bazar di vestiti, a pelletteria e al commercio di altre merci.

Intitolata a Gioacchino Murat, la Sala Murat ricalca la struttura del precedente Mercato della Carne, primo edificio pubblico della città costruito nel 1817 e demolito, per motivi di sicurezza (in quanto ormai fatiscente), nel secondo dopoguerra. L'edificio oggi presente è adibito a spazio espositivo.

\section{Il progetto di riqualificazione}

Il progetto del "Polo del Contemporaneo" (Fig. 3), siglato dall' Accordo di Valorizzazione Territoriale tra il Comune di Bari, la Regione Puglia e il Ministero dei Beni e delle Attività Culturali e del Turismo, mira a costituire un nuovo fulcro culturale multidisciplinare della città, quale attrattore per il turismo regionale, nazionale ed internazionale.

I tre edifici che ospiteranno il Polo diventeranno sede di eventi legati prevalentemente all'arte moderna e contemporanea.

Attualmente, il Teatro Margherita e I'ex Mercato del Pesce sono interessati da importanti opere di recupero e valorizzazione, in via di ultimazione. In particolare, l'intervento di completamento e recupero funzionale del

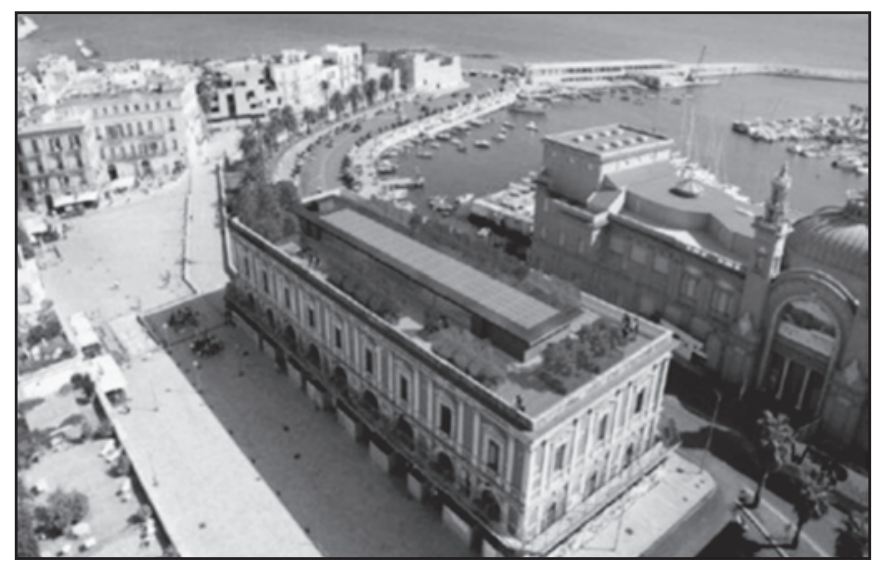

Figura 3 - L'edificio dell'ex Mercato del Pesce - situazione di progetto. A destra il Teatro Margherita
Teatro Margherita intende riportare l'edificio alla sua antica funzione di contenitore, in grado di ospitare manifestazioni di arte contemporanea e musicali.

L'intervento di riqualificazione dell'ex Mercato del Pesce prevede la riconversione funzionale dell'edificio, mediante la realizzazione, al piano terra, di un mercato dei prodotti tipici enogastronomici, artigianali e artistici locali sul modello dei mercati spagnoli; al primo piano, di uno spazio espositivo per le arti contemporanee, laboratori artistici, atelier, da concedere anche in fitto ai richiedenti, suite per residenze d'artista, nonché gli uffici del Polo del Contemporaneo; la terrazza, infine, verrà trasformata in un roof garden, ovvero in uno spazio verde strutturato come orto urbano, destinato ad accogliere eventi del mondo dell'arte, quali vernissage, inaugurazioni e anteprime.

\section{Intervento 2. L'allargamento dell'asse viario di via Giovanni Amendola}

\section{Descrizione dello stato attuale}

L'asse viario di via Giovanni Amendola (Fig. 4), lungo circa $3 \mathrm{~km}$ e perennemente congestionato, è una delle più importanti arterie di ingresso e di uscita dalla città di Bari.

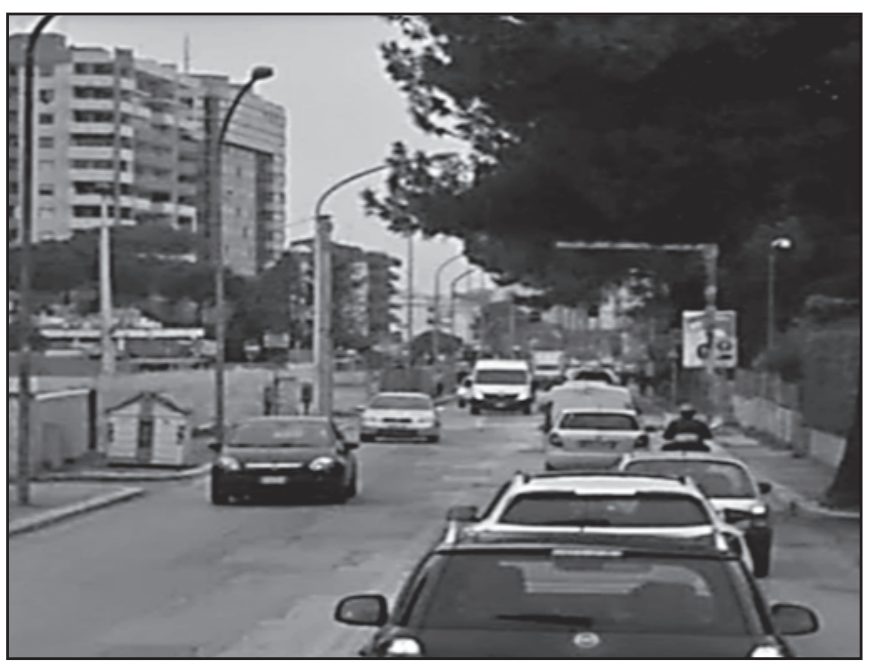

Figura 4 - Via Giovanni Amendola - situazione attuale

\section{Il progetto di riqualificazione}

Il progetto prevede l'ampliamento e la riqualificazione dell'asse viario di via Amendola, in particolare del tratto compreso tra via Conte Giusso e via Omodeo, per una lunghezza di circa $1,1 \mathrm{~km}$. I lavori riguardano differenti tipologie di opere, tra le quali: I'allargamento della carreggiata stradale sistemata con due corsie per senso di marcia e spartitraffico centrale; la realizzazione di tre rotatorie in corrispondenza di viale Einaudi, via Laforgia e via Hahnemann e di nuovi marciapiedi; I'inserimento 


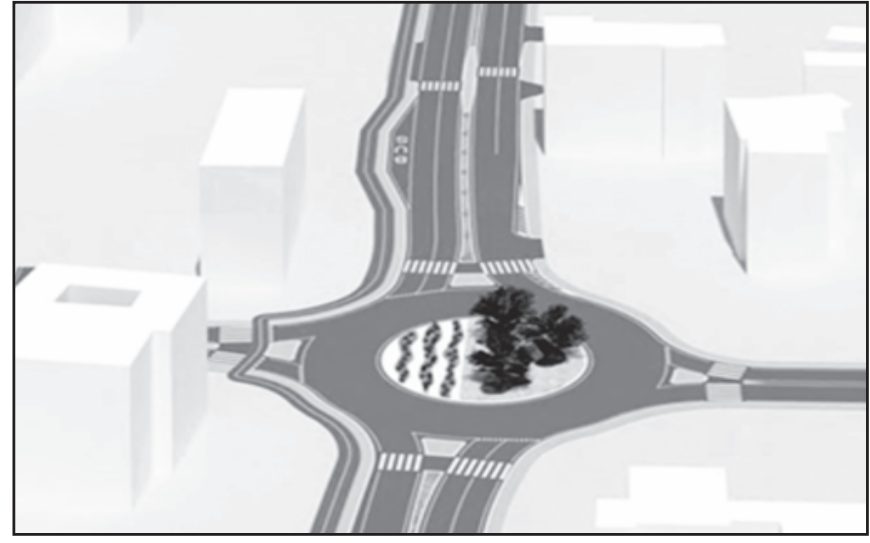

Figura 5 - Via Giovanni Amendola - situazione di progetto

sullo spartitraffico centrale di alberature e di nuovi attraversamenti pedonali e l'eliminazione dei semafori (Fig. 5). In definitiva, l'intervento mira alla realizzazione di una strada urbana più sostenibile ed efficiente, anche grazie all'inserimento di nuovi elementi di arredo urbano che possano rinnovare l'immagine di questa via di collegamento con la zona centrale.

\section{Intervento 3. La rigenerazione del fronte mare di San Girolamo}

\section{Descrizione dello stato attuale}

Collocato nell'omonimo quartiere, il fronte mare di San Girolamo si sviluppa per oltre un chilometro. L'imponente sviluppo edilizio a prevalente carattere residenziale che ha coinvolto l'intera area urbana a partire dalla fine degli anni Ottanta, ha comportato un notevole aumento dei fenomeni di congestione, senza risolvere quelli connessi alla marginalità della zona causata dall'assenza di un adeguato sistema infrastrutturale, in termini di viabilità e servizi (Fig. 6).

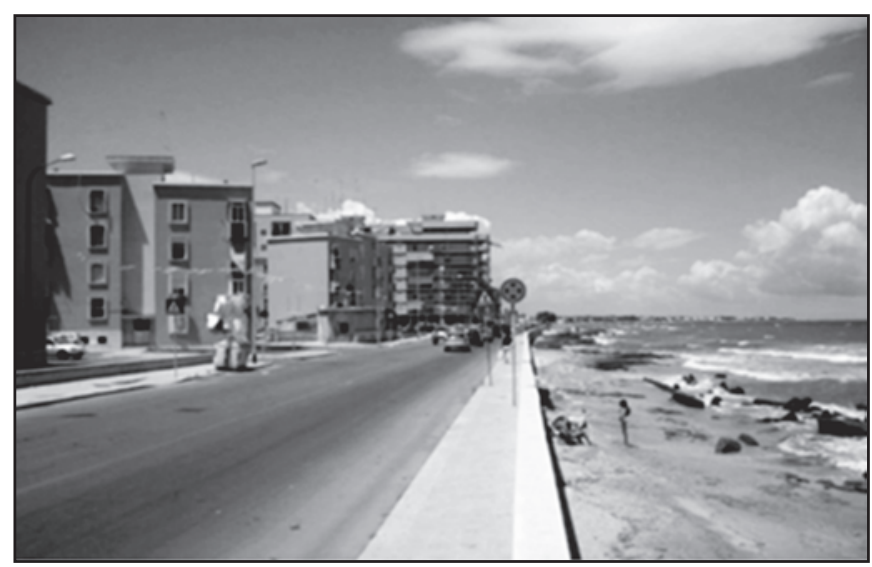

Figura 6 - Fronte mare di San Girolamo - situazione attuale
Attualmente, con riferimento all'intero quartiere, ed in particolare all'area prospiciente la costa, si rileva una notevole domanda di servizi non soddisfatta soprattutto per la mancanza di spazi pubblici quali "luoghi di socializzazione".

Le destinazioni commerciali ubicate in corrispondenza dei piani terra degli edifici lungo la linea costiera sono spesso inutilizzate, essendo il lungomare considerato e vissuto esclusivamente come un attraversamento veloce a margine della zona urbana piuttosto che come un asse di servizio del quartiere. Tale fenomeno contribuisce ad accentuare la marginalità del fronte mare rispetto alla zona interna del quartiere.

\section{Il progetto di riqualificazione}

L'intervento di riqualificazione del fronte mare di San Girolamo prevede il recupero e la trasformazione funzionale e paesaggistica del waterfront, con gli obiettivi di configurare un nuovo assetto paesaggistico e ambientale dell'affaccio a mare con nuove modalità d'uso degli spazi e di incidere sull'intero tessuto economico e sociale del quartiere.

La riqualificazione del fronte mare, così come mostrato in Figura 7, prevede la pedonalizzazione dello stesso con la creazione di una "piazza sul mare" di $8.000 \mathrm{~m}^{2}$ disposta su due livelli, con circa 600 posti a sedere fronte mare, e I'introduzione di nuove funzioni urbane quali: attività di servizio, luoghi per il tempo libero, lo sport, la balneazione e l'incontro sociale.

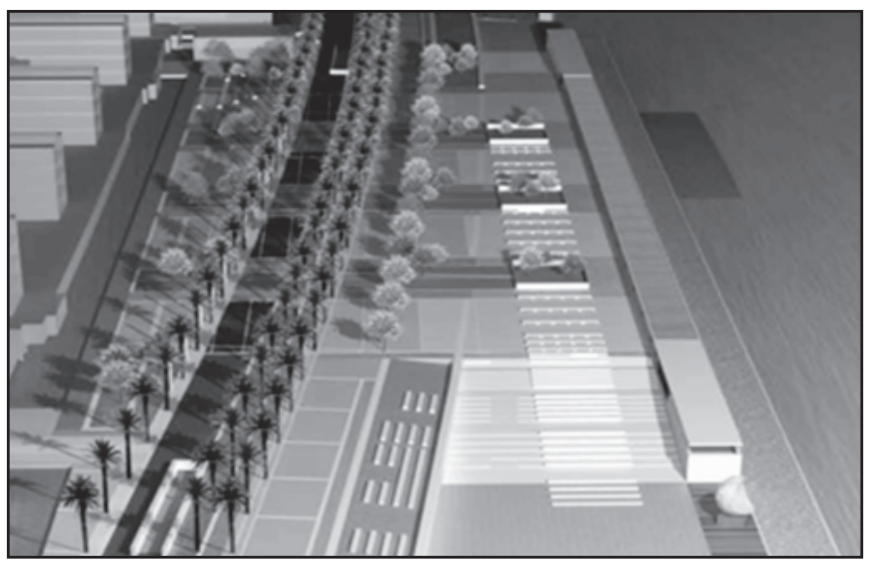

Figura 7 - Fronte mare di San Girolamo - situazione di progetto

\section{Intervento 4. La riqualificazione del Parco Giovanni Paolo II nel quartiere San Paolo}

Descrizione dello stato attuale

II "Parco Giovanni Paolo II" costituisce un'area verde della città di Bari, tra viale Europa e viale delle Regioni, nel quartiere San Paolo. 
Un approccio metodologico innovativo per l'analisi degli effetti degli interventi di trasformazione urbana sui valori immobiliari

Lo spazio è attualmente caratterizzato da un avanzato stato di degrado. Non è raro, attraversando il parco, rilevare porzioni di recinzioni divelte, lampioni di pubblica illuminazione non funzionanti o danneggiati, segnaletica interna al giardino deteriorata, parti in muratura rovinate e vandalizzate, attrezzature di arredo urbano degradate e bagni pubblici ormai inutilizzabili perché murati.

L'intero parco necessita di consistenti interventi di recupero dello spazio aperto e degli elementi ivi ubicati, nonché il ripristino della igiene e della sicurezza pubblica, al fine di rendere il giardino fruibile come spazio di svago, di aggregazione e di socializzazione.

Allo stato attuale, il parco risulta inutilizzato. Lo stato di incuria in cui versa da tempo (Fig. 8) non permette ai residenti del quartiere di usufruire di questa area né come area verde, e tanto meno come semplice attraversamento pedonale.

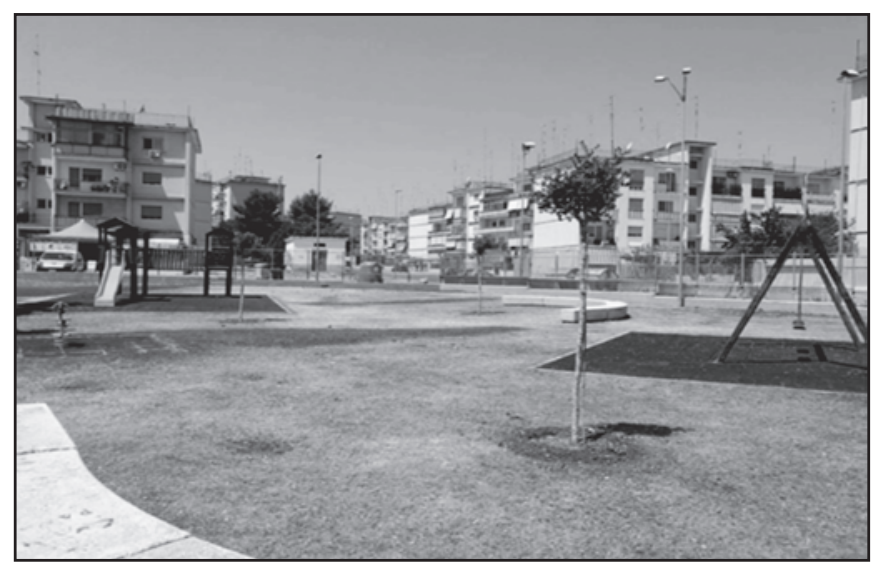

Figura 8 - Parco Giovanni Paolo II - situazione attuale

\section{Il progetto di riqualificazione}

Il progetto del Parco Giovanni Paolo II si inserisce nel più ampio programma di riqualificazione urbana che prevede quattordici parchi per l'area cittadina. Lo scopo di

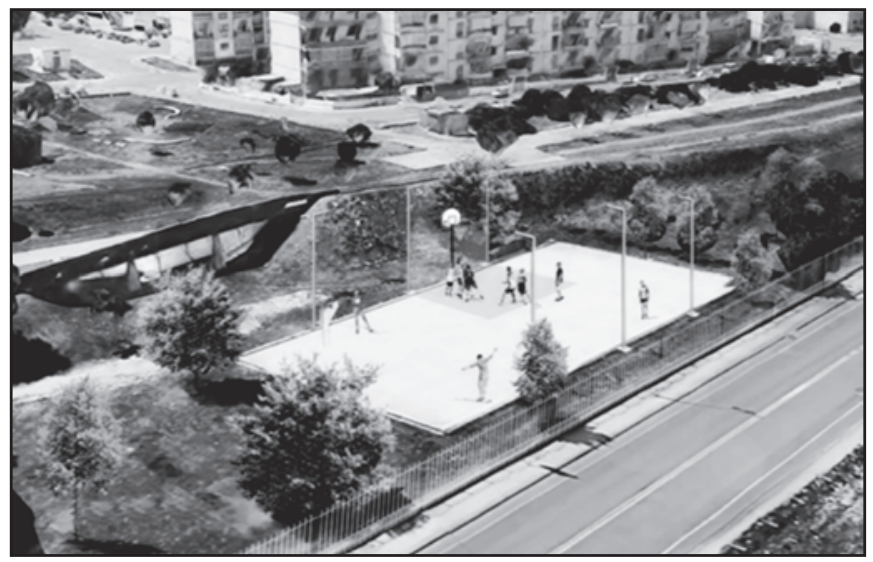

Figura 9 - Parco Giovanni Paolo II - situazione di progetto tali interventi è di dotare i quartieri di impianti e accessori per facilitare l'attività sportiva amatoriale, favorendo così la formazione di luoghi di incontro e di aggregazione, contrastando la marginalità sociale e la devianza. L'intervento del Parco Giovanni Paolo II (Fig. 9) mira al recupero dell'area che ospita la pista di pattinaggio, le cui condizioni di degrado incidono negativamente sul decoro del contesto urbano in cui è inserita.

\subsection{I dati raccolti}

Per ciascuna delle quattro fasce OMI in cui è suddivisa la città di Bari è stato raccolto un campione di duecento immobili a destinazione residenziale, compravenduti nel periodo 2017-2019 (in particolare dal secondo semestre 2017 al primo semestre 2019). Per ciascun immobile, sono stati rilevati il prezzo di compravendita e le caratteristiche intrinseche e estrinseche che, sulla base delle indicazioni fornite dagli agenti di mercato della zona e dei dati prodotti dall'Osservatorio del Mercato Immobiliare (OMI) dell'Agenzia delle Entrate, vengono ordinariamente prese in esame nelle fasi di contrattazione dagli operatori (venditori e acquirenti) locali (Bourassa et al., 2003).

\subsection{Le variabili del modello}

Con riferimento al modello da sviluppare e testare nella presente ricerca, la variabile dipendente è il prezzo totale di compravendita $(\mathrm{P})$, espresso in $€$ (euro).

I fattori relativi alla qualità urbana percepita sono valutati sottoponendo il questionario messo a punto per la ricerca, ad un campione di 200 soggetti per ciascuna fascia urbana OMI, selezionati in modo casuale (800 soggetti in totale). Il questionario è stato somministrato, dapprima, con riferimento alla situazione "ante intervento", al fine di misurare il livello di qualità urbana avvertita nello stato attuale e, successivamente, alla situazione "post intervento", allo scopo di valutare la variazione percepita del livello di qualità.

Sono di seguito descritte le variabili indipendenti prese in considerazione.

\section{Variabili intrinseche}

- Superficie commerciale totale dell'immobile calcolata in $\mathrm{m}^{2}-\mathrm{S}$;

- Numero di bagni presenti nell'immobile - B [n.];

- Livello di piano al quale l'immobile è ubicato - L [n.];

- Presenza dell'ascensore nello stabile in cui è ubicato I'immobile - A. La caratteristica è valutata come una variabile dummy (Hardy, 1993): il punteggio "1" indica la presenza dell'ascensore, il punteggio " 0 " l'assenza;

- Presenza del posto auto o del box auto - P. La variabile è valutata come dummy, laddove, il punteggio " 1 " indica la presenza del box auto, il punteggio " 0 " I'assenza. 
- Condizioni manutentive dell'immobile - Sc. La caratteristica è valutata come una variabile qualitativa ed è sintetizzata tramite un punteggio numerico: in particolare, è assegnato il punteggio " 1 " agli immobili le cui condizioni manutentive risultano pessime, il punteggio "3" a quelli caratterizzati da condizioni manutentive buone e il punteggio "5" agli immobili in condizioni manutentive ottime.

\section{Variabili estrinseche}

Con riferimento al procedimento seguito per la valutazione del livello di qualità urbana dell'area in cui si colloca ciascun immobile dei quattro campioni di studio, sono state impiegate le componenti di qualità (qualità architettonica, qualità urbanistica, qualità ambientale, qualità paesaggistica, qualità dello spazio pubblico, qualità sociale) e gli indicatori così come classificati nel paragrafo 3.2 della presente ricerca (indicatori oggettivi, indicatori soggettivi di tipo 1 e indicatori soggettivi di tipo 2). Di seguito, per ciascuna componente della qualità, si riportano gli indicatori oggettivi e soggettivi di tipo 1 selezionati, in quanto considerati maggiormente influenti nelle fasi di negoziazione tra i venditori e gli acquirenti che agiscono nel mercato residenziale nelle quattro fasce OMI della città di Bari. Ciascuna componente di qualità urbana percepita, riportata nel questionario, costituisce una variabile estrinseca da analizzare.

\section{Qualità Architettonica}

Indicatore soggettivo di tipo 1:

- Stato manutentivo delle facciate degli edifici limitrofi a quello oggetto di valutazione - Sf, valutato mediante una scala di punteggi attribuiti da un panel di esperti, laddove il punteggio " 1 " indica uno stato pessimo; il punteggio " 3 " indica uno stato buono ed il punteggio " 5 " uno stato ottimo.

\section{Qualità Urbanistica}

Indicatori oggettivi:

- Distanza dall'imbocco/sbocco dalla strada a scorrimento veloce (Tangenziale di Bari) più prossimo all'immobile di volta in volta considerato, misurata in chilometri da percorrere in auto - Dt;

- Distanza dalla stazione ferroviaria (Bari Centrale), misurata in chilometri da percorrere a piedi - Ds.

\section{Qualità Ambientale}

Indicatore oggettivo:

- Distanza dall'area verde più vicina all'immobile in analisi, misurata in chilometri da percorrere a piedi - Dv. Per i casi analizzati, le aree considerate risultano gli spazi di verde attrezzato, le piazze e i giardini pubblici maggiormente utilizzati dagli abitanti della città di Bari. In particolare, tali aree sono:
- Giardini di Piazza Umberto I - collocati nella fascia OMI centrale.

- Piazza Giuseppe Garibaldi - situata nella fascia OMI centrale.

- Parco 2 Giugno - situato nella fascia OMI semicentrale, a ridosso di quella centrale.

- Parco di Punta Perotti - appartenente alla fascia OMI centrale sul confine adiacente alla fascia periferica.

- Pineta San Francesco - collocata nella fascia OMI periferica.

- Pineta Giuseppe Romita - ubicata nella periferia nordovest della città di Bari nella fascia OMI suburbana.

Indicatore soggettivo di tipo 1:

- Livello di congestione del traffico veicolare privato e pubblico (autobus) della strada nella quale l'immobile è inserito - $T$, valutato mediante una scala di punteggi attribuiti da un team di esperti, laddove il punteggio " 1 " indica una strada caratterizzata da un'elevata intensità di traffico, il punteggio "3" afferisce ad una media intensità di traffico ed il punteggio " 5 " concerne una strada con una bassa congestione del traffico.

\section{Qualità Paesaggistica}

Indicatore oggettivo:

- Distanza dal principale Landmark urbano riconosciuto a livello collettivo (Lungomare Araldo di Crollalanza), misurata in chilometri da percorrere a piedi - Dl;

Qualità dello spazio pubblico

Indicatore soggettivo di tipo 1:

- Stato manutentivo degli elementi di arredo urbano (lampade da illuminazione pubblica, cestini porta rifiuti, panchine, fioriere, pensiline di sosta, tabelloni per cartelloni pubblicitari, ecc.) e degli spazi pubblici adiacenti all'immobile oggetto di valutazione - Sa. La variabile è valutata in termini qualitativi mediante una scala di punteggi attribuiti da esperti: il punteggio "1" indica uno stato pessimo, il punteggio " 3 " indica uno stato buono, il punteggio " 5 " indica uno stato ottimo.

\section{Qualità sociale:}

Indicatore oggettivo:

- Distanza dell'immobile dal mercato di generi alimentari più vicino, misurata in chilometri da percorrere a piedi - Dm.

\subsection{La tecnica econometrica}

La tecnica implementata per individuare, a partire dai dati del campione estimativo, la funzione dei prezzi di compravendita in ragione delle variabili che ne influenzano la misura, è la Evolutionary Polynomial Regression (EPR). 
La tecnica impiega un algoritmo genetico che esegue la combinazione di metodi di regressione numerica e simbolica utilizzando strutture polinomiali (Goldberg, 1989, Giustolisi et al., 2006). Nota la variabile dipendente $(Y)$ e le variabili indipendenti $\left(X_{i}\right)$, definiti i parametri utili per restituire la forma funzionale in grado di definire la relazione $Y=f\left(X_{j}\right)$, la generica espressione del modello non lineare implementato in EPR è sintetizzata dalla Eq. (1)

$$
Y=a_{0}+\sum_{i=1}^{n}\left[a_{i} \cdot\left(X_{1}\right)^{(i, 1)} \cdot \ldots \cdot\left(X_{j}\right)^{(i, j)} \cdot f\left(\left(X_{1}\right)^{(i, j+1)} \cdot \ldots \cdot\left(X_{j}\right)^{(i, 2, j)}\right)\right]
$$

dove $a_{0}$ è il termine costante, $n$ è il numero di termini additivi, ovvero la lunghezza dell'espressione polinomiale (costante esclusa), $a_{i}$ rappresenta il parametro moltiplicativo da determinare per ciascun termine additivo, $X_{i}$ è la variabile esplicativa candidata ad essere selezionata dal modello, $(i, I)-$ con $I=(1, \ldots, 2 j)$ - è l'esponente dell' I-esima variabile di input all'interno dell' $i$-esimo termine additivo, $f$ è una funzione individuata dall'utente all'interno di un set di possibili espressioni matematiche. Gli esponenti $(i, l)$ sono anch'essi selezionati dall'utente in un range di possibili numeri reali.

L'idea centrale di EPR è quella di ricercare la forma migliore della funzione, ossia una combinazione di vettori delle variabili indipendenti (le variabili scelte, inputs del modello) eseguendo una regressione con il Metodo dei Minimi Quadrati (Least Squares Method) per ottenere il valore dei coefficienti di ogni variabile. Le fasi che definiscono il processo di elaborazione econometrica sono: i) identificazione della struttura del modello ii) stima dei parametri. La quantità e la complessità delle soluzioni che la procedura genera dipendono dal numero massimo di termini ammesso e dagli esponenti che l'utente definisce nella fase preliminare all' elaborazione.

Una recente versione di EPR (Giustolisi et al. 2009), chiamata EPR-MOGA, riproduce un algoritmo genetico evolutivo multi-obiettivo, come strategia di ottimizzazione basata sulla frontiera di Pareto. La tecnica proposta è in grado di perseguire simultaneamente diverse funzioni obiettivo, tali da definire una frontiera paretiana ottimale degli obiettivi prefissati, in genere tra di loro conflittuali, quali:

i) la massimizzazione dell'accuratezza del modello, attraverso il soddisfacimento di appropriati indicatori statistici;

ii) la massimizzazione della parsimonia del modello, attraverso la minimizzazione del numero di coefficienti $\left(a_{j}\right)$ dell'equazione;

iii) la riduzione della complessità del modello, attraverso la minimizzazione del numero delle variabili esplicative $\left(X_{j}\right)$ dell'equazione finale.

Il fronte ottimale di Pareto che ne risulta contiene I'insieme dei migliori modelli matematici ottenuto considerando il miglior compromesso tra accuratezza del modello (obiettivo $i$ ) e complessità, vale a dire parsimonia dello stesso (obiettivo ii e obiettivo iii). La strategia di ot- timizzazione consente di ottenere, al termine della fase di modellazione, una serie di equazioni per i tre obiettivi considerati. In questo modo, viene offerta all'operatore una gamma di soluzioni, tra le quali è possibile selezionare quella più adatta in base alle esigenze del caso, alla conoscenza del fenomeno in analisi ed alla quantità e qualità di dati sperimentali utili per lo studio del campione. Il principale vantaggio di tale tecnica è che EPRMOGA restituisce un insieme di espressioni caratterizzate da un diverso livello di accuratezza statistica ed un differente grado di complessità della struttura matematica. È opportuno evidenziare che non è necessario postulare la forma "giusta" della struttura di modellazione prima dell'analisi, giacché è l'algoritmo implementato dalla procedura che genera differenti modelli. La scelta della soluzione di miglior compromesso tra la bontà statistica e la complessità dell'espressione è lasciata all'operatore, così da selezionare i modelli maggiormente adatti a seconda della situazione specifica.

Con riferimento alle applicazioni della tecnica EPRMOGA al settore del mercato immobiliare, le ricerche presenti in letteratura risultano molto poche e recenti (Morano et al., 2015, Tajani et al., 2015, Morano et al., 2018).

Nella presente ricerca è proposta e sperimentata una evoluzione ulteriore di EPR (che si aggiunge alle migliori performance ottenibili con il fronte paretiano previsto da EPR-MOGA), capace di sviluppare dei modelli di previsione generalizzati che identificano le relazioni funzionali in grado di descrivere contemporaneamente il meccanismo di formazione dei prezzi immobiliari in campioni di studio differenti (ad esempio, in diversi contesti territoriali). Questa tecnica, denominata Multi-Case Strategy per EPR (MCS-EPR), viene adoperata nelle situazioni in cui si intende studiare un fenomeno in casi/contesti differenti tra loro, al fine di rappresentarlo ed interpretarlo in maniera simultanea (Berardi et al., 2007, Savic et al. 2009). Disponendo di diversi casi di studio, ciascuno con il relativo set di dati, la tecnica MCS-EPR permette di definire una equazione "generalizzata" per la determinazione del prezzo, capace cioè di enucleare i fattori influenti tra quelli inizialmente considerati e le relative correlazioni funzionali, e valida per tutti i campioni analizzati (contesti territoriali). I campioni di studio possono riguardare ambiti urbani diversi appartenenti alla stessa città o aree geografiche appartenenti a città differenti poste sul territorio nazionale, per i quali si intende studiare l'incidenza di specifiche variabili esplicative sui valori immobiliari (Morano et al., 2019). Applicazioni di MCS-EPR presenti nella letteratura esistente (Giustolisi et al., 2007; Berardi et al., 2007) hanno dimostrato la capacità della tecnica di generare modelli robusti per la rappresentazione e l'interpretazione di fenomeni reali complessi.

La logica matematica della tecnica MCS-EPR impiega I'algoritmo genetico di EPR-MOGA per identificare i valori dei coefficienti polinomiali per tutti i campioni di dati 
considerati che soddisfano simultaneamente le tre funzioni obiettivo - massimizzazione della performance statistica, minimizzazione del numero dei coefficienti e minimizzazione del numero di variabili - per tutti i casi studio analizzati. Dunque, la strategia di MCS-EPR ricerca la struttura comune del modello, ovvero la combinazione delle variabili esplicative in grado di definire un modello generalizzato nella forma e valido per tutti i casi di studio. In funzione poi delle specificità di ciascun campione, I'algoritmo genetico di MCS-EPR restituisce coefficienti $-a_{0}$ ed $a_{i}$ in Eq. (1) - diversi, in ragione dei fenomeni (es. di mercato) che connotano i dataset dei differenti casi analizzati. In altre parole, le correlazioni funzionali (in termini assoluti) e le variabili esplicative delle equazioni restituite da MCS-EPR per i casi studio coincidono, mentre i coefficienti $\left(\mathrm{a}_{0}\right.$ ed $\left.\mathrm{a}_{j}\right)$ risultano differenti per ciascun campione considerato.

La performance statistica dell'analisi condotta da MCSEPR per ciascuna equazione del modello è verificata mediante diversi indicatori ( $\mathrm{R}^{2}$ corretto, AIC, RMSE) e test (ten-fold cross-validation). Inoltre, al fine di addivenire ad un modello che si adatti il più possibile ai diversi set di dati dei campioni, è calcolato un Coefficiente di determinazione generalizzato $\left(\mathrm{CoD}_{\mathrm{MCS}}\right)$, definito in Eq. (2):

$$
C o D_{M C S}=1-\frac{\sum_{k=1}^{m} \sum_{N_{k}}\left(y_{k}-y_{\text {rileuto }}\right)^{2}}{\sum_{N}\left(y_{\text {rileato }}-\bar{y}_{\text {rileato }}\right)^{2}}
$$

\begin{tabular}{|c|}
\hline $\begin{array}{c}\text { Eersione base } \\
\text { EPR } \\
\text { Massimizzazione della performance statistica } \\
\text { EPR-MOGA } \\
\text { - Minimizzazione del numero di coefficienti dell'equazione } \\
\text { - Riduzione della complessità del modello } \\
2^{\circ} \text { evoluzione } \\
\text { MCS-E PR } \\
\text { Forma funzionale generalizzata, } \\
\text { valida per differenticasi di studio }\end{array}$ \\
\hline
\end{tabular}

Figura 10 - Evoluzione della tecnica impiegata e degli obiettivi perseguiti laddove $\mathrm{m}$ è il numero di campioni di dati per i quali è richiesto un modello di previsione generalizzato $(k=1$, $\ldots, m) ; N_{k}$ è la dimensione (cioè il numero di individui) del $k$-esimo campione di dati; $N$ è il numero totale di individui che costituiscono tutti gli $m$ campioni di dati in analisi; $y_{k}$ è il valore della variabile dipendente stimata dalla tecnica attraverso l'inferenza statistica sul vettore

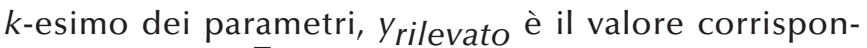
dente rilevato e $\bar{y}_{\text {rilevato }}$ è il valore medio dei valori raccolti nei campioni di dati $m$. Al pari di un classico Coefficiente di determinazione, quanto più il CoDMCS è prossimo al valore unitario, tanto più la struttura del modello restituito da MCS-EPR è idonea a rappresentare I'insieme complessivo dei dati dei diversi campioni.

In Figura 10 è sintetizzata l'evoluzione della tecnica econometrica impiegata e degli obiettivi perseguiti dall'algoritmo genetico sottostante.

\subsection{Determinazione del modello generalizzato nella situazione "ante intervento"}

La tecnica MCS-EPR è stata inizialmente implementata sui quattro casi studio nella situazione "ante intervento". Per tutti i campioni, la variabile dipendente è costituita dal logaritmo naturale del prezzo di compravendita $(\mathrm{Y}=$ $\ln (\mathrm{P}))$, coerentemente con quanto suggerito in diverse ricerche (Lynch et al., 2004).

L'applicazione della tecnica ha restituito diverse funzioni. Tra esse, il modello generalizzato scelto è riportato in Eq. (3), caratterizzato da un elevato livello di attendibilità statistica, confermata sia dagli indicatori statistici classici, sia dal valore di CoD ${ }_{\text {MSC }}$ pari a $84,18 \%$.

$$
\begin{aligned}
& Y=a_{0}+a_{1} \cdot D s^{0.5} \cdot Q u^{0.5} \cdot Q n^{0.5}+a_{2} \cdot S c^{0.5} \cdot D I \\
& 0.5 \cdot Q a^{0.5} \cdot Q n \cdot Q s+a_{3} \cdot S c+a_{4} \cdot A^{0.5} \cdot D s^{0.5} \cdot \\
& Q p^{0.5}+{ }_{+} a_{5} \cdot L^{0.5} \cdot Q n^{0.5}+a_{6} \cdot B^{0.5} \cdot S a^{0.5} \cdot T^{0.5} \cdot \\
& Q n^{2} \cdot Q s^{2}++a_{7} \cdot S^{0.5}+a_{8} \cdot S
\end{aligned}
$$

Le variabili esplicative identificate dall'algoritmo genetico implementato in Eq. (3) sono le seguenti: distanza dalla stazione ferroviaria (Ds), qualità urbanistica percepita $(\mathrm{Qu})$, qualità dell'ambiente naturale percepita $(\mathrm{Qn})$, stato conservativo dell'immobile (Sc), distanza dal Landmark (DI), qualità architettonica percepita (Qa), qualità sociale percepita (Qs), presenza dell'ascensore (A), qua-

Tabella 4 - Parametri del modello generalizzato per ciascuna fascia OMI della città di Bari

\begin{tabular}{|c|c|c|c|c|c|c|c|c|c|}
\hline FASCIA OMI & $\mathbf{a}_{\mathbf{0}}$ & $\mathbf{a}_{\mathbf{1}}$ & $\mathrm{a}_{\mathbf{2}}$ & $\mathrm{a}_{\mathbf{3}}$ & $\mathrm{a}_{\mathbf{4}}$ & $\mathrm{a}_{\mathbf{5}}$ & $\mathrm{a}_{\mathbf{6}}$ & $\mathrm{a}_{\mathbf{7}}$ & $\mathrm{a}_{\mathbf{8}}$ \\
\hline SUBURBANA & +7.09 & +1.53 & -2.73 & 0.82 & 0.41 & 0 & 2.02 & 11.25 & -7.87 \\
\hline PERIFERICA & +8.32 & +1.69 & 0 & 0.35 & 0.65 & 0 & 5.66 & 6.34 & -2.76 \\
\hline SEMICENTRALE & +9.84 & 0 & 0 & 0.47 & 0.52 & 0 & 0 & 3.33 & 0 \\
\hline CENTRALE & +8.74 & -2.84 & 0 & 0.55 & 1.48 & 0 & 3.06 & 7.61 & -3.69 \\
\hline
\end{tabular}


Un approccio metodologico innovativo per l'analisi degli effetti degli interventi di trasformazione urbana sui valori immobiliari

lità dello spazio pubblico percepita $(\mathrm{Qp})$, livello di piano al quale è collocato $\mathrm{I}^{\prime} i m m o b i l e(\mathrm{~L})$, numero di bagni presenti nell'unità immobiliare (B), stato manutentivo degli elementi di arredo urbano degli spazi pubblici prossimi all'immobile (Sa), livello di congestione del traffico nell'area in cui è ubicato il bene $(\mathrm{T})$, superficie totale dell'immobile (S).

Rispetto alle variabili esplicative inizialmente ipotizzate come fattori influenti sulla formazione del prezzo di compravendita per le quattro fasce urbane della città di Bari, il modello generalizzato di Eq. (3) non contempla cinque variabili: distanza dallo spazio verde più vicino all'immobile (Dv), presenza del posto auto di pertinenza dell'unità immobiliare $(\mathrm{P})$, distanza dal mercato di generi alimentari più vicino $(\mathrm{Dm})$, stato manutentivo delle facciate degli edifici limitrofi (Sf), distanza dall'imbocco/sbocco della strada a scorrimento veloce più vicino all'immobile (Dt).

Stante dunque la forma funzionale unica, valida per i quattro casi studio, in Tabella 4 sono riportati i valori dei coefficienti moltiplicativi per ciascuna fascia OMI analizzata.

In Tabella 5 sono esplicitate le quattro equazioni per le fasce OMI in cui è suddivisa la città di Bari.

Si osserva che lo stato conservativo dell'immobile (Sc), la presenza dell'ascensore (A), la distanza dalla stazione ferroviaria (Ds), la qualità dello spazio pubblico percepita $(\mathrm{Qp})$ e la superficie totale dell'immobile (S) compaiono in tutte e quattro le equazioni con un coefficiente moltiplicativo diverso da zero. Per gli altri fattori del modello generalizzato si verifica un comportamento di mercato diverso per ciascuno dei campioni analizzati.

Con riferimento alle variabili di qualità urbana percepita, l'equazione relativa al campione di studio della fascia OMI suburbana contempera tutte le caratteristiche correlate alla qualità dello spazio urbano - qualità urbanistica percepita $(\mathrm{Qu})$, qualità sociale percepita $(\mathrm{Qs})$, qualità dello spazio pubblico percepita $(\mathrm{Qp})$, qualità dell'ambiente naturale percepita $(\mathrm{Qn})$ e qualità architettonica percepita $(\mathrm{Qa})$; nelle equazioni ottenute per i campioni di studio delle fasce OMI periferica e centrale, le variabili
Qu (qualità urbanistica percepita), Qn (qualità dello spazio naturale percepita), Qp (qualità dello spazio pubblico percepita) e Qs (qualità sociale percepita) sono individuate come influenti, mentre per Qa (qualità architettonica percepita) non si riscontra un apprezzamento nei due mercati di riferimento; infine, l'equazione relativa al campione di studio della fascia OMI semicentrale seleziona esclusivamente la variabile Qp (qualità dello spazio pubblico percepita).

Nelle Figure 11, 12, 13 e 14 sono rappresentate le correlazioni funzionali per ciascuna fascia OMI della città di Bari, tra i prezzi di compravendita e le caratteristiche relative al livello di qualità urbana.

\subsection{Valutazione del livello di qualità urbana nella situazione "post intervento"}

Ciascuno dei quattro interventi considerati nella presente ricerca genera una variazione del livello di qualità urbana dell'area oggetto di trasformazione e del contesto circostante. Nelle espressioni funzionali ottenute mediante l'implementazione della tecnica MCS-EPR sui dati originari (situazione "ante intervento"), questo fenomeno si traduce in una modifica dei valori delle variabili estrinseche selezionate dal modello generalizzato. La determinazione dei nuovi valori delle variabili per cui si prevede una variazione a seguito della realizzazione di ciascun intervento è effettuata mediante l'impiego dei criteri illustrati (si veda il paragrafo 3.2) e altresì già delineati nel presente lavoro (indicatori oggettivi, indicatori soggettivi di tipo 1 e indicatori soggettivi di tipo 2). Per la valutazione degli indicatori della qualità percepita, il questionario è stato somministrato al medesimo campione di individui interrogato per la misurazione della qualità percepita nella situazione "ante intervento". A valle della illustrazione di ogni progetto analizzato per ogni fascia OMI della città di Bari, a ciascun soggetto è stato richiesto di formulare un giudizio-di previsione sulla variazione di qualità percepita prefigurando l'area urbana oggetto di valutazione nella situazione "post intervento".

Tabella 5 - Equazioni relative a ciascuna fascia OMI della città di Bari

\begin{tabular}{|c|c|}
\hline FASCIA OMI & MODELLO \\
\hline SUBURBANA & $\begin{array}{l}Y=+1.53 \bullet \mathrm{Ds}^{0.5} \bullet \mathrm{Qu}^{0.5} \bullet \mathrm{Qn}^{0.5}-2.73 \bullet \mathrm{Sc}^{0.5} \bullet \mathrm{DI}^{0.5} \bullet \mathrm{Qa}^{0.5} \bullet \mathrm{Qn} \bullet \mathrm{Qs}+0.82 \bullet \mathrm{Sc}+0.41 \bullet \mathrm{A}^{0.5} \bullet \mathrm{Ds}^{0.5} \bullet \\
\bullet \mathrm{Qp}^{0.5}+2.02 \bullet \mathrm{B}^{0.5} \bullet \mathrm{Sa}^{0.5} \bullet \mathrm{T}^{0.5} \mathrm{Qn}^{2} \bullet \mathrm{Qs}^{2}+11.25 \bullet \mathrm{S}^{0.5}-7.87 \bullet \mathrm{S}+7.09\end{array}$ \\
\hline PERIFERICA & $\begin{array}{l}Y=+1.69 \bullet \mathrm{Ds}^{0.5} \bullet \mathrm{Qu}^{0.5} \bullet \mathrm{Qn}^{0.5}+0.35 \bullet \mathrm{Sc}+0.65 \bullet \mathrm{A}^{0.5} \bullet \mathrm{Ds}^{0.5} \bullet \mathrm{Qp}^{0.5}+5.66 \bullet B^{0.5} \bullet \mathrm{Sa}^{0.5} \bullet \mathrm{T}^{0.5} \mathrm{Qn}^{2} \bullet \mathrm{Qs}^{2}+ \\
+6.34 \bullet \mathrm{S}^{0.5}-2.76 \bullet S+8.32\end{array}$ \\
\hline SEMICENTRALE & $Y=+0.47 \bullet S C+0.52 \bullet A^{0.5} \bullet D s{ }^{0.5} \bullet Q p^{0.5}+3.33 \bullet S^{0.5}+9.84$ \\
\hline CENTRALE & $\begin{array}{l}Y=-2.84 \bullet \mathrm{Ds}^{0.5} \bullet \mathrm{Qu}^{0.5} \bullet \mathrm{Qn}^{0.5}+0.55 \bullet \mathrm{Sc}+1.48 \bullet \mathrm{A}^{0.5} \bullet \mathrm{Ds}^{0.5} \bullet \mathrm{Qp}^{0.5}+3.06 \bullet B^{0.5} \bullet \mathrm{Sa}^{0.5} \bullet \mathrm{T}^{0.5} \mathrm{Qn}^{2} \bullet \mathrm{Qs}^{2}+ \\
+7.61 \bullet \mathrm{S}^{0.5}-3.69 \bullet \mathrm{S}+8.74\end{array}$ \\
\hline
\end{tabular}




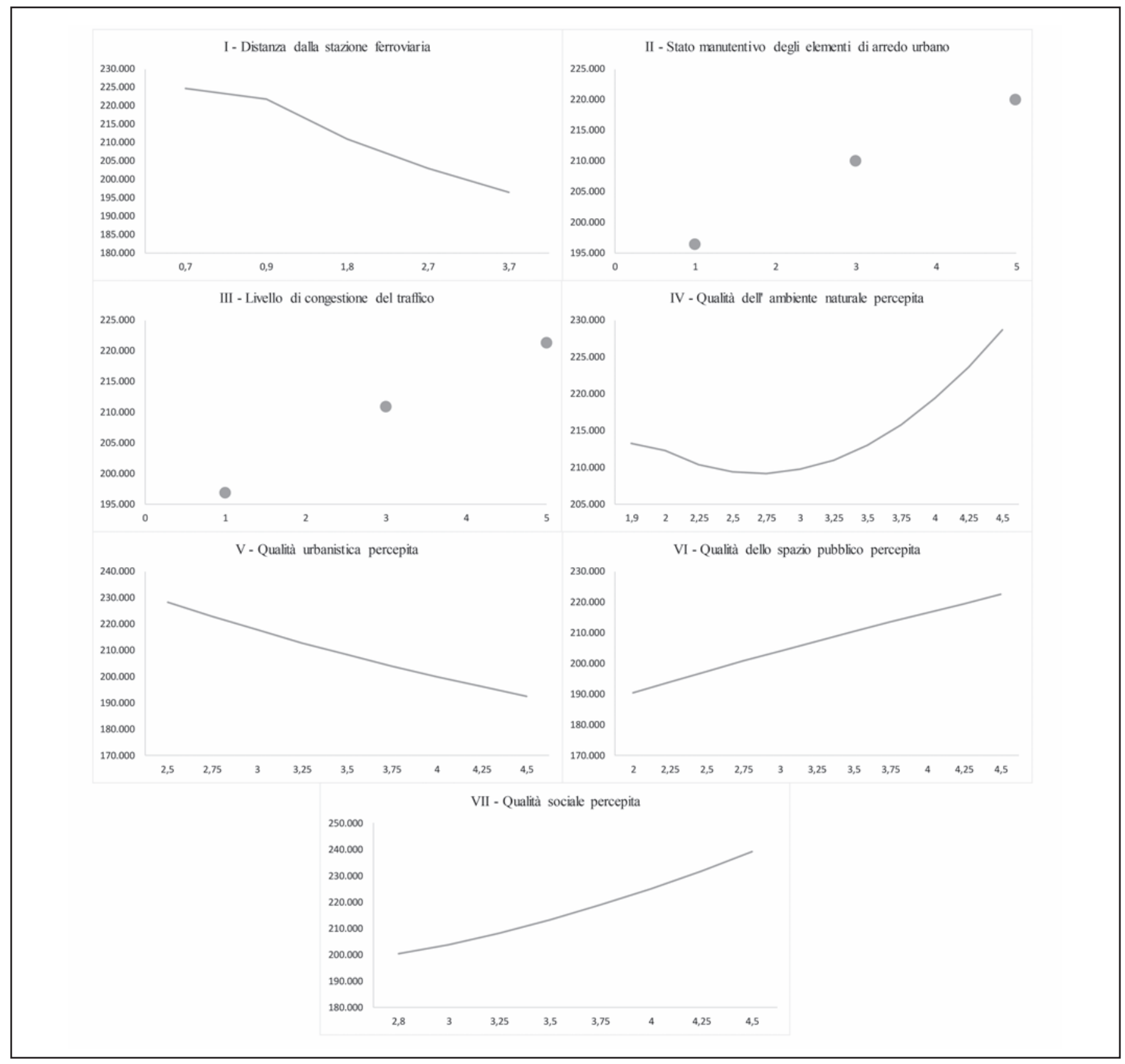

Figura 11 - Legami funzionali tra i valori immobiliari e le variabili estrinseche selezionate dal modello generalizzato per la fascia OMI centrale

\subsection{Determinazione dei valori immobiliari nella situazione "post intervento"}

Il procedimento adottato per la valutazione degli effetti di ciascun intervento di trasformazione urbana sui valori immobiliari si fonda sull'ipotesi che le relazioni funzionali esplicitate nel modello generalizzato ottenuto per la situazione "ante intervento" (Eq.(3)) non varino a seguito della realizzazione di ciascun progetto.

Si assume, pertanto, che gli interventi da realizzare in cia- scuna fascia OMI della città di Bari non generino modifiche dell'intero sistema urbano e che, quindi, le dinamiche strutturali del mercato immobiliare, in particolare del settore residenziale, restino invariate, ossia che i fattori che intervengono nei processi di formazione dei prezzi nella situazione "post riqualificazione" non mutino rispetto a quelli considerati nella situazione "ante intervento".

Si tratta evidentemente di una ipotesi forte.

In virtù di questa ipotesi, tuttavia, è possibile impiegare le equazioni precedentemente ottenute (Tab. 5) per la de- 
Un approccio metodologico innovativo per l'analisi degli effetti degli interventi di trasformazione urbana sui valori immobiliari

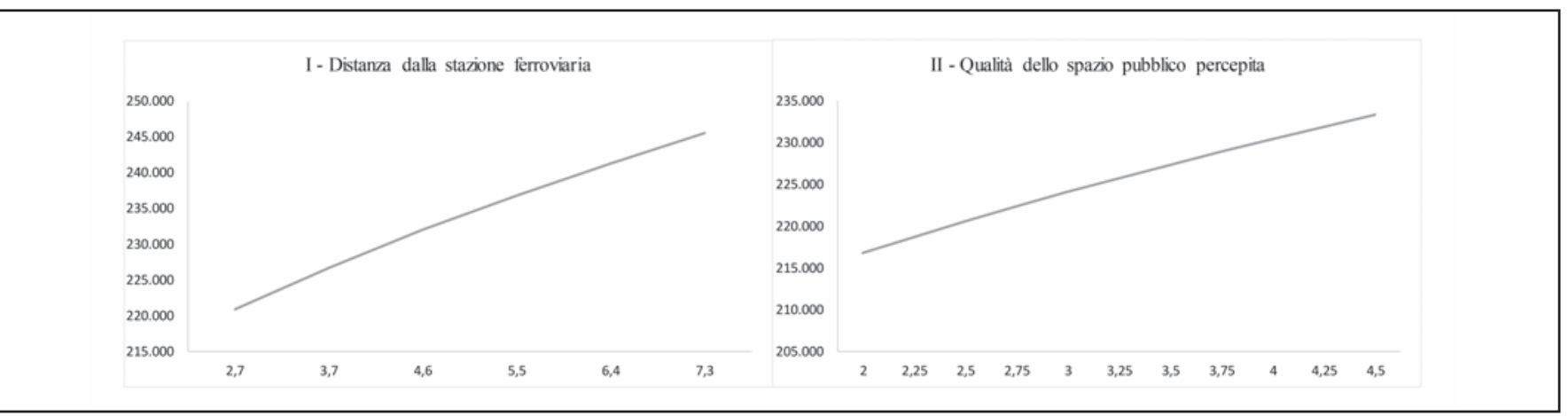

Figura 12 - Legami funzionali tra i valori immobiliari e le variabili estrinseche selezionate dal modello generalizzato per la fascia OMI semicentrale

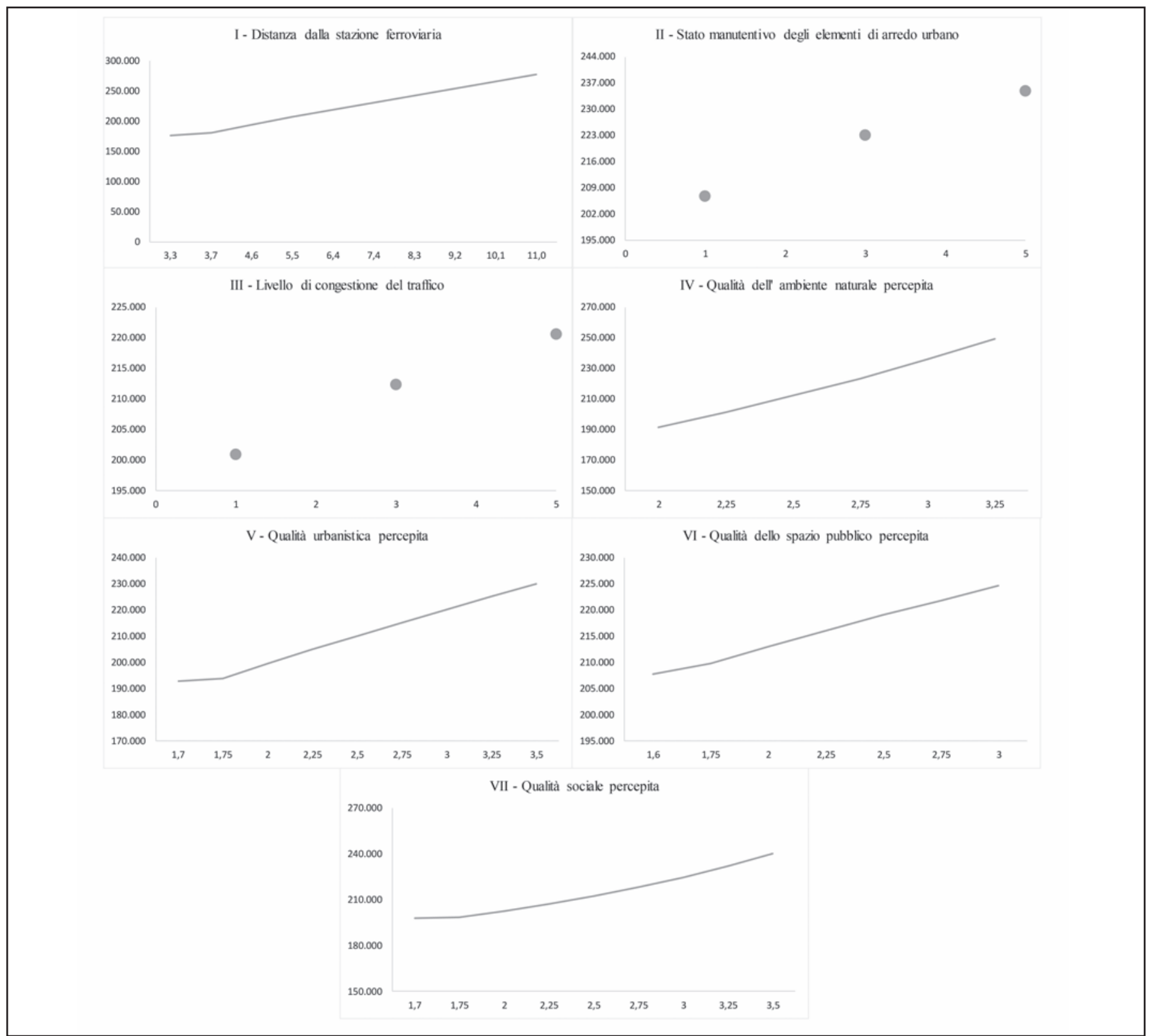

Figura 13 - Legami funzionali tra i valori immobiliari e le variabili estrinseche selezionate dal modello generalizzato per la fascia OMI periferica 


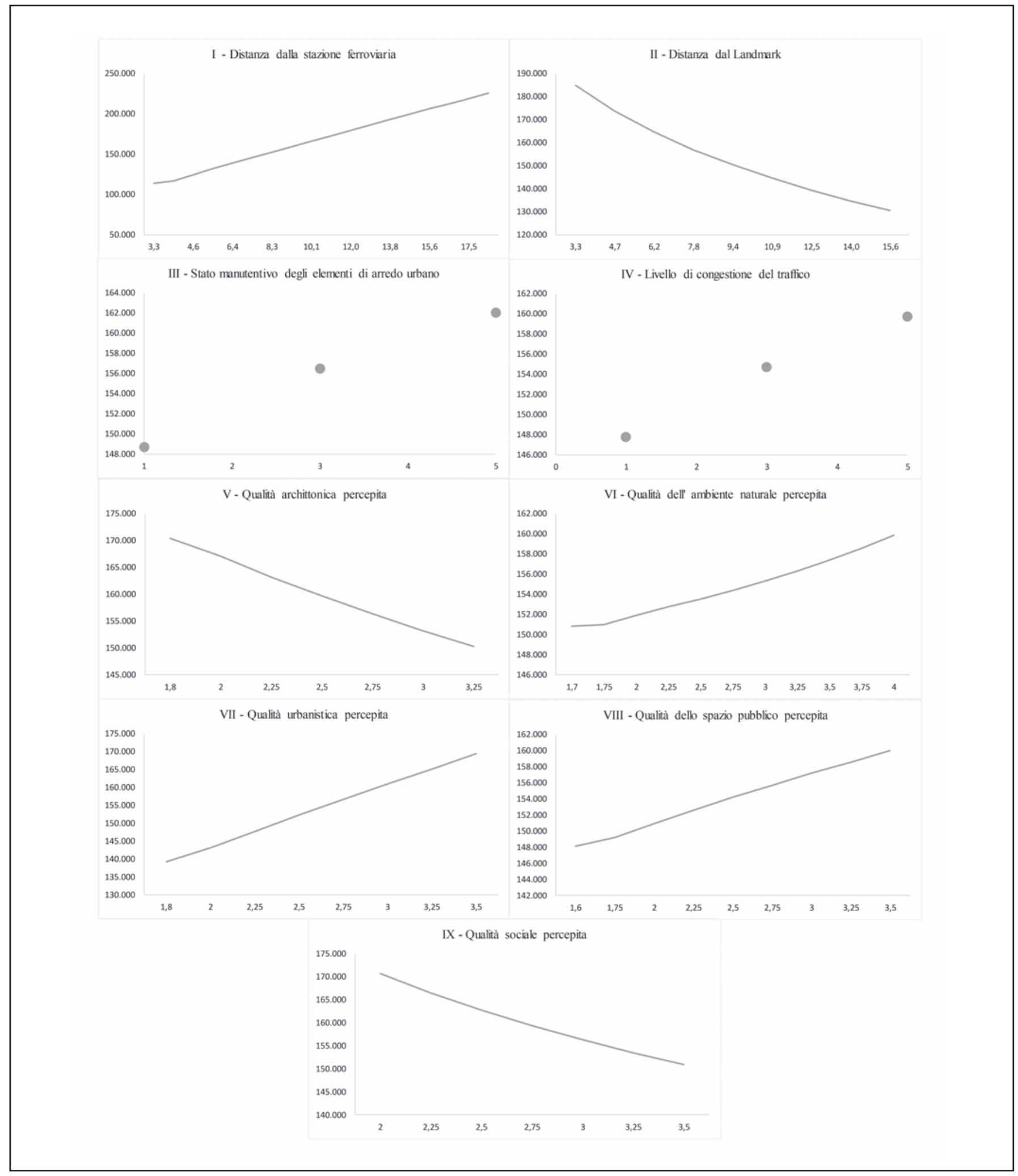

Figura 14 - Legami funzionali tra i valori immobiliari e le variabili estrinseche selezionate dal modello generalizzato per la fascia OMI suburbana 
Un approccio metodologico innovativo per l'analisi degli effetti degli interventi di trasformazione urbana sui valori immobiliari

terminazione dei valori immobiliari nella situazione "post intervento", introducendo le variazioni di valore delle caratteristiche di qualità urbana stimate per la realizzazione dei progetti in analisi.

In Tabella 6 sono richiamate le quattro espressioni matematiche della funzione del prezzo per le fasce OMI della città di Bari, evidenziando (in grassetto) le variabili relative alla qualità urbana per cui, a seguito del progetto, si prevede una variazione dei valori.

\subsection{Confronto dei valori stimati nelle situazioni "ante intervento" e "post intervento"}

Per ciascuna fascia OMI della città di Bari, nelle Figure 15, 16, 17 e 18 è rappresentata la propagazione degli effetti derivanti dalla realizzazione di ciascuno dei quattro interventi di trasformazione urbana sui valori immobiliari.

Le fasce OMI semicentrale, periferica e suburbana della città di Bari sono costituite da zone urbane discontinue: si tratta di ambiti che, seppure spazialmente slegati, sono caratterizzati - allo stato attuale - da fenomeni mercantili simili secondo le dinamiche delineate dall'Agenzia delle Entrate.

Gli output delle analisi condotte si prestano ad interessanti considerazioni.

In tutti i casi, i risultati ottenuti evidenziano un'influenza significativa sugli immobili prossimi all'area di intervento ed uno smorzamento degli effetti di mercato sulle zone più distanti, coerentemente con i fenomeni empirici normalmente attesi.

Il grafico di Figura 15 mostra per la fascia OMI centrale una variazione dei valori immobiliari maggiormente consistente per le abitazioni poste nelle immediate vicinanze dell'intervento; I'effetto di propagazione si attenua al crescere della distanza dall'area in questione, e diventa nullo per gli immobili distanti dal quartiere Murattiano nel quale ricadono i tre edifici di progetto. Si osserva invece che nel borgo antico della città, collocato a Nord del centro urbano, sebbene prossimo all'intervento di riqualifi-

Tabella 6 - Individuazione delle variabili relative alla qualità urbana per cui, nella situazione "post intervento", si prevede una variazione dei valori nei quattro modelli ottenuti per ciascuna fascia OMI della città di Bari

\begin{tabular}{|c|c|}
\hline FASCIA OMI & MODELLO \\
\hline SUBURBANA & 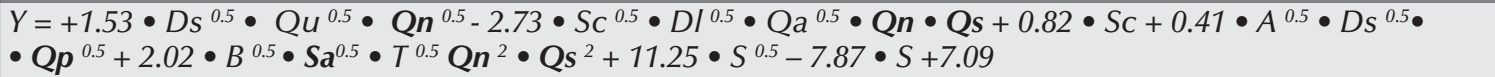 \\
\hline PERIFERICA & $\begin{array}{l}Y=+1.69 \bullet D s^{0.5} \bullet Q u^{0.5} \bullet Q n^{0.5}+0.35 \bullet S c+0.65 \bullet A^{0.5} \bullet D s^{0.5} \bullet Q p^{0.5}+5.66 \bullet B \\
\bullet T^{0.5} \mathrm{Qn}^{2} \bullet Q s^{2}+6.34 \bullet S^{0.5}-2.76 \bullet S+8.32\end{array}$ \\
\hline SEMICENTRALE & $Y=+0.47 \bullet S c+0.52 \bullet A^{0.5} \bullet D s^{0.5} \bullet Q p^{0.5}+3.33 \bullet S^{0.5}+9.84$ \\
\hline CENTRALE & $\begin{array}{l}Y=-2.84 \bullet \mathrm{Ds}^{0.5} \bullet Q u^{0.5} \bullet \mathrm{Qn}^{0.5}+0.55 \bullet \mathrm{Sc}+1.48 \bullet A^{0.5} \bullet \mathrm{Ds}{ }^{0.5} \bullet \mathrm{Qp}^{0.5}+3.06 \bullet B^{0.5} \bullet \mathrm{Sa}^{0.5} \bullet \boldsymbol{T}^{0.5} \mathrm{Qn}^{2} \bullet Q \boldsymbol{s}^{2}+ \\
+7.61 \bullet \mathrm{S}^{0.5}-3.69 \bullet \mathrm{S}+8.74\end{array}$ \\
\hline
\end{tabular}

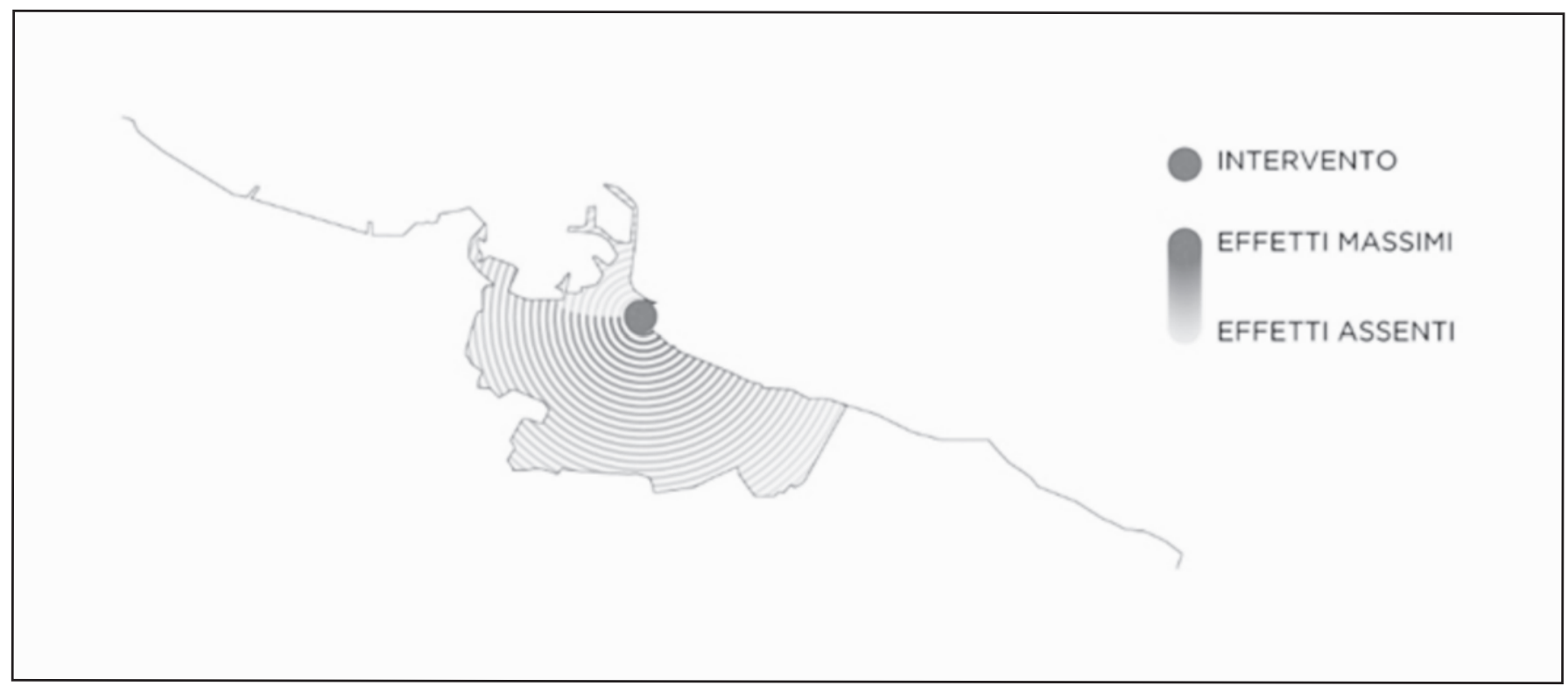

Figura 15 - Rappresentazione grafica degli effetti sui valori immobiliari generati dalla realizzazione del Polo del Contemporaneo nella fascia OMI centrale 


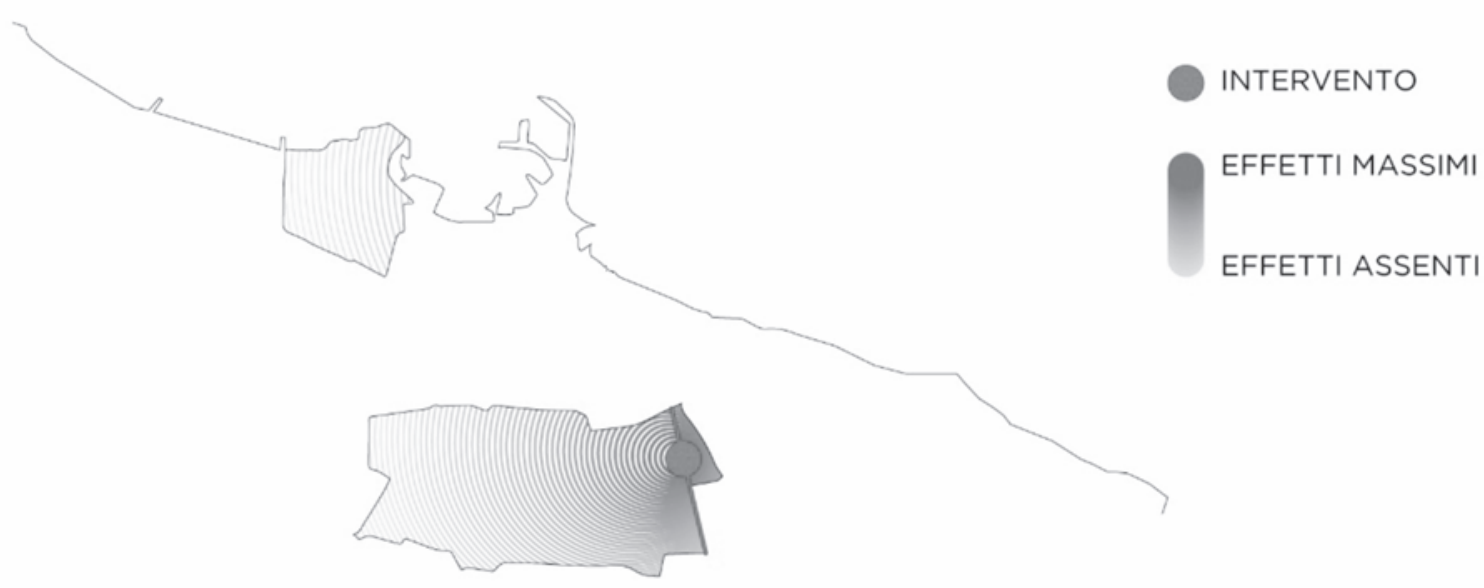

Figura 16 - Rappresentazione grafica degli effetti sui valori immobiliari generati dall'allargamento dell'asse viario di via Giovanni Amendola nella fascia OMI semicentrale

cazione, non si rilevano effetti in termini di variazione dei valori immobiliari: questa circostanza è connessa alla specificità del centro storico, caratterizzato da logiche mercantili e socio-economiche differenti rispetto a quelle del centro "Murattiano" della città, che tendono a neutralizzare gli effetti positivi della riqualificazione. L'incremento medio dei valori immobiliari registrato nella fascia OMI centrale è pari a circa $+6 \%$ : tale contributo attesta la rilevanza della realizzazione del Polo Contemporaneo sull'innalzamento del livello di qualità urbana percepita nella zona centrale in termini architettonici, sociali e dello spazio pubblico. II risultato appare coerente con l'andamento empirico atteso, giacché il progetto permette di migliorare le condizioni di vivibilità della zona. Tale fenomeno viene percepito dal mercato immobiliare di zona, attraverso l'apprezzamento di compendi a valenza storico-architettonica in grado di aumentare l'offerta culturale della città e di promuovere un maggior flusso di turisti.

Con riferimento alla fascia OMI semicentrale, il grafico di Figura 16 mette in risalto gli effetti dell'intervento di allargamento dell'asse viario di via Giovanni Amendola sui valori immobiliari delle abitazioni prossime al progetto, per i

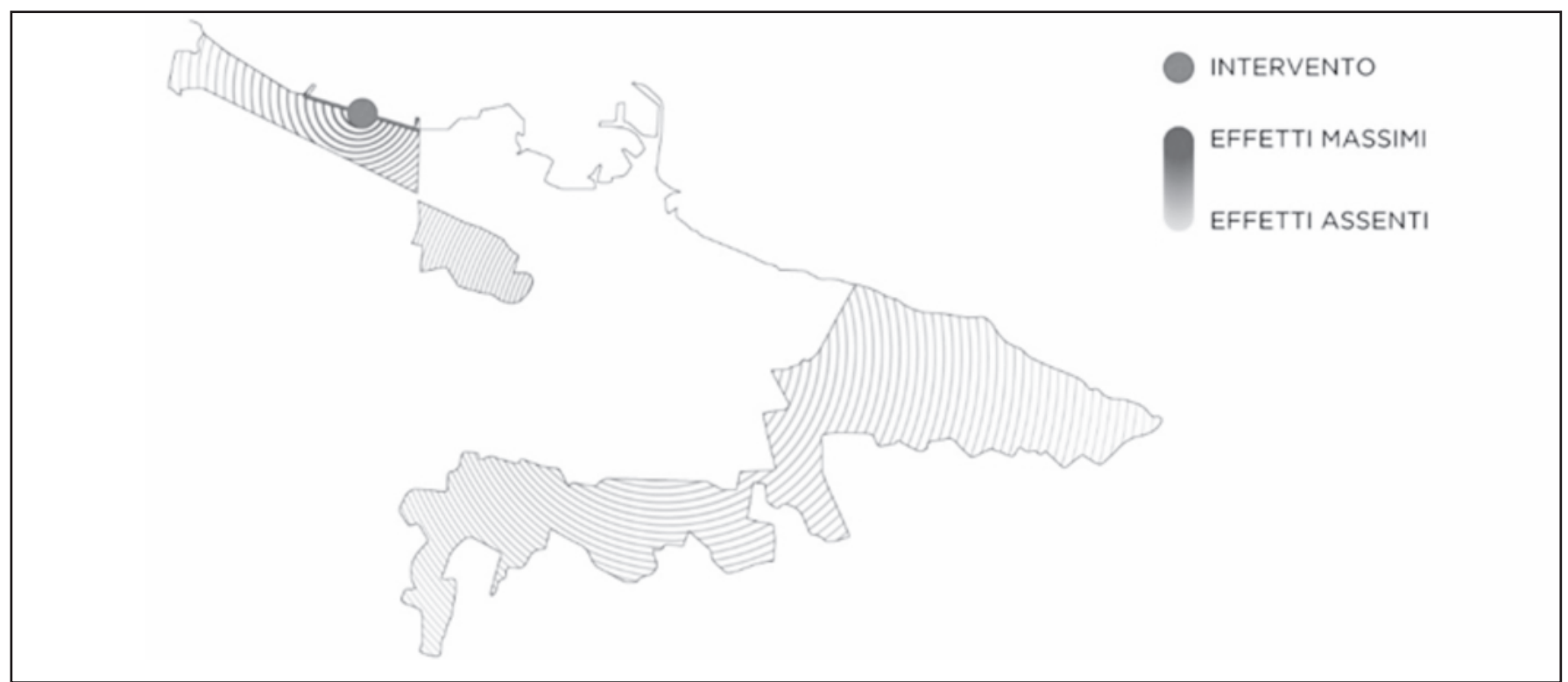

Figura 17 - Rappresentazione grafica degli effetti sui valori immobiliari generati dall'intervento di rigenerazione urbana del fronte mare di San Girolamo nella fascia OMI periferica 


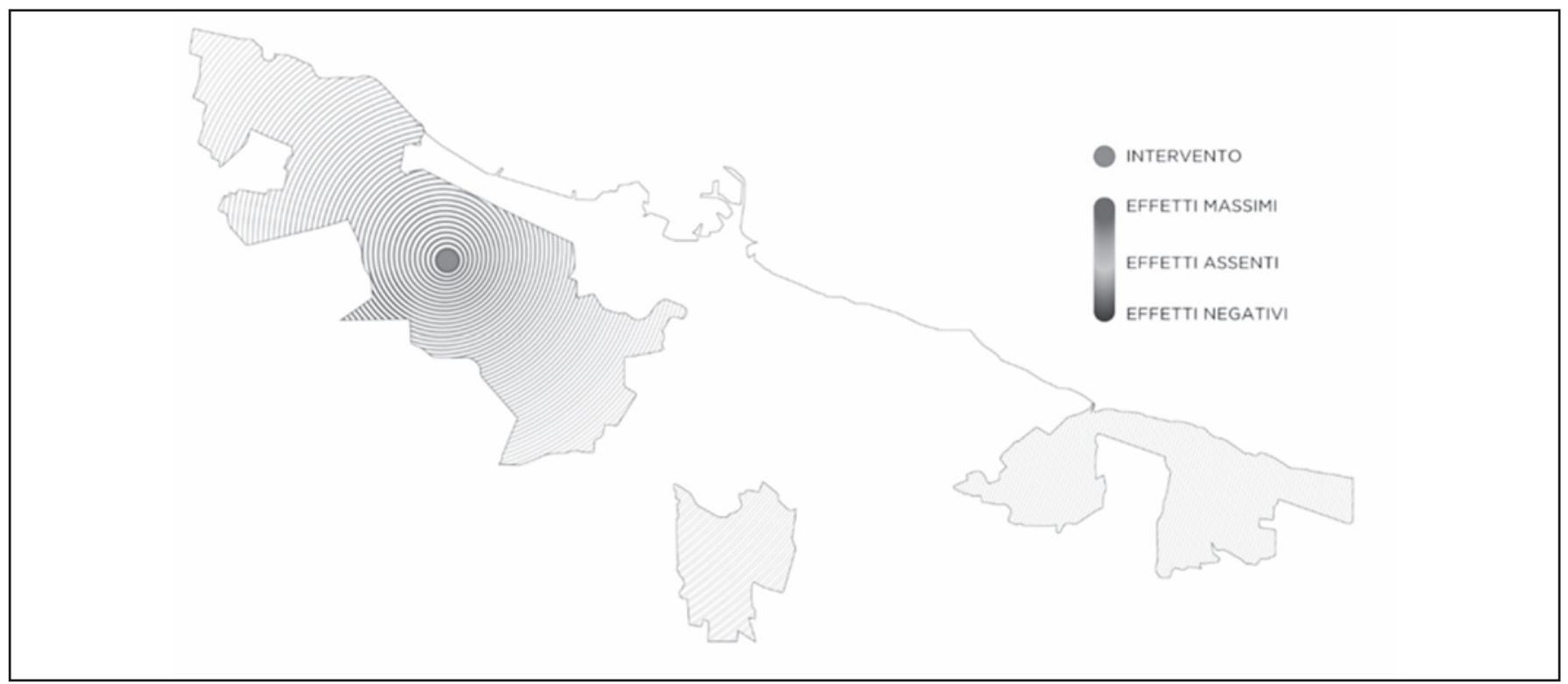

Figura 18 - Rappresentazione grafica degli effetti sui valori immobiliari generati dalla riqualificazione del Parco Giovanni Paolo II nella fascia OMI suburbana

quali si registra un incremento che varia tra $[+3 \%,+5 \%]$. Anche in questo caso, le ricadute mercantili tendono a sfumare all'aumentare della distanza dall'area di intervento.

Gli impatti sono nulli invece nell'area della fascia OMI semicentrale ad Ovest del centro urbano, eccessivamente distante dall'intervento in valutazione.

Per la fascia OMI periferica, i risultati ottenuti, rappresentati in Figura 17, mostrano un rilevante incremento dei valori immobiliari delle abitazioni prossime al fronte mare di San Girolamo oggetto della riqualificazione, attestando perciò gli impatti positivi che il progetto determinerebbe in termini di miglioramento del livello di qualità urbana nell'ambito di appartenenza. L'incremento medio di valori immobiliari è infatti pari a circa $+32 \%$, misura che evidenzia la cogenza del progetto di riqualificazione per questo ambito territoriale della città di Bari. Gli effetti di propagazione si annullano per gli immobili ubicati nelle porzioni della fascia periferica separate dal perimetro urbano in cui ricade l'area di intervento.

L'analisi di Figura 18 per la fascia OMI suburbana consente di identificare tre possibili scenari di variazione dei valori immobiliari nella situazione "post intervento":

i) un incremento significativo dei valori immobiliari, che interessa le abitazioni prossime al Parco Giovanni Paolo II;

ii) I'assenza di effetti per gli immobili maggiormente distanti dal progetto e per le abitazioni ubicate nelle zone della fascia OMI suburbana sconnesse dall'area in cui ricade il parco urbano oggetto di riqualificazione;

iii) un decremento dei valori immobiliari per le abitazioni a Sud-Ovest del progetto, prossime all'ospedale San Paolo e recentemente realizzate.
Lo scenario iii) riflette dunque un possibile spostamento della domanda di mercato dalla zona a Sud-Ovest dell'intervento verso le abitazioni prossime al Parco Giovanni Paolo II, che a seguito del progetto beneficerebbero, in termini di valori di mercato, di un'amenità a cui invece, allo stato attuale, si contrappone il degrado del parco.

L'incremento medio dei valori immobiliari per la fascia OMI suburbana è stimabile circa nel 1,4\%.

In Tabella 7 si riassumono le variazioni percentuali medie dei valori immobiliari nelle quattro fasce OMI della città di Bari a seguito dell'attuazione degli interventi di trasformazione urbana presi in esame.

Tabella 7 - Incrementi medi dei valori immobiliari a seguito della attuazione di ciascun intervento di trasformazione urbana e con riferimento a ciascuna fascia OMI

\begin{tabular}{|c|c|c|c|}
\hline \multicolumn{4}{|c|}{ FASCIA OMI } \\
\hline CENTRALE & SEMICENTRALE & PERIFERICA & SUBURBANA \\
\hline$+6 \%$ & $+0,6 \%$ & $+32 \%$ & $+1,4 \%$
\end{tabular}

\section{CONCLUSIONI}

L'obiettivo del lavoro ha riguardato la definizione e sperimentazione di un protocollo di valutazione ex ante degli effetti di interventi di trasformazione urbana sui valori immobiliari.

Il lavoro di ricerca si è concentrato su due tematiche di rilevante attualità: la prima è relativa alla qualità urbana; la seconda concerne il legame tra gli interventi di trasformazione, la qualità urbana e i valori immobiliari. Rispetto a queste due questioni, nella ricerca è stato proposto e testato un nuovo modello di valutazione della qualità urbana, 
basato sui punti di forza degli approcci metodologici correntemente impiegati per la valutazione della stessa.

La rifunzionalizzazione degli spazi urbani costituisce una delle più importanti e dibattute questioni nell'ambito delle politiche pubbliche di governo del territorio. Gli interventi di riqualificazione di aree degradate o dismesse permettono di riconvertire spazi urbani sottoutilizzati, ubicati in posizioni centrali e/o strategicamente rilevanti; di conferire "qualità" ad aree che sono fortemente compromesse; di valorizzare edifici in stato di fatiscenza; di dotare la città di nuovi luoghi per lo svago e per l'aggregazione sociale.

Nell'ambito dello studio sulla qualità urbana, è stato proposto un modello innovativo finalizzato a valutare in termini quantitativi le diverse componenti di qualità. Mutuando in parte la logica degli strumenti presenti nella letteratura scientifica di settore, il modello prevede la disarticolazione del concetto di qualità nelle sue parti costitutive e la successiva valutazione e quantificazione delle stesse tramite indicatori.

Con riferimento all'obiettivo del lavoro è stato definito un approccio metodologico operativo per l'analisi degli effetti degli interventi di trasformazione urbana in termini di variazione dei valori immobiliari. L'approccio sviluppato ha portato a generare un protocollo procedurale, articolato in fasi, con il quale si rende possibile catturare le ricadute della riqualificazione urbana sul mercato immobiliare. Questo strumento di supporto alle decisioni della Pubblica Amministrazione o degli investitori privati, è implementabile in qualsiasi contesto territoriale e per qualunque iniziativa di riqualificazione. In particolare, il protocollo potrà essere impiegato nelle fasi preliminari della progettazione di interventi di riqualificazione urbana per i) verificare gli effetti di differenti progetti proposti in termini di valori immobiliari ed, eventualmente, ricalibrare la soluzione progettuale da attuare; ii) comparare alternative progettuali diverse ai fini della scelta della soluzione "migliore"; iii) orientare la progettazione di opere pubbliche e/o a servizio della collettività verso iniziative la cui portata rigeneratrice prevista sia maggiore; iv) supportare le negoziazioni, in caso di iniziative da attuare in partenariato pubblico-privato. Nella presente ricerca, la verifica delle ricadute generate dalla riqualificazione è stata indagata studiando la variazione dei valori immobiliari delle fasce OMI del mercato immobiliare prima e dopo l'attuazione dell'intervento.

La sperimentazione del protocollo è avvenuta sulla città di Bari (Sud Italia). In primo luogo, sono stati selezionati quattro interventi di trasformazione urbana in corso di realizzazione, ciascuno appartenente a una delle quattro fasce urbane (centrale, semicentrale, periferica e suburbana) individuate dall'OMI dell'Agenzia delle Entrate. Per ciascuna fascia, è stato rilevato un campione di immobili recentemente compravenduti, di prezzo e caratteri noti. La procedura econometrica implementata ha permesso di ottenere una funzione del prezzo generalizzata, ovvero valida per l'intero territorio comunale di Bari, in grado di identificare il miglior set di variabili che influenzano la for- mazione dei valori immobiliari nelle situazioni "ante" e "post intervento". II principale vantaggio della tecnica adoperata concerne la capacità di generare modelli descrittivi dei meccanismi di formazione dei prezzi immobiliari, caratterizzati da una elevata attendibilità statistica ed al tempo stesso da correlazioni funzionali facilmente interpretabili, evitando di costituire delle "black boxes" di difficile comprensione per i possibili utenti. È evidente che le potenzialità descrittive e predittive dei modelli ottenuti dipendono significativamente dalla dimensione dei campioni di studio: laddove infatti il database risultasse contenuto, la procedura utilizzata potrebbe non riuscire a generare output sufficientemente affidabili.

Il protocollo valutativo sviluppato potrà affiancare gli strumenti di verifica della fattibilità finanziaria ed economica dei progetti correntemente impiegati, ponendosi come un ulteriore supporto alle decisioni per gli operatori pubblico e privato. Nelle operazioni condotte in partenariato pubblico-privato, I'approccio metodologico illustrato potrà guidare nella selezione dei progetti che prevedono, in primis, un innalzamento del livello di qualità urbana e, in secundis, un incremento dei valori immobiliari attesi. Quest'ultima condizione permette di identificare le iniziative alle quali competono ricadute anche dal punto di vista fiscale, in quanto ad un valore immobiliare superiore corrispondono in generale maggiori entrate per la finanza pubblica.

Il protocollo procedurale proposto si contraddistingue per la flessibilità e la ripercorribilità delle fasi in cui si articola, consentendo il costante monitoraggio dei diversi step e I'adattamento a differenti input che dovessero derivare da evoluzioni del contesto di riferimento: la possibilità di adeguare la successione delle azioni da condurre alle caratteristiche di diversi ambiti territoriali permette di applicare il protocollo anche ad altri aspetti della qualità urbana, come quello relativo alla salute e, più in generale, alla qualità ambientale, alla presenza di percorsi pedonali e/o di piste ciclabili. Tali modifiche potranno essere proposte dagli amministratori pubblici, dagli operatori del mercato di riferimento e dalle comunità locali in ragione dei caratteri delle aree urbane oggetto di riqualificazione e dei progetti di riconversione analizzati.

Il lavoro si pone in un filone di ricerca ampio e di assoluta attualità. La tematica della riqualificazione urbana, intesa come rilancio di aree urbane degradate e di valorizzazione del patrimonio immobiliare esistente pubblico e privato, costituisce, infatti, una questione in costante evoluzione nell'ambito delle politiche di governo che, legata alle scarse disponibilità finanziarie delle Pubbliche Amministrazioni, rende necessaria un'attenta ed adeguata selezione degli interventi da attuare.

Futuri sviluppi della ricerca potranno riguardare I'analisi degli effetti sinergici degli interventi realizzati in una specifica fascia OMI sulle altre fasce e, più in generale, sulI'intero sistema urbano. Così affinato, lo strumento potrà costituire un valido supporto anche per la ridefinizione e l'aggiornamento dei perimetri delle fasce di mercato OMI a valle di interventi di riqualificazione urbana. 
* Felicia Di Liddo, Dipartimento di Scienze dell'Ingegneria Civile e dell'Architettura, Politecnico di Bari, Bari email: felicia.diliddo@poliba.it

** Pierluigi Morano, Dipartimento di Scienze dell'Ingegneria Civile e dell'Architettura, Politecnico di Bari, Bari email: pierluigi.morano@poliba.it

*** Francesco Tajani, Dipartimento di Architettura e Progetto - Università La Sapienza di Roma, Roma email: francesco.tajani@uniroma1.it

**** Carmelo Maria Torre, Dipartimento di Scienze dell'Ingegneria Civile e dell'Architettura, Politecnico di Bari, Bari email: carmelomaria.torre@poliba.it

\section{Ringraziamenti}

Gli autori ringraziano il Dott. Gianni Guerrieri, Direttore Centrale dell'Osservatorio del Mercato immobiliare (OMI) e Servizi Estimativi dell'Agenzia delle Entrate, per i dati forniti, impiegati per le analisi elaborate e illustrate nel presente lavoro.

\section{Bibliografia}

AA.VV., Monitoraggio della rigenerazione urbana attraverso indicatori condivisi, Venezia: AUDIS, 2010.

Adair A., Berry J., Mcgreal S., Deddis B., Hirst S., The financing of urban regeneration, Land Use Policy, Vol.17, No. 2, 2000, pp.147-156.

AgNOletTI C., BocCl C., Gli effetti economici e distributivi degli interventi di riqualificazione urbana, Atti del XVII Congresso nazionale Associazione Italiana di Valutazione - AIV -, Napoli, 10-11 Aprile 2014.

Associazione Aree Urbane Dismesse (Audis), Carta Audis della rigenerazione urbana, 2008 (scaricabile dal sito internet: http://www.audis.it/)

Associazione Aree Urbane Dismesse (Audis), I/ Protocollo della qualità di Roma Capitale. Definire e valutare la qualità dei progetti urbani complessi, Roma Capitale, Risorse per Roma, 2012.

Beinat E., NiJKamp P. (Eds.), Multicriteria analysis for landuse management, Vol. 9, Springer Science \& Business Media, 1998.

Berardi L., KaPelan Z., "Multi-case EPR strategy for the development of sewer failure performance indicators", in World Environmental and Water Resources Congress 2007: Restoring Our Natural Habitat, Florida (USA), 2007, pp. 1-12.

BoICE R.L., Discounted cash flow analysis and long-term leases, The Appraisal Journal, Vol. 67, No. 2, 1999, pp. 153-156.

Bonaiuto M., Fornara F., Bonnes M., Indexes of perceived residential environment quality and neighbourhood attachment in urban environments: a confirmation study on the city of Rome, Landscape and urban planning, Vol. 65, No. 1-2, 2003, pp. 41-52.

Bottero M., Datola G., Monaco R., Fuzzy Cognitive Maps: un approccio valutativo dinamico per la valutazione dei processi di rigenerazione urbana, Valori e Valutazioni, Vol. 23, pp. 77-90.
Bourassa S., Hoesli M., Peng V.S., Do housing submarkets really matter?, Journal of Housing Economics, Vol. 12, No. 1, 2003, pp. 12-28.

Brzozowska K., Cost-benefit analysis in public project appraisal, Engineering economics, Vol. 3, No. 53, 2007, pp. 78-83.

Clark D.E., KAHN J.R., The social benefits of urban cultural amenities, Journal of regional science, Vol. 28, No. 3, 1988, pp. 363-377.

$\mathrm{D}^{\prime} \mathrm{ACCl}$ L., Formazione e simulazione dei valori immobiliari (Tesi di Dottorato, Politecnico di Torino), 2007.

D'ACCI L., "Spatial distribution of social benefit given by urban attractions: A test of UrAD model", in International Conference on Computational Science and Its Applications, Springer, Berlin, Heidelberg, 2009, pp. 237-252.

$\mathrm{D}^{\prime} \mathrm{ACCl}$ L., Monetary, subjective and quantitative approaches to assess urban quality of life and pleasantness in cities (hedonic price, willingness-to-pay, positional value, life satisfaction, isobenefit lines), Social Indicators Research, Vol.115, No. 2, 2014, pp. 531-559.

DAS D., Urban quality of life: $A$ case study of Guwahati, Social Indicators Research, Vol. 88, No. 2, 2008, pp. 297-310.

Farinelli V., Gabrielli L., Ville Venete - L'analisi multicriteri nel processo decisionale per la stima, Recupero e Conservazione, Vol. 133, No. 1, 2016, pp. 1-8.

Figueira J., Greco S., Ehrgott M. (Eds.), Multiple criteria decision analysis: state of the art surveys, Springer Science \& Business Media, Vol. 78, 2005.

Fornara F., BonaIUTO M., BONnes M., Indicatori di qualità urbana residenziale percepita (IQURP). Manuale d'uso di scale psicometriche per scopi di ricerca e applicativi, Franco Angeli, Milano, 2010.

Fregonara E., Coscia C., Multi criteria analyses, life cycle approaches and delphi method: A methodological proposal to assess design scenarios | [Analisi multi 
criteria, approcci life cycle e delphi method: Una proposta metodologica per valutare scenari di progetto], Valori e Valutazioni, Vol. 23, 2019, pp. 107-117.

FrenCH N., Gabrielli L., Discounted cash flow: accounting for uncertainty, Journal of Property Investment \& Finance, Vol. 23, No. 1, 2005, pp. 75-89.

Gabrielli L., BotTARell M., Financial and economic analysis for ground-coupled heat pumps using shallow ground heat exchangers, Sustainable Cities and Society, Vol. 20, 2016, pp. 71-80.

Giustolisı O., Berard L., Pipe level burst prediction using EPR and MCSEPR. Water Management Challenges in Global Change, 2007, pp. 39-46.

Giustolısı O., SAvic D., Advances in data-driven analyses and modelling using EPR-MOGA, Journal of Hydroinformatics, Vol. 11, 2009, pp. 225-236

Giustolisı O., Savic D., A symbolic data-driven technique based on evolutionary polynomial regression, J Hydroinform, Vol. 8, No. 3, 2006, pp. 207-222.

GoldberG D.E., Genetic Algorithms in Search, Optimization, and Machine Learning. Addison Wesley. Reading, MA, 1989.

Guarini M.R., D’addabbo N., Morano P., Tajani F., Multicriteria analysis in compound decision processes: the AHP and the architectural competition for the chamber of deputies in Rome (Italy), Buildings, Vol. 7, No. 2, 2017, p. 38.

Guarinı M.R., Battisti F., Chiovitti A., Public initiatives of settlement transformation: A theoretical-methodological approach to selecting tools of multi-criteria decision analysis, Buildings, Vol. 8, No. 1, 2018, p. 1.

Hall P., "Towards a general urban theory", in Brotchie G.F., Batty M., Blakley E., Hall P. (Eds.), Cities in Competition: Productive and sustainable cities for the 21st century, Longman, Melbourne, pp. 3-31.

Hardy M.A., Regression with Dummy Variables, Sage Publications, No. 93, 1993.

Helfert Eric A., Financial analysis tools and techniques: a guide for managers, McGraw-Hill, New York, 2001, pp. 221-296.

Herbohn J.L., HaRrisOn S.R., "Introduction to discounted cash flow analysis and financial functions in EXCEL", in Harrison S. R., Herbohn J. L., Mangaoang E., Vanclay J, Socio-Economic Research Methods in Forestry: A Training Manual, Rainforest CRC, Cairns, 2002, pp. 109118.

KISHORE R., Discounted cash flow analysis in property investment valuations, Journal of Property Valuation and Investment, Vol. 14, No. 3, 1996, pp. 63-70.

Kort M., Klijn E.H., Public-private partnerships in urban regeneration projects: organizational form or managerial capacity?, Public Administration Review, Vol. 71, No. 4, 2011, pp. 618-626.

Lambiri D., Biagi B., Royuela V., Quality of life in the economic and urban economic literature, Social Indicators Research, Vol. 84, No. 1, 2007, p. 1.

LAYARD P.R.G., Cost-benefit analysis, Cambridge University Press, 1994.

LiChField N., Cost-Benefit Analysis in urban redevelopment, 1962.

lora E., Powell A., Van Praag B.M., Sanguinetti P. (Eds.), The quality of life in Latin American cities: Markets and perception, The World Bank, 2010.

LuDLOW D., Ensuring quality of life in Europe's cities and towns. Tackling the environmental challenges driven by European and global change. European Environment Agency, Report No 5/2009, 2009.

LyNCH A.K., Rasmussen D.W., Proximity, neighbourhood and the efficacy of exclusion, Urban Studies, Vol. 41, No. 2, 2004, pp. 285-298.

MARGLIN S.A., Approaches to dynamic investment planning, Amsterdam, North-Holland, 1963.

Morano P., Rosato P., Tajani F., Manganelli B., Di Liddo F., Contextualized Property Market Models vs. Generalized Mass Appraisals: An Innovative Approach, Sustainability. Vol. 11, No. 18, 2019, p. 4896.

Morano P., TAJANI F., LoCURCIO M., Land use, economic welfare and property values: an analysis of the interdependencies of the real-estate market with zonal and socio-economic variables in the municipalities of Apulia region (Italy), International Journal of Agricultural and Environmental Information Systems (IJAEIS), Vol. 6, No. 4, 2015, pp. 16-39.

Morano P., TAjani F., Locurcio M., Multicriteria analysis and genetic algorithms for mass appraisals in the Italian property market, International Journal of Housing Markets and Analysis, Vol. 11, No. 2, 2018, pp. 229-262.

Morano P., TAJANI F., Guarini M.R., Di LidDo F., Iniziative di riqualificazione urbana in partenariato pubblicoprivato: un modello per la definizione di liste di priorità temporale, Laborest, No. 20, 2020.

MuNDA G., Social multi-criteria evaluation for a sustainable economy, Vol. 17, Berlin, Springer, 2008.

Nijkamp P., Rietveld P., Voogd H., Multicriteria evaluation in physical planning, Vol. 185, Elsevier, 2013.

RichaRdS R., O'LEARY B., MutSONZIWA K., Measuring quality of life in informal settlements in South Africa, Social indicators research, Vol. 81, No. 2, 2007, pp. 375-388.

ROGERSON R.J., Quality of life and city competitiveness, Urban Studies, Vol. 36, No. 5-6, 1999, pp. 969-985.

Rosato P., Un modello di analisi multicriteri per la localizzazione di infrastrutture lineari in aree ad insediamento diffuso, Aestimum, No. 36, 1999.

Rosato P., Breil M., Giupponi C., \& Berto R., Assessing the impact of urban improvement on housing values: a hedonic pricing and multi-attribute analysis model for the historic Centre of Venice, Buildings, Vol. 7, No. 4, 2017, 112. 
Sassone P.G., Schaffer W.A., Cost-benefit analysis: $A$ handbook, New York: Academic Press, Vol. 182, 1978.

Savic D.A., Giustolisı O., Laucellı D., Asset deterioration analysis using multiutility data and multi-objective data mining, Journal of Hydroinformatics, Vol. 11, No. 3-4, 2009, pp. 211-224.

ShIN D.C., RutKowski C.P., PARK C.M., The quality of life in Korea: Comparative and dynamic perspectives, Social Indicators Research, Vol. 62,63, 2003, pp. 3-36.
Tajani F., Morano P., Locurcio M., D'addabbo N., "Property valuations in times of crisis: artificial neural net-works and evolutionary algorithms in comparison", in International Conference on Computational Science and Its Applications, Springer, Cham, 2015, June, pp. 194-209.

\section{Riferimenti internet}

GeOpol_Omı - Agenzia del Territorio, Agenzia delle Entrate, http://www.agenziaentrate.gov.it/ 